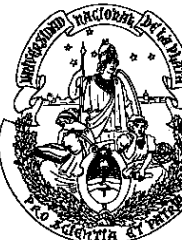

MAESTRIA EN DERECHOS HUMANOS

FACULTAD DE CIENCIAS JURIDICAS Y SOCIALES

UNIVERSIDAD NACIONAL DE LA PLATA

\title{
TESIS DE MAESTRIA
}

TITULO: Infancias como Colectividades Bivalentes. Una mirada etnográfica sobre las representaciones sociales del "interés superior del niño/a" en contexto de encierro.

AUTORA: Abog. Lorena Ríos

DIRECTORA DE TESIS: Mgs. Olga G. Brunatti

La Plata - Diciembre 2016 


\section{Agradecimientos}

El presente trabajo es el resultado de un proceso de crecimiento tanto personal como académico y la finalización de una etapa que si bien supo angustiarme, hoy la concibo con la tranquilidad de haber realizado un trabajo con compromiso y responsabilidad, acompañada fundamentalmente por Olga, mi directora de tesis, a quien le agradezco no solo la bondad con que compartió sus enormes conocimientos sino también la calidez humana con la que cuenta.

Agradezco profundamente a Mauro, compañero de grandes momentos, por sus agudas intervenciones.

A Valentina, Santiago y Matías que me enseñan todos los días a crecer a su lado.

A mis hermanos Valeria y Diego y a mis padres, Marta y Oscar, por ser incondicionales.

A mis amigas que en los momentos más difíciles me alentaron a continuar en este camino.

A mis compañeros y compañeras de trabajo por "bancarme" en este recorrido.

Al equipo de la UACJ por el amplio espacio de debate y discusión que genera y por haber sido el disparador para la elección de la temática de esta tesis.

A todas y todos los informantes "privilegiados" quienes hicieron posible la realización de esta tesis, especialmente a las mujeres madres de la Unidad 33. 


\section{RESUMEN}

La presente investigación etnográfica, realizada en el marco de la Maestría de Derechos Humanos de la UNLP, es el producto de un proceso de indagación motivado por el propósito de desentrañar y comprender los diferentes sentidos dados al “interés superior del niño/a" en un contexto de encierro como lo es la Unidad Penitenciaria 33 de La Plata.

En este recorrido, el objeto de estudio se centró en el análisis de los significados dados a las infancias previos y posteriores al cambio de paradigma de "protección integral" sobre la infancia en la Argentina y como dichos significados orientaron los discursos y prácticas de los actores de este estudio. He identificado las concepciones que sobre las infancias desde el punto de vista del nativo subyacen en la Unidad Penitenciaria 33 de La Plata durante el período 2014-2015 en el que realicé el trabajo de campo, estableciendo la vinculación de esas concepciones con sus prácticas.

Para ello realicé un estudio cualitativo utilizando diversas técnicas metodológicas como observación participante, entrevistas semiestructuradas y en profundidad, que permitieron acercarme a los diversos procesos de construcción de subjetividades relatados por los/as protagonistas de las historias que surgieron durante el proceso de investigación.

Entre los principales resultados de mi investigación establecí que los sentidos diferenciales que le otorgan los actores al "Interés Superior del Niño/a", generan que el mismo se convierta en un principio sujeto a la discrecionalidad de quien lo pone en práctica, manteniéndose de ese modo las mismas prácticas minorizantes que se quisieron dejar atrás con el tan esperado cambio de paradigma. La infancia leída en clave de colectividad bivalente fue lo que me permitió desentrañar los sentidos dados a la "niñez encarcelada" junto a sus madres: mujeres detenidas que se amoldan a la idea natural de maternidad. Todos ellos, ejes que fueron desarrollados en un contexto de encierro por lo que fue fundamental para llegar a dichos resultados, entender la lógica carcelaria a través del tejido de relaciones sociales que allí se conforman. 


\section{INDICE}

Introducción . ........................................................... 1

De "Indefensas criaturas" a Colectividades bivalentes ..................................... 2

Estado de la cuestión ........................................................................................ 3

Aspectos metodológicos ................................................. 7

Ingreso al campo .................................................. 7

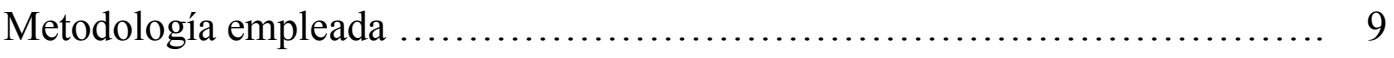

Plan de trabajo $\ldots \ldots \ldots \ldots \ldots \ldots \ldots \ldots \ldots \ldots \ldots \ldots \ldots \ldots \ldots \ldots \ldots \ldots \ldots \ldots, \quad 10$

Capítulo 1. La Unidad Penitenciaria no 33 de La Plata ....................... 12

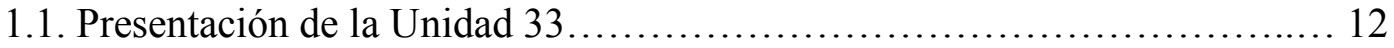

1.2. Actores en escena. La organización funcional.......................... 13

1.3. El "Consejo Asistido". Censor de la maternidad y la crianza. ............. 16

1.4. Mujeres detenidas en la Unidad 33 y su relación con los actores involucrados en el proceso judicial ................................... 18

1.5. Otras Instituciones vinculadas con la Unidad. ....................... 20

1.5.1. El Centro de Orientación y Asistencia para Familiares

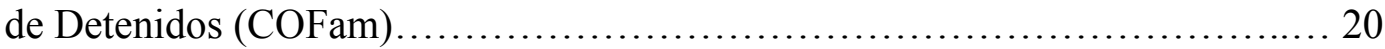

1.5.2. El Jardín Maternal. .................................................. 20

1.6 Miradas, tramas y tensiones. Los sentidos otorgados a la

Unidad 33 desde la perspectiva de sus actores ........................... 21

1.7. Ellas y "Nosotros". La finalidad del encierro.......................... 28

1.8. La discriminación subrepticia. Menores a la cárcel, niños y niñas

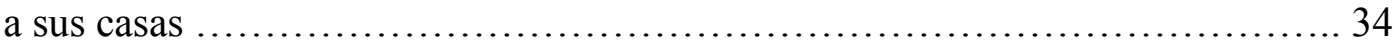

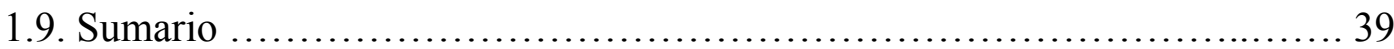

Capítulo 2. Las infancias: lectura en clave de colectividades bivalentes .......... 40

2.1. Porque hablar de infancias ....................................... 40

2.2. La condición postsocialista y las luchas por el reconocimiento..............44

2.3. De la situación irregular a la protección integral ........................ 47

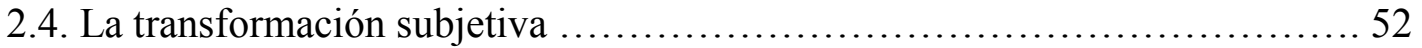

2.5. De los "menores" de ayer a los "niños" de hoy ........................... 55

2.6. Sumario ........................................................... 62

Capítulo 3. Representaciones sociales sobre el interés superior del niño/a. ........63 
3.1. El interés superior del niño en un contexto carcelario ......................6 63

3.2. La naturalización del rol materno en la norma ........................... 68

3.3. El ejercicio de la maternidad en contexto. La construcción

de buenas y malas madres ........................................... 72

3.4. Los discursos de verdad. El saber médico ............................. 80

3.5. Sumario .......................................................... 86

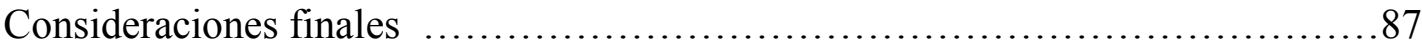

Bibliografía .......................................................... 90 


\section{INTRODUCCIÓN}

"Para que la visión de la Convención se convierta en una realidad para todos los niños se necesitarán soluciones innovadoras, un importante aumento de los recursos y la voluntad política para invertir en los niños y hacer que su bienestar ocupe el centro de la agenda política, económica y social."

(Mensaje del Secretario General de las Naciones Unidas con ocasión del Día Universal del Niño/a, 2014).

La consagración de los derechos de la infancia en la Convención Internacional sobre los Derechos del Niño/a (CDN de aquí en más) y el cambio de paradigma planteado a partir de ella, posibilitó que la mirada sobre la niñez, puesta hasta ese momento en los "menores" con determinadas "carencias", se ampliara, regulándose los derechos para toda "la" infancia.

Sin embargo, la consagración de derechos en la norma no es sinónimo de ejercicio de los mismos. Acuerdo con Otano (2000) en el análisis que realiza sobre la tensión existente entre el objetivo de los instrumentos internacionales que buscan garantizar el respeto por los derechos humanos y la subsistencia de diferentes formas de discriminación cristalizadas en prácticas y representaciones de los actores sociales. Esta tensión conlleva al enfrentamiento de los seres humanos en razón de sus diferencias de género, etarias, étnicas, raciales y/o religiosas, entre otras.

Fue en la Unidad Penitenciaria 33 de La Plata en donde encontré un ejemplo claro de esa tensión existente entre teoría y práctica. Así es como comencé a preguntarme qué sentidos le otorgaban al interés superior del niño/a y al ejercicio de sus derechos, los distintos actores que se relacionaban con los niños/as en situación de encierro junto a sus madres en dicha Unidad y surgió la principal pregunta que guía esta investigación, esto es, cuáles son las representaciones sobre el interés superior del niño/a y sobre el ejercicio de los derechos de los mismos en el encierro, que construyen los diferentes actores (mujeres madres, personal penitenciario, funcionarios judiciales y docentes de la institución educativa a la que concurren los mismos).

A su vez, dicha pregunta me llevó a otros interrogantes solidarios con la primera y más general pregunta de investigación: ¿A qué infancia refiere la CDN y 
cómo es resignificada?, ¿existe una definición intercultural de infancia?, ¿ante qué conflictos se pone en acción el interés superior del niño/a?, ¿de qué modos se expresan dichos conflictos?

Si bien mi interés en un principio estaba dirigido a la construcción de subjetividades de niños y niñas en el encierro, a lo largo de la investigación comprendí que el trabajo no podía desconocer los modos de construcción de la maternidad en dicho contexto. En ese sentido como sostiene Villalta (2013), el término complementario que corresponde al de hijo es el de padres y fundamentalmente el de madres. Es así como la ley de ejecución penal de la nación estableció que "La interna podrá retener consigo a sus hijos menores de cuatro años. Cuando se encuentre justificado, se organizará un jardín maternal a cargo de personal calificado." y similar normativa en la Provincia de Buenos Aires estableció que "A fin de privilegiar la relación materno infantil en los lugares donde se alojen madres que convivan con hijos y en los casos en que el Servicio Penitenciario Bonaerense cuente con dichos establecimientos, se formará un Consejo asistido”.

De este modo el sistema penal dio una respuesta a un "problema social" posibilitando la permanencia de niños y niñas en situación de encierro, poniendo en jaque el principio del "interés superior del niño/a". Parto entonces de este "problema" a partir del cual propongo en este trabajo realizar un análisis crítico a través de la categoría analítica "colectividad bivalente", la cual me permitió dar un contexto teórico al tema que aquí desarrollo.

\section{De "Indefensas criaturas" a Colectividades bivalentes}

He encontrado en la conceptualización de la categoría analítica "colectividad bivalente", el término adecuado para estudiar las representaciones construidas con relación a los niños/as en contexto de encierro. A lo largo de la investigación los niños/as fueron identificados a través de las categorías nativas "indefensos" y "criaturas" como carenciados, incompletos, en definitiva como "objetos" de protección. A su vez, en general, se los identificó como provenientes de familias con bajos recursos económicos. En razón de ello, fueron estas categorías nativas las que guiaron mi encuentro con la categoría analítica colectividad bivalente, construida por Fraser. (1997). 
Tomaré la definición dada por la autora respecto a dicha categoría como aquellos grupos que además de luchar por el reconocimiento de una identidad cultural deben luchar por la igualdad social. Se trata de colectividades económicamente desplazadas y culturalmente menospreciadas. Estas injusticias, explica Fraser, no pueden entenderse como un efecto indirecto una de la otra, sino que ambas son primarias y co-originarias. A lo largo de su trabajo identifica dos colectividades bivalentes paradigmáticas: el género y la "raza", las cuales, sostiene, necesitan indefectiblemente tanto soluciones de redistribución como de reconocimiento. Es desde esta construcción que desarrolla Fraser que me he permitido pensar a la infancia como una colectividad bivalente.

Sintetizando, es a partir de la categoría colectividad bivalente desde la cual propongo reflexionar sobre el "problema social" de las infancias en situación de encierro.

\section{Estado de la cuestión}

Apuntar a conocer los modos en que se significa el interés superior del niño/a en un contexto de encierro me llevó a indagar en los modos de construcción de "la" infancia, maternidad y crianza, tanto como, en los procesos de subjetivación que dan sentido a la niñez "encarcelada" en la Unidad 33 de La Plata. En ese camino varios fueron los antecedentes teóricos que guiaron esta tesis a través de distintas propuestas académicas abordadas desde diversas disciplinas y vinculadas a diferentes temáticas como la desnaturalización de categorías infancia y maternidad; interés superior del niño/a y derechos humanos; "menores abandonados/delincuentes"; poder y prácticas divisorias e investigaciones sobre mujeres madres en prisión.

Desde la antropología, una de las autoras que problematiza la categoría de niñez es Szulc (2006). Su lectura resultó ser un gran aporte para desnaturalizar dicha categoría entendida desde el sentido común contemporáneo de un modo natural, ahistórico y homogéneo. Ya a comienzos del S. XX, la antropóloga Margaret Mead (1990) había cuestionado el carácter universal y natural de las categorías de la adolescencia, demostrando cuán flexible y sensible a las influencias culturales es la naturaleza humana. En el marco de la misma disciplina he rescatado los trabajos de Colangelo (2014) quien pone en interdicción la universalidad de la crianza en función 
de los desafíos que se presentan ante la diversidad sociocultural en las prácticas de atención en los controles o consultas pediátricas. En otro de sus trabajos Colangelo (2003) argumenta cómo la mirada desde otras disciplinas, particularmente la antropología, puede aportar al estudio de las intervenciones pedagógicas sobre la infancia. Dicha lectura me hizo reflexionar sobre los aportes que realiza esta disciplina, a través de la mirada del otro, en las diferentes intervenciones relacionadas con la infancia. Desde la historia fue Ariès ([1960] 1987) quien ubicó a la infancia como una construcción histórica de la modernidad, desde ese momento el niño deja de ser visto como un pequeño adulto y se lo comienza a caracterizar como personas inacabadas, carentes, necesitadas de cuidado y protección, encontrando en la escuela y la familia los espacios fundamentales para ello. Otro antecedente importante que contribuyó a la posibilidad de hablar de infancias en plural fue el trabajo de Carli (1999) quien si bien expresa que no hay que dejar de hablar de infancias en plural, hoy existen determinados fenómenos que puede afirmarse, son comunes a todas las infancias. Los cambios en las estructuras familiares, las tecnologías, el atravesamiento del mercado y de los medios de comunicación hacen que la construcción histórica de la infancia, centrada en la familia, la escuela y el estado, ya no resulte tan eficaz para diferenciar la infancia de la adultez, fenómenos todos que no resultaron ser ajenos a la temática abordada en la presente investigación y que coadyuvaron al análisis de la misma.

También con relación a los roles sociales asignados a las mujeres y sobre las representaciones de las familias han sido de mucha utilidad lecturas como las de Badinter (1981) quien pone en discusión el amor maternal como instinto proveniente de la "naturaleza femenina". La autora desmitifica el sentido natural e instintivo del amor materno, luego de un recorrido a través de los siglos XVII al XX que evidencia que el amor materno se debe a un comportamiento social e histórico que se modifica según épocas. En antropología son vastas las discusiones respecto de la relación familiar, parentesco y unidades domésticas. Si bien no profundizaré en dichas discusiones rescato por un lado, los aportes de los trabajos de Schneider (1972) y Collier, Rosaldo y Yanagisako (1997) quienes discuten la herencia funcionalista, a la vez que señalan que la representación biológica del parentesco continuaría prevaleciendo en la construcción de conceptos que orientan algunas investigaciones sobre el tema. Por el otro lado, es de suma importancia la propuesta de Bourdieu ([1994] 1997) sobre el discurso que la familia produce acerca de sí misma en tanto principio de visión y división común que 
todos tenemos in mente a partir de su incorporación en el proceso de socialización. No puedo dejar de mencionar en la presente investigación los atravesamientos de género que propone Butler (2007), quien ofrece una lectura considerada por el movimiento feminista como fundamental para el conocimiento de la teoría feminista actual.

Desde el pensamiento filosófico, la discusión sobre el sujeto y el poder de Foucault (1988) es un antecedente más que significativo para analizar cómo se teje la malla social atravesada por relaciones de poder múltiples. En esta tesis resulta un referente importante en el análisis de las prácticas cotidianas y relaciones sociales que están presentes en el referente empírico elegido. Tal como sostiene Foucault las prácticas divisorias, el hombre "normal" y "anormal", nace con el saber del hombre, este saber que se desprende de las prácticas sociales de control y vigilancia, prácticas que se visualizan en el presente trabajo de investigación.

Con relación a la conceptualización de derechos humanos, esta tesis se enmarca en las teorías críticas sobre los mismos que plantean tanto de Sousa Santos (2010) como Herrera Flores (2008). De Sousa Santos ubica a los derechos humanos en una casi permanente tensión entre lo regulatorio y la emancipación social, afirmando que actualmente se está viviendo una doble crisis social simbolizada por la crisis del Estado regulador y por la crisis de la revolución y el reformismo social. A su vez Herrera Flores sostiene que los derechos humanos son "procesos; es decir, el resultado, siempre provisional, de las luchas que los seres humanos ponen en práctica para poder acceder a los bienes necesarios para la vida." (Herrera Flores, 2008:22). Cuando Herrera Flores (op. cit.) refiere a bienes necesarios para la vida está haciendo alusión a los bienes tanto materiales como inmateriales (educación, vivienda, trabajo, medio ambiente) que se han ido consiguiendo a través de luchas sociales a lo largo de la historia. El porqué de esas luchas, explica el autor, se corresponden con la necesidad de acceder a esos bienes a los que no todos y todas tienen el mismo acceso, dados los procesos de división del hacer humano: división social, sexual, étnica y territorial. En esta investigación cabría sumar otros procesos de división que se intersectan con los mencionados, esto es, de género y etarios. Asimismo, para conocer cómo se instalan los derechos humanos en el nuevo escenario histórico político luego de la caída del Muro de Berlín, lecturas como las de Rifiotis (2013) y Fraser (1997) han sido clarificantes para entender la nueva dinámica de los movimientos sociales y las luchas por la 
redistribución y el reconocimiento. Tal como señalé más arriba, los grupos identificados con las luchas por el reconocimiento son los denominados por Fraser (ob. cit.) “colectividades bivalentes", categoría que guió el presente trabajo. La autora explica cómo los grupos que luchan por el reconocimiento son aquellos que lucharon por la redistribución, existiendo una identificación de los grupos de mujeres, pueblos originarios, "raza", entre otros, con la pobreza. Ello me sirvió para identificar la categoría colectividad bivalente con el colectivo "infancias".

Asimismo, desde una mirada jurídica, lecturas referidas al principio del “interés superior del niño" como los trabajos de Beloff (1999), Cillero Bruñol (1999), Fernández Blanco (sin fecha editorial) y Freedman (2005) contribuyeron a un análisis crítico sobre dicho principio.

Por otro lado, y si bien esta tesis no profundiza la problemática de los jóvenes infractores a la ley penal, obras que se abocaron a ello sirvieron de antecedentes a la temática relacionada con el niño abandonado/niño delincuente. Una de ellas fue la obra de Platt (2001) "Los Salvadores del niño" donde vislumbra los modos en que, con la creación de los tribunales de menores en Estados Unidos y el movimiento redentor del niño, se igualó el trato de los "menores delincuentes" y los "menores abandonados". Para conocer como surgen las figuras del "niño abandonado" y el "niño delincuente", a partir de la definición del niño en peligro moral y material las lecturas de Daroqui y Guemureman (1999) y Villalta (2013) son esclarecedoras. Desde un análisis normativo sobre los sistemas de promoción y protección de la infancia rescato la propuesta de Beloff (1999) quien realizó grandes aportes con su análisis respecto a la adecuación de las leyes de la "minoridad" en relación con los estándares fijados por la Convención Internacional de Derechos del Niño/a en los países latinoamericanos.

No puedo dejar de mencionar algunas investigaciones que dan cuenta de la problemática que atraviesan las mujeres encarceladas y sus hijos e hijas en las cárceles de diferentes partes del mundo, como el estudio de la Representación Quáquera ante la ONU de Laurel Townhead (2006) y de Jean Tomkin (2009) y particularmente en las cárceles federales argentinas que evidencia el informe del Centro de Estudio Legales y Sociales junto con el Ministerio Público de la Defensa y la Procuración Penitenciaria de la Nación (2011). 


\section{Aspectos metodológicos}

\section{Ingreso al campo}

Mi primer contacto con personas en situación de encierro fue alrededor del año 2001 en que cursaba las prácticas penales de la carrera de Derecho en la Universidad Nacional de La Plata, donde nos llevaron a hacer una "visita" a la U9 de esta ciudad. Por algún motivo que desconozco no quedaron registros en mi memoria. Aunque sí algo quedó impreso en ella fue la sensación de incomodidad frente a dicha "visita" donde "nosotros", los "normales" los mirábamos a "ellos", los "anormales",

Mis posteriores ingresos a distintas instituciones de encierro me hicieron sentir diferente dado que, se habían planteado objetivos relacionados con la posibilidad de que hubiera un cambio en términos de ejercicio de derechos de las personas privadas de libertad. En el año 2007, tuve la oportunidad de participar como referente regional de la Ciudad Autónoma de Buenos Aires y Provincia de Buenos Aires, de un proyecto llevado a cabo por la Secretaria Nacional de Niñez, Adolescencia y Familia, la UNTREF y UNICEF, y cuyo objetivo era realizar un relevamiento nacional de dispositivos penales juveniles a fin de realizar propuestas para un proceso de cambio. En dicha oportunidad relevé, junto a otros referentes, distintos lugares de encierro para jóvenes en conflicto con la ley penal en la Ciudad Autónoma de Buenos Aires y Provincia de Buenos Aires. La sensación que tuve en ese momento y que me llamó la atención fue la facilidad con que ingresábamos a dichos lugares, lo cual atribuí a que los directores de dichas instituciones, estaban avisados de nuestras visitas y sabían que nos acercábamos desde el Proyecto Nacional de Relevamiento de los dispositivos penales juveniles denominado: "Hacia una mayor adecuación del sistema penal juvenil argentino a la Constitución Nacional y a los estándares internacionales en la materia”. Sin embargo, al concurrir una sola vez a cada lugar de encierro noté que no se llegaba a entablar una relación de confianza entre el entrevistado y el entrevistador. La mayoría eran entrevistas estructuradas y una vez terminadas las mismas nos retirábamos. Luego las entrevistas se entregaban al coordinador junto con un informe que contenía aclaraciones y observaciones para, posteriormente, volcar la información en un informe final del cual los referentes no participamos.

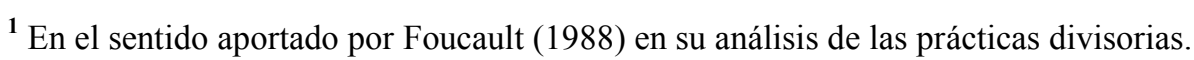


A diferencia de esa experiencia donde la propuesta era ajena y mi rol se reducía a tomar entrevistas, a propósito de esta tesis y haciéndome de los métodos y recursos propuestos por la Antropología Social, definir el problema de investigación, delimitar el referente empírico y analítico, diseñar las técnicas de obtención de datos y la construcción de los mismos para su posterior análisis y conclusión estuvieron a mi cargo. Sin perder de vista mi formación de abogada he decidido para esta investigación enfatizar en el trabajo de campo etnográfico en tanto marco reflexivo para la interpretación. En ese sentido, deseo aclarar que la finalidad de esta tesis no apunta a una generalización de los resultados, sino, acercar conocimiento sobre realidades y/o experiencias particulares presentes en los sentidos otorgados por los/as propios/as protagonistas.

La primera aproximación a la Unidad 33 fue a partir de mi incorporación al proyecto de extensión de la Facultad de Ciencias Jurídicas y Sociales de La Plata denominado "Unidad de atención en conflictos juveniles" (UACJ). Uno de los objetivos de dicho proyecto fue poner en marcha un programa enmarcado en la propuesta de la justicia restaurativa siendo el pabellón 10 , donde las detenidas se alojaban junto a sus hijos/as, el elegido. Cabe aclarar, que si bien, el objetivo de máxima de dicho proyecto era continuar con dicha propuesta en otros pabellones, el mismo no pudo concretarse.

Ya hacía algunos años daba vueltas en mi cabeza el "problema social" de niños y niñas en contexto de encierro junto a sus madres. Algo no encajaba, algo no cerraba pero no alcanzaba a problematizar ese aspecto de la realidad carcelaria.

Es interesante tener presentes los objetivos del programa restaurativo. Los mismos fueron planteados teniendo en cuenta, tanto las circunstancias por las que cada una de las mujeres se encontraba privada de su libertad, como por los modos de reponer los derechos vulnerados que, en términos de las mujeres "madres" detenidas, se subsumía a la experiencia de compartir el contexto de encierro con sus hijos/as, fundamentalmente, al ejercicio de la maternidad en el encierro y a la posibilidad de construir redes sociales con el afuera que ayudaran a la reinserción de las mujeres que estaban en condiciones procesales de obtener su libertad. Lograr lo que se pautaba para cada encuentro resultó muy dificultoso ya que en cada uno de ellos, que se concretaba cada quince días, las mujeres habían pasado por diferentes situaciones que modificaban la agenda de trabajo. 
El ingreso a la Unidad fue difícil, aun yendo con la directora del proyecto nos hacían esperar en la puerta hasta que nos dejaban pasar, luego de averiguar desde donde veníamos y a qué íbamos. Después de haber ido muchos viernes con continuidad, esto es, de ser (re)conocidos, el día en que fuimos sin la directora nos hicieron esperar en la puerta más de media hora porque debían averiguar "algo" y no nos dejaron ingresar. Con el devenir de los encuentros y la agenda que se pautaba día a día según las urgencias de las mujeres llegó el fin del año 2013 y el trabajo realizado en el pabellón 10 se dio por concluido.

Esa experiencia de casi dos años me llevó por un lado, a retomar la asignatura pendiente que era realizar mi tesis de maestría y por el otro, a definir el tema de investigación a partir de la construcción del problema analítico.

\section{Metodología empleada}

La presente investigación se enmarca en el método cualitativo. Específicamente en el trabajo de campo etnográfico, en su triple acepción de enfoque, método y texto (Guber, 2001).

Como enfoque este trabajo busca comprender a través de los informantes "privilegiados", las formas de concebir el interés superior del niño/a, de dar sentido a las prácticas de crianza, de indagar los sentidos dados a la maternidad y a la niñez en un espacio de encierro. Es decir, indaga en la descripción de "como" es para ellos (los agentes, actores, sujetos sociales). Siguiendo a Guber,

"como enfoque la etnografia es una concepción y practica de conocimiento que busca comprender los fenómenos sociales desde la perspectiva de sus miembros (entendidos como "actores", “agentes" o "sujetos sociales")” (Guber, 2001:12,13).

Desde la segunda acepción, como método, fue lo que me llevó a elegir como herramienta de construcción de datos a la observación participante sin perjuicio de utilizar también otras técnicas como las entrevistas semiestructuradas, documentos escritos por las madres, legajos internos, notas de campo y documentación jurídica diversa. En este sentido, son los actores y no el investigador los privilegiados para expresar en palabras y en prácticas los sentidos de sus actos cotidianos, de su vida, de 
sus comportamientos, de sus relaciones sociales. Esta situación corre al investigador del centro de la escena. Este proceso, conforme la autora, tiene dos aspectos. Por un lado, "el investigador parte de una ignorancia metodológica y se aproxima a la realidad que estudia para conocerla" y por otro lado "el investigador se propone interpretar/describir una cultura para hacerla inteligible ante quienes no pertenecen a ella” (Guber, 2001:16,17).

Mirar la cárcel, el pabellón, la celda, las relaciones como objeto de investigación previamente construido, contar las rejas que se atraviesan hasta llegar al pabellón, establecer que espacio físico hay en las celdas, observar con que juegan los niños/as, observar las relaciones dadas entre ellos, con sus madres, con el personal penitenciario, dio cuenta del arduo camino recorrido del des-conocimiento al reconocimiento (Guber, 2001:16).

Asimismo, durante el trabajo de campo, es donde doy cuenta de la reflexividad inherente al mismo. Fue en este proceso en el que transcurrió mi embarazo $\mathrm{y}$ en donde diversas sensaciones difíciles de describir me invadieron. En los momentos en que ingresaba a la cárcel, en momentos en que me hacía ecografías, se evidenciaba "el proceso de interacción, diferenciación y reciprocidad entre la reflexividad del sujeto cognoscente - sentido común, teoría, modelos explicativos - y la de los actores o sujetos/objetos de investigación” (Guber, 2001:53). Durante este proceso de interacción, diferenciación y reciprocidad es donde "el conocimiento se revela no "al" investigador sino "en" el investigador, debiendo comparecer en el campo, debiendo reaprenderse y reaprender el mundo desde otra perspectiva” (Guber, 2001:54)

La presente investigación, como texto, es el resultado del trabajo que aquí describo. La relación entre teoría y práctica a través de la descripción "densa" en el sentido dado por Geertz (1973), a fin de acercar la temática de estudio a los lectores no familiarizados con la misma.

\section{Plan de trabajo}

Para argumentar los temas centrales de este trabajo presento el producto de mi investigación en tres capítulos. 
En el capítulo 1 me propongo presentar, describir y analizar la Unidad 33, su estructura tanto funcional como orgánica, sus relaciones con otras instituciones que si bien no dependen de ella, están ligadas de algún u otro modo. También me propongo describir los sentidos dados por los actores en escena a dicha Unidad y a la finalidad del encierro.

En el capítulo 2 desarrollo y describo los discursos y prácticas presentes tanto en el viejo paradigma del Patronato de Menores como en la actual doctrina de la Protección Integral de los niños y niñas. Luego de un recorrido por las distintas nociones de infancia me detengo a analizar dichos discursos y prácticas utilizando la categoría de colectividades bivalentes acuñada por Fraser (1997), la cual me guió para analizar las infancias que viven el encierro.

Finalmente en el capítulo 3 desarrollo los significados dados por los distintos actores de la Unidad 33 al interés superior del niño, como principio de derechos humanos de dicho colectivo. También identifico los modos en que los mismos actores significan el rol materno y el ejercicio de la maternidad en el contexto de encierro, así como, los diferentes modos de dar sentido a la construcción de subjetividades en base a las representaciones sobre la crianza de los niños y niñas en dicho contexto.

Este trabajo habla de infancias, de maternidad, de crianza, pero fundamentalmente habla de historias recientes que lejos de pretender universalizarlas nos conminan a reflexionar sobre los derechos y su ejercicio. 


\section{CAPÍTULO 1}

\section{LA UNIDAD PENITENCIARIA Nº 33 DE LA PLATA}

\subsection{Presentación de la Unidad 33}

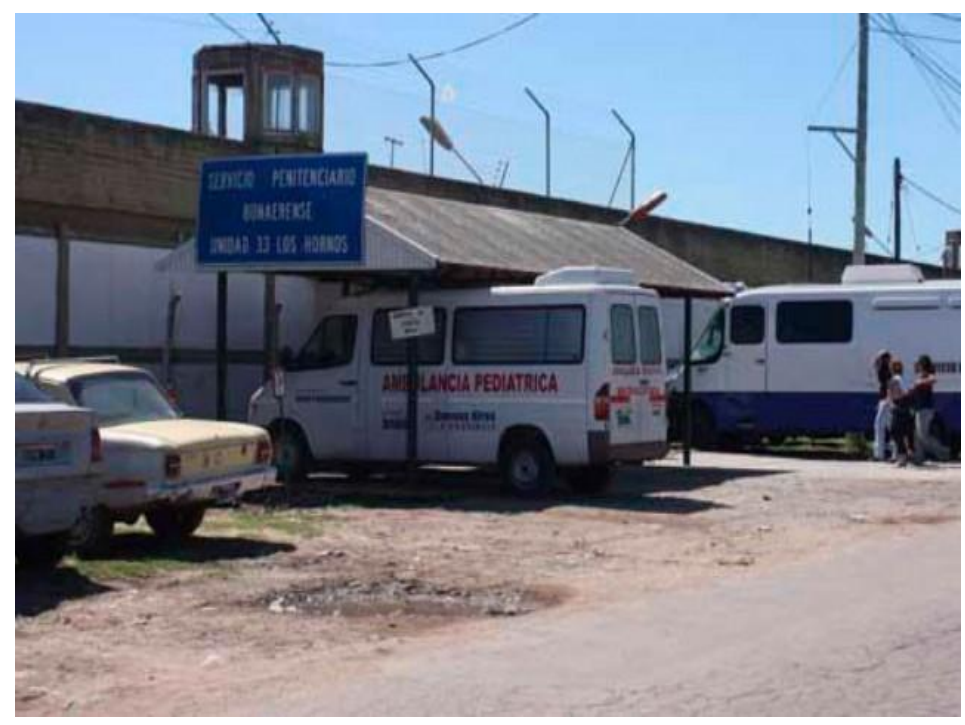

La Unidad Penitenciaria 33 es parte de las cincuenta y un (51) Unidades Penitenciarias que posee el Servicio Penitenciario de la Provincia de Buenos Aires. La misma, se encuentra destinada a alojar mujeres procesadas y condenadas, y es la única de la provincia que cuenta con pabellones en los que se alojan a mujeres con sus hijos/as.

La Unidad 33 se encuentra situada en el barrio de Los Hornos de la ciudad de La Plata, en las calles 149 y 71 y fue inaugurada en el año 1999 durante el gobierno provincial ejercido por Eduardo Duhalde.

Como toda unidad carcelaria, la Unidad 33 está diseñada en clave de seguridad, con un muro perimetral alto y garitas de seguridad con una distancia de alrededor de 100 metros unas de otras. La misma está conformada por tres módulos clasificados como A, B y C. Cada módulo cuenta con 4 pabellones destinado un pabellón a la escuela, cursos y talleres. En el módulo C se encuentran alojadas las detenidas que son madres junto a sus niños/as pequeños o nacidos en el encierro. 


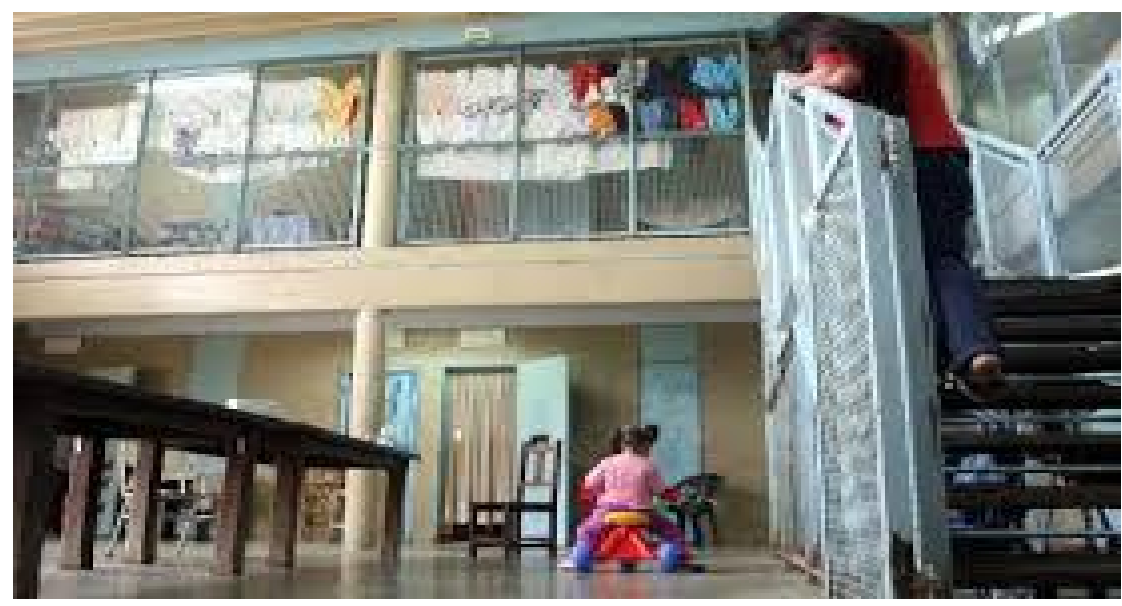

Los pabellones que integran el módulo C son los llamados "de madres" y se diferencian de los pabellones llamados “de población”. Entre los mismos no existen diferencias ni edilicias ni prácticamente funcionales. Sin embargo, no es un dato menor el horario de cierre de las celdas; mientras en los pabellones "de población" se cierran las celdas a las 18:00 hs., las celdas de los pabellones "de madres" permanecen siempre abiertas. El pabellón 10 al que tuve acceso tiene 14 celdas, 7 abajo y 7 en una planta alta que balconea sobre un espacio común a todas las celdas. Ese espacio tiene una mesa, algunas sillas, heladera, cocina, duchas y baños. A su vez, cada pabellón tiene un patio en el que cuelgan su ropa y tienen algún juego de plaza para los niños/as.

La característica de esta Unidad respecto de otras Unidades penitenciarias es que en la misma se alojan mujeres embarazadas y madres con sus hijos/as, los/as cuales pueden estar allí hasta los cuatro años. ${ }^{2}$ En función de ello, ésta es la única que posee un equipo de profesionales llamado Consejo Asistido. Volveré sobre éste más adelante.

\subsection{Actores en escena. La organización funcional}

La Unidad 33 está organizada jerárquicamente siendo su máxima autoridad un director o directora. Entre las tareas que debe llevar a cabo el director/a se encuentran las de programar y supervisar las áreas Asistencia y Tratamiento, Seguridad y Administrativa; implementar los Programas de Asistencia y Tratamiento para procesados/as y condenados/as en las áreas Convivencia, Educación, Trabajo, Tiempo

\footnotetext{
${ }^{2}$ La ley de ejecución penal de la Provincia de Buenos Aires no establece un límite de edad para que los niños/as permanezcan junto a sus madres pero en la práctica se aplica la ley nacional de ejecución penal 24.660 (y sus modificatorias) que en su artículo 195 establece que las mujeres madres podrán "retener" consigo a sus hijos menores de cuatro años, organizándose cuando se encuentre justificado un jardín maternal a cargo de personal calificado.
} 
Libre y Asistencia Psico-social; garantizar los derechos de los procesados/as y condenados/as a la atención y tratamiento integral para la salud; alojamiento en ámbitos que satisfagan condiciones de salubridad; vestimenta apropiada; alimentación de valor nutritivo calórico suficiente; comunicación con el exterior a través de visitas, correspondencia, comunicaciones telefónicas; ejercicio libre de culto religioso y asesoramiento legal.

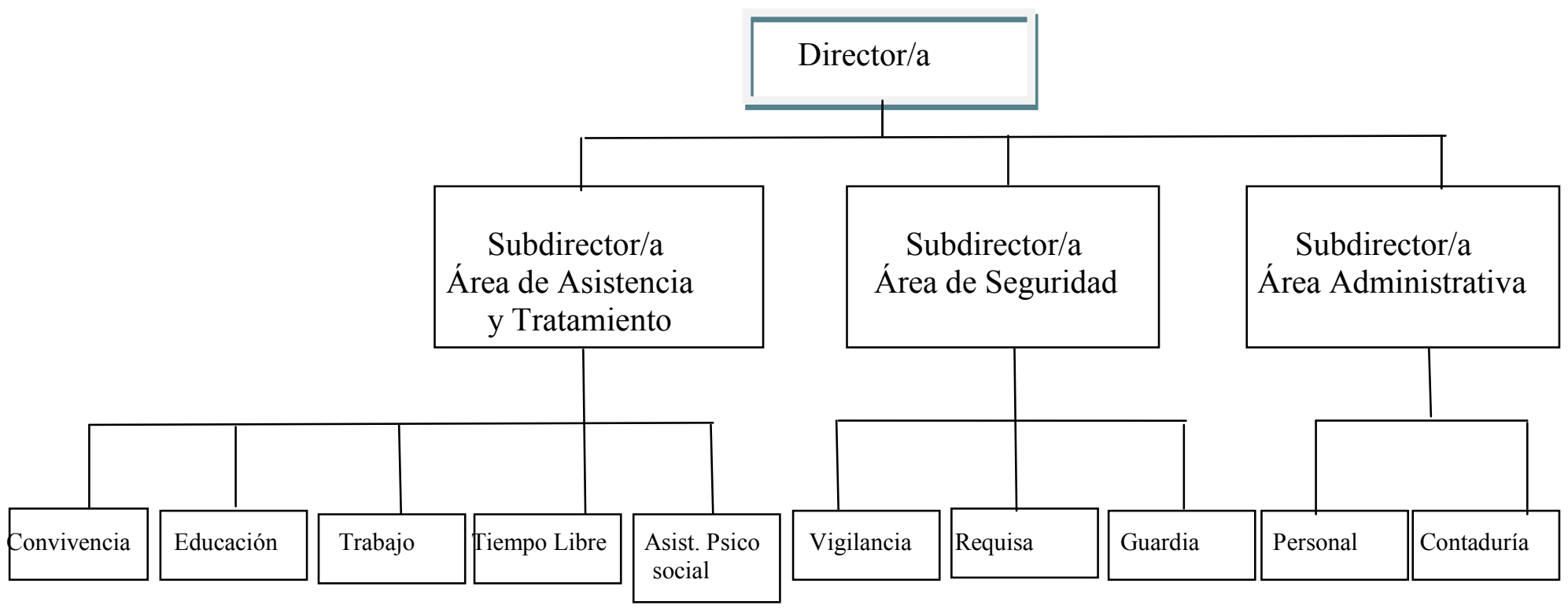

Durante el período 2012-2013 me incorporo a un proyecto de extensión universitaria de la Facultad de Ciencias jurídicas y sociales de la UNLP, denominado "Unidad de atención en conflictos juveniles", el cual estaba en marcha. Es un dato a tener en cuenta que al poco tiempo de mi participación en dicho proyecto, se produce un cambio en la dirección de la unidad. Esa situación llevó a que el equipo volviera a hacer las gestiones necesarias para hacer la presentación pertinente ante la nueva autoridad para así, ponerla al tanto de nuestra actividad académica a partir de hacer explícita nuestra propuesta. Sin embargo, su función fue bastante acotada en el tiempo. Al tiempo de concluido el proyecto de extensión y habiendo definido el tema de la presente investigación, cuando busco volver a restablecer el contacto con el director, se me informa que el mismo había cesado en su función, quedando a cargo de la Unidad una directora. Dada mi experiencia en el campo, puedo sostener que los cambios producidos en la organización jerárquica institucional generaron un retraso en el gerenciamiento de la misma. Es sabido que toda nueva gestión precisa, necesariamente, de un tiempo para el diseño e implementación de programas, para la evaluación de las necesidades o problemas específicos detectados y para conocer al personal con el que se cuenta para 
llevar a cabo lo proyectado, por lo tanto, los cambios de autoridad no abonaron, en lo inmediato, a la construcción de puentes o redes sostenidas en el tiempo entre el personal penitenciario y las detenidas.

Volviendo a la organización institucional, las áreas de Seguridad, Asistencia y Tratamiento, y Administrativa tienen cada una un subdirector/a a su cargo. La subdirección de Seguridad tiene entre otras funciones la de coordinar y supervisar las secciones a su cargo denominadas "Vigilancia", "Requisa" y "Guardia de Seguridad exterior", y mantener el orden y la disciplina entre las internas y las relaciones entre éstas y el personal. La subdirección de Asistencia y Tratamiento tiene entre otras funciones la de coordinar y supervisar las tareas de las secciones a su cargo denominadas "Registro de internos", "Educación", "Trabajo", “Asistencia Social", "Técnico criminológica", "Legal”, "Comunicación con el exterior", "Conductas adictivas" y "Cultos". La Subdirección Administrativa tiene a su cargo la tarea de coordinar y supervisar las secciones denominadas "Personal” y "Contaduría".

De todas esas áreas me contacté, en un principio, con la jefa de asistencia y tratamiento quien cumplía funciones desde hacía siete años habiéndose desempeñado anteriormente, primero en el cargo de jefa de pabellón y luego como jefa de módulo. De esto inferí que el conocido dicho: "pagar derecho de piso", en la unidad, se "paga" estando cerca de las detenidas. A medida que los operadores/as van ascendiendo se van alejando no sólo del último escalafón, sino también, del contacto cotidiano con las mujeres detenidas. Esto se corresponde con la cantidad de rejas que deben atravesarse para salir de la Unidad. A menor escalafón, mayor cercanía con las detenidas, por lo tanto, mayor es la cantidad de rejas a ser atravesadas en relación con la salida. A medida que se producen los ascensos en el escalafón, la cantidad de rejas a trasponer se va reduciendo. Es decir, la relación rejas/salida es directamente proporcional a la organización jerárquica institucional: guardias del pabellón, jefes/as del pabellón, jefes/as de modulo, jefes/as o subdirectores/as de áreas y directores/as.

El régimen de asistencia y tratamiento, que se corresponde con la Subdirección "Área de Asistencia y Tratamiento", se encuentra regulado en la ley 12.256. Dicha ley en su art. 4 determina que su fin es la adecuada reinserción social de los procesados y condenados a través de la asistencia o tratamiento y control, y en su art. 5 estipula que la asistencia y/o tratamiento están dirigidos al fortalecimiento de la 
dignidad humana y el estímulo de actitudes solidarias inherentes a su condición de ser social.

\subsection{El "Consejo Asistido". Censor de la maternidad y la crianza}

El Consejo Asistido (CA de aquí en más) es un organismo integrado por diferentes profesionales creado por la ley de ejecución penal bonaerense $n^{\circ} 12.256$ que tiene como finalidad privilegiar la relación madre e hijo/a, siempre que se encuentren alojados/as en establecimientos penitenciarios. La ley en su art. 18 dispone:

"A fin de privilegiar la relación materno infantil en los lugares donde se alojen madres que convivan con hijos y en los casos en que el Servicio Penitenciario Bonaerense cuente con dichos establecimientos, se formará un Consejo asistido integrado por profesionales médicos pediatras, psicólogos, trabajadores sociales y docentes, quienes se ocuparán de estructurar una didáctica acorde con los principios pedagógicos científicos que permitan aplicar métodos activos, para integrar al niño a Jardines Maternales. Se brindará un ambiente físico que satisfaga los intereses y necesidades infantiles. Los niños podrán asistir a Jardines Maternales de la comunidad."

Durante el tiempo que llevó mi trabajo de campo, el CA estuvo integrado por una obstétrica que realizaba tareas administrativas, dos psicopedagogas, una psiquiatra infantil, una psicóloga, una docente y una trabajadora social. Durante ese tiempo me invadía cierto temor de no poder concretar las entrevistas necesarias para la investigación. Dicho temor se fundamentaba en pequeños hechos vividos durante mis primeras idas a la Unidad, como por ejemplo, la espera en la puerta, las reiteradas explicaciones que debía dar, tanto por teléfono como personalmente, a todos los que me atendían sucesivamente hasta llegar a la persona a la que finalmente había solicitado entrevistar y a quien debía volver a explicar las razones de mi llamado o presencia. Ante estas circunstancias signifiqué estratégico entrevistar en primer término a la directora. En una institución jerárquicamente organizada mencionar, no sólo, que tenía la anuencia de la máxima autoridad, sino también, que dicha autoridad había sido mi primera entrevistada conformaría la "carta de presentación" suficiente para llevar a cabo mi propósito con el resto de los operadores. 
Así fue que después de varios llamados telefónicos y de una cita suspendida "por razones de trabajo" logré concretar la entrevista con la directora, quien me proveyó del corpus de sentidos necesario para la construcción de datos que más adelante retomaré, a la vez, que ofició de "trampolín" ineludible para acceder a otros actores institucionales. A modo de ejemplo, al finalizar nuestro encuentro que transcurría en su despacho, alrededor de las 15:00 hs., le solicité autorización para entrevistar a algún/a integrante del CA, ante lo cual me respondió asombrada con otra pregunta: “¿Ahora?”. Mi respuesta fue inmediata: "Ahora o cuando la integrante del Consejo me pueda recibir" Luego de ir a consultar a alguien que estaba en otra oficina, me indicó que concurriera a la Unidad en un día y horario determinados, al que concurrí puntualmente.

Y llegó el día y la hora acordada con la directora para entrevistar a algún miembro del CA. Luego de esperar en la puerta de la Unidad un buen rato y de explicar varias veces quien era y a que iba, me abrieron la primer reja de las cuatro que luego tuve que atravesar hasta llegar al lugar donde funciona este espacio singular denominado Consejo Asistido. En la puerta de entrada a la cárcel me recibió la persona que sería mi entrevistada: una empleada administrativa que tenía título de obstétrica. Me preguntó quien era y las razones por las que me encontraba allí. Finalmente llegamos a su oficina luego de atravesar varias rejas, las cuales no se abrían hasta tanto se cerraran las anteriores. La oficina es muy pequeña, falta de pintura en sus paredes y apenas provista de un escritorio, dos sillas, algunos estantes y unas cajas de cartón que ofician de archivos y de donde asoman papeles de colores.

Después de presentarme y de iniciar la entrevista con la pregunta: “¿cuál es su tarea en el CA?", me respondió que su tarea era la de "realizar todo tipo de trámite que tenga que ver con los niños y niñas que conviven con sus madres". Luego le pregunté por la tarea específica del CA como organismo y refirió a que dicho espacio abordaba "todas y cada una de las necesidades de las madres y embarazadas alojadas acá en la Unidad 33, desde la "asignación universal" hasta que los chicos concurran a los establecimientos educativos, a que tengan un vínculo con la familia en el afuera, trabajar la externación con la madre”.

En un momento, durante la entrevista, alguien golpeó la puerta y esperó. Enseguida dejé de grabar para que la entrevistada pudiera atender. Cuando la entrevistada dijo "pase", abrió la puerta una mujer, y dado que escuché el diálogo entre 
ambas comprendí que era una mujer detenida que, en voz muy baja, pedía permiso para llevar consigo una cartulina de color. Como mi entrevistada asentía señalando que se podía llevar lo que quisiera, la mujer tomó la cartulina y se fue. La entrevistada me miró y con tono risueño me dijo: “¿ves? ellas entran y salen, ahora creo que están organizando los cumpleaños del mes, entonces se llevan estos papeles de colores para decorar el pabellón."

Ese “¿ves? ellas entran y salen” fue su respuesta a una de mis preguntas de conocimiento respecto a cuál es el modo en que el CA se contacta con las mujeres presas para iniciar su trabajo con las mismas. Esta respuesta me llevó a preguntarme ¿Qué sentidos tiene para la entrevistada esa relación madre/hijo que debería trabajar el CA? Comprendí que para la entrevistada los sentidos dados a la relación madre/hijo-a no tienen que ver con los trámites de "asignación universal" o con el trabajo de la externación del niño/a y su separación con la madre, sino que van dirigidos a los modos de ejercer la maternidad y la crianza que en el ideario común y en el de la entrevistada se relaciona con los quehaceres del hogar y la producción de manualidades para los cumpleaños de los hijos e hijas. De este modo la relación madre/hijo-a se reduce a las formas en que se ejerce la maternidad y la crianza y la tarea del CA reducida a ser un censor de maternidad y crianza.

\subsection{Mujeres detenidas en la Unidad 33 y su relación con los actores involucrados en el proceso judicial}

El sistema penal argentino es una forma de control social institucionalizado que se manifiesta a través de la estructura policial, judicial y ejecutiva. Cuando una persona con su accionar comete un hecho tipificado en la ley penal como delito es posible que se inicie un proceso judicial en su contra. Durante todo ese proceso penal aparecen en escena diferentes actores como la policía, jueces, fiscales, defensores y penitenciarios, entre otros, con los que los/as detenidos/as indefectiblemente, en algún momento, tomarán contacto con mayor o menor frecuencia. Los imputados/as deberían atravesar el proceso penal en libertad hasta que una condena determine su responsabilidad en relación con el hecho que dio inicio al proceso. Excepcionalmente el juez puede dictar una medida restringiendo la libertad del imputado/a conforme el art. 144 del Código Procesal Penal de la Provincia de Buenos Aires que establece: 
"El imputado permanecerá en libertad durante la sustanciación del proceso penal, siempre que no se den los supuestos previstos en la Ley para decidir lo contrario. La libertad personal y los demás derechos y garantías reconocidos a toda persona por la Constitución de la Provincia sólo podrán ser restringidos cuando fuere absolutamente indispensable para asegurar la averiguación de la verdad, el desarrollo del procedimiento y la aplicación de la ley.”

Sin embargo, en la Unidad 33 más de la mitad de las mujeres alojadas no se encuentran con sentencia condenatoria firme. De 285 mujeres que se encontraban alojadas en el año 2012 en la Unidad 33, sólo 196 estaban en calidad de procesadas siendo 89 las condenadas. ${ }^{3}$

En nuestro caso, el contacto que tienen con los actores de la justicia es muy esporádico. De las entrevistas realizadas tanto a las mujeres como a los empleados/as y funcionarios/as surge que los defensores y jueces pocas veces asisten a la Unidad y que, en las mujeres detenidas, existe un desconocimiento bastante generalizado sobre sus defensores y el estado de sus causas.

Una de las mujeres entrevistadas, al preguntarle si tenía defensor oficial o particular y si éste iba a la cárcel, manifestó tener defensa oficial y enfáticamente a la pregunta respecto a si lo veía dijo: “;No! Arreglátelas como puedas. El día del juicio, si es posible, o te hunden o llegan a un arreglo, es así."

Para acortar la distancia que existe con la estructura judicial, la Unidad 33 posee un espacio denominado "Oficina Judicial" que depende del Departamento de Derechos Humanos de la Procuración de la Corte de la Provincia de Buenos Aires. La función de la Oficina Judicial, como me contaba la jefa de despacho, única empleada que representa a dicha oficina en la Unidad, es acercar a las detenidas a los procesos judiciales a través de velar por condiciones dignas de trato y detención, es decir, atender todas las cuestiones que hacen a la vida cotidiana de las personas privadas de la libertad y de gestionar pedidos de comparendo. Los pedidos de "comparendo" incluyen presentarse en audiencia ante el juez. Para ello, las detenidas o detenidos son trasladados en un camión penitenciario, en el que suben a primera hora a todos los

\footnotetext{
3 Dato aportado por el Servicio penitenciario de la Provincia de Buenos Aires al Observatorio de Violencia de Género.
} 
internos e internas que ese día se presentan en tribunales en diferentes horarios y direcciones, volviendo a última hora.

La creación de una Oficina judicial con sede en la Unidad es muy interesante ya que la sola presencia judicial debería ser un contrapeso. Es una suerte de “ojo judicial” puesto al interior de la unidad penitenciaria dada su autoridad para informar a los/s jueces/juezas y para sancionar conductas y prácticas definidas inapropiadas. A su vez, constituye el espacio de inmediatez al que pueden recurrir las detenidas para consultar sobre sus causas y plantear los problemas que atraviesan dentro de la Unidad.

\subsection{Otras Instituciones vinculadas con la Unidad}

\subsubsection{El Centro de Orientación y Asistencia para Familiares de Detenidos (COFam)}

El Centro de Orientación y Asistencia para Familiares de Detenidos (COFam) es una organización creada en el marco de un proyecto de extensión de la Facultad de Trabajo Social de la UNLP que tiene como objetivo, como su nombre lo indica, orientar y/o asistir a familiares de detenidos/as en general, recibiendo consultas de las familias de los mismos/as. Al entrevistar a la directora del COFam me relató que en junio de 2012 se presentó la posibilidad de realizar un "Programa restaurativo de construcción de la niñez" en el marco de la secretaría de extensión nombrada, desde una perspectiva de restablecer derechos dentro de la Unidad 33. Es partir de allí que comienzan a trabajar dentro de la misma.

\subsubsection{El Jardín Maternal}

El Servicio penitenciario posee tres jardines maternales en la ciudad de La Plata denominados "Los Peques", "Campanitas" y "Las Palomitas"4 "Los Peques" y "Campanitas" son jardines creados sólo para los hijos e hijas de los/as empelados/as del Servicio Penitenciario. El jardín maternal "Las Palomitas”, en cambio, se creó para que

\footnotetext{
${ }^{4}$ Los tres jardines, según las palabras de la directora de "Las Palomitas", pertenecen al Servicio Penitenciario por lo cual dependen del mismo y no del Ministerio de Educación. Conforme lo relatado por la directora habrían realizado un pedido para ser supervisados por dicho Ministerio pero al momento no habían obtenido respuesta.
} 
las mujeres detenidas que se encuentran viviendo junto a sus hijos e hijas tuvieran la posibilidad de un jardín donde enviarlos, por ello en este acápite me centraré en la descripción del mismo.

Las maestras del jardín "Las Palomitas" poseen títulos habilitantes oficiales respecto de su rol-profesión pero son empleadas del Servicio Penitenciario de la Provincia de Buenos Aires. El establecimiento no se encuentra abierto a la comunidad en general, sino, constituye un dispositivo dirigido a los hijos/as del personal del Servicio penitenciario y a los/as hijos/as de las mujeres detenidas en la Unidad 33. El mismo dispone de cincuenta vacantes para los hijos e hijas del personal penitenciario y de cincuenta vacantes para los hijos e hijas de las mujeres detenidas. En el caso de las detenidas, la inscripción al mismo se realiza por pedido de la madre y se formaliza a través del Consejo Asistido. Las notificaciones e informes entre las docentes y las detenidas se concreta a través de un cuaderno de comunicaciones lo cual no obsta que se realicen reuniones en la Unidad 33, en general, al inicio y al final del ciclo escolar.

\subsection{Miradas, tramas y tensiones. Los sentidos otorgados a la Unidad 33 desde la perspectiva de sus actores}

Luego de la presentación estructural-formal de la Unidad 33, me interesa describir las prácticas y representaciones que los distintos actores institucionales producen y reproducen al interior de dicha unidad otorgándole sentido.

Por ejemplo, para la jefa de asistencia y tratamiento, refiriéndose exclusivamente a la oferta de los diferentes "oficios" que brindan en la Unidad 33 dijo "es una unidad atípica [...], es una unidad muy tratamental". También agregó: "la interna cuando está en ocio es donde se desvirtúa y donde aparecen los problemas, los conflictos dentro de la población carcelaria; y al estar ocupadas, no solamente no hay conflicto sino que le sirve para su vida cuando salgan. ,5

Esta mirada de la Unidad 33 coincide con la idea del trabajo en el penal ya analizada por Foucault (1989) en el sentido de que como principio de orden genera acciones regulares en los cuerpos y suprime formas de distracción. El trabajo de la

\footnotetext{
5 Respecto al significado dado a "tratamental" me referiré más adelante.
} 
prisión debe ser pensado como un sistema, "como si fuera una maquinaria en sí que transforma al penado violento, agitado, irreflexivo, en una pieza que desempeña su papel con una regularidad perfecta” (Foucault, 1989: 245).

Foucault transcribe una cita de Bérenger de 1836 que va en la misma línea argumental que la de la jefa de asistencia y tratamiento que dice:

"Al tener ocupado al recluso, se le dan hábitos de orden y de obediencia; se le hace diligente y activo, de perezoso que era... con el tiempo, encuentra en el movimiento regular de la casa, en los trabajos manuales a los que se le ha sometido... un remedio seguro contra los desvios de su imaginación". (Bérenger en Foucault 1989:245)

Así es como esta cita de 1836 es relevante para iluminar la mirada actual respecto al trabajo, "oficios", presente en el discurso de la jefa de asistencia y tratamiento. Asimismo, la directora, al referirse a la Unidad agrega "[somos] la unidad mimada del servicio, es muy raro que nos falte algo", haciendo referencia exclusiva a los bienes materiales y naturalizando el hecho de que en las cárceles dichos bienes escasean. De esto también dan cuenta las entrevistas realizadas a las detenidas, aunque ponen las palabras de la directora en interdicción. Según me mencionaron, la comida, por ejemplo, es insuficiente y de muy mala calidad. Muchas de ellas contaron que la carne y las papas casi no se pueden comer, que la leche es insuficiente y que otros lácteos, como yogures, carecen de existencia. De distintas frases como: "mi hijo supo lo que era un yogur porque me lo trajeron de la visita" o "ahí con una cebolla haces magia, con un churrasco haces magia.", se desprende que las miradas sobre los bienes materiales, en este caso los alimentos, son contrapuestas. Mientras la directora sostiene que la falta es una excepción, las detenidas señalan la escasez como la regla.

La tensión que subyace en estos discursos evidencia las violencias estructurales en los lugares de encierro, condiciones de detención indignas y situaciones de subestimación, desidia y humillación. Por ejemplo que a un niño/a le pueda entrar una cucaracha en el oído, tal como lo comentara su madre, que no haya medicación para las patologías que aparecen con mayor asiduidad, que cuando algunas detenidas necesitan tratamiento odontológico el profesional decida quitar piezas dentales antes que repararlas por carencia del material específico para realizar dicha reparación, que 
otras pierdan sus turnos para intervenciones quirúrgicas por la imposibilidad de realizar en tiempo y forma los estudios pre-quirúrgicos, son algunas de las situaciones que reflejan algunas de las modalidades en que se expresa la violencia institucional. ${ }^{6}$

Más allá de los sentidos otorgados por la directora y la jefa de asistencia y tratamiento a la institución, la misma no escapa a las características de las instituciones totales, entendidas estas como "un lugar de residencia y trabajo, donde un gran número de individuos en igual situación, aislados de la sociedad por un periodo apreciable de tiempo, comparten en su encierro una rutina diaria, administrada formalmente." (Goffman, 1992:13).

Todos los aspectos de la vida (dormir, trabajar, jugar, comer) se desarrollan en el mismo lugar y bajo la autoridad formal de la directora. Sin embargo, no debemos soslayar que su autoridad definida en acciones a seguir está atravesada por la de una suerte de operadores penitenciarios tales como guardias, jefes de áreas, personal médico. A su vez, estos aspectos de la vida cotidiana se producen y reproducen en compañía de un gran número de "otros" (las mismas detenidas), a quienes, en términos generales, se las despersonaliza a través del trato y de la estricta y rutinaria programación de las actividades.

Sin embargo, además de la autoridad ejercida diferencialmente por los distintos operadores penitenciarios he podido observar otros atravesamientos intersticiales de peso relativo, aunque no por eso menos relevantes. Es el caso de la autoridad de las líderes de pabellón donde también se construyen relaciones de poder. Estas mujeres son las que organizan el "orden" dentro de cada pabellón y a quienes responden las detenidas que comparten su espacio. Las líderes son las que negocian con el personal penitenciario, autorizan determinadas acciones a llevar a cabo por sus coresidentes a través de la construcción de alianzas instrumentales y las que distribuyen

\footnotetext{
6 No profundizaré este campo específico ya que el objeto de mi tesis se centra en los sentidos o representaciones sobre infancias en contexto carcelario y no en la "violencia institucional", más allá de que las discusiones al respecto estuvieron presentes en la construcción de mi problema de investigación, entendida la "violencia institucional" como hechos y/o situaciones que involucran violaciones a los derechos humanos por parte de funcionarios/as pertenecientes a las fuerzas de seguridad, fuerzas armadas, personal penitenciario y efectores de salud en contextos de restricción de libertad y/o autonomía.
} 
bienes materiales y simbólicos. Ejemplo de ello es su poder de decisión sobre el posible ingreso o no de una nueva detenida al pabellón que se lidera.

De lo antedicho se desprende, que a pesar de ser una institución cerrada donde la jerarquía verticalizante es su impronta constitutiva, el ejercicio de la autoridad al igual que el ejercicio del poder no es lineal. Atendiendo a las detenidas he podido observar que las relaciones de poder que establecen se expresan de modos diversos. Mientras, frente a determinadas circunstancias, algunas se manifiestan de manera sumisa, otras asumen modos activos de intervenir aunque les cueste una sanción. Por lo tanto, aunque estemos frente a una institución total, existe lo que Foucault denomina resistencia.

En términos foucaultianos no hay poder sin resistencia, sin estrategia de lucha, un modo de acción eventual en las relaciones de poder. Según el autor:

"en el corazón de las relaciones de poder y como condición permanente de su existencia, hay una "insumisión" y libertades esencialmente obstinadas, no hay una relación de poder sin resistencia, sin escapatoria o huida, sin un eventual regreso. Toda relación de poder implica, pues, por lo menos virtualmente, una estrategia de lucha." (Foucault, 1988:19)

Sostengo junto al autor que más que hablar "del poder" debemos hablar en términos de relaciones de poder sin perder de vista que en toda relación de poder debe haber una cierta forma de libertad ${ }^{7}$. El poder sólo puede ser ejercido en la medida en que "el sometido" tenga alguna capacidad de resistencia. A modo de ejemplo traigo un episodio ocurrido en la unidad a principios de 2013, se trata de un incendio producido en el pabellón 10 o “de madres”. Según el relato de las detenidas el incendio se suscitó en una celda por el mal funcionamiento de una estufa. Esa situación generó una sensación de nerviosismo, inestabilidad, temor/terror, indefensión, "odio" que llevó a todas las mujeres alojadas en el pabellón a querer salir de ese pabellón junto a sus hijo/as de modo inmediato. Ante la demora en la apertura de la reja, una de las detenidas le pega una cachetada a la celadora lo que le valió una sanción.

\footnotetext{
${ }^{7}$ Cabe recordar que para el autor el poder se ejerce sobre sujetos libres, es decir, sujetos que disponen de un campo de varias conductas posibles. Esto es, refiere a sujetos individuales o colectivos que tienen ante ellos un campo de posibilidades en el que pueden darse muchas conductas, muchas reacciones y diferentes modos de comportamiento.
} 
Sin embargo, la resistencia no es la única vía para la construcción de subjetividad. Dicho de otro modo, la resistencia es entre otras, una forma de agencia. En general, la capacidad de agencia vislumbrada es la que toma la forma de resistencia, de subversión o de resignificación, entendidas en oposición a la represión, la dominación y la subordinación (Mora: 2010). En ese sentido, Sherry Ortner (2009), señala que la exploración de las relaciones entre agencia y poder la ha llevado a reconocer que la agencia va más allá de la oposición a los mecanismos de dominación. Entendiendo que la agencia es una propiedad universal de los sujetos sociales, es igualmente distribuida y culturalmente construida, distingue analíticamente dos formas de agencia que, en la práctica son inseparables. La primera, es la agencia como intención y la segunda es la agencia como resistencia al poder. Mientras que esta última es un modo oposicional de agencia, un ejercicio de poder o contra el poder organizado en torno al eje de dominación y resistencia, la agencia como intención es una "acción cognitiva y emocional orientada hacia un propósito" que, no necesariamente, es consciente pero que se diferencia de las prácticas usuales por ser una acción intencionada.

Las acciones tienen que ver con perseguir metas, proyectos y deseos culturalmente situados, que pueden ser individuales o colectivos. La distinción entre los dos modos de agencia, no implica pensar que en la agencia como intención no están presentes relaciones de poder. En ambos modos de agenciamiento encontramos relaciones de poder. Sin embargo, la diferencia está en que el eje principal en la agencia como intencionalidad no es la resistencia o la dominación sino, lo que pasa por los logros que en un contexto particular se consideran deseables.

Retomando la sanción que se aplicó a la detenida, la misma se inscribe en los legajos criminológicos que son tenidos en cuenta por los jueces para evaluar una posible morigeración de la pena $^{8}$, lo que recae en las detenidas. Son los operadores penitenciarios quienes significan ese hecho pasible de sanción y la aplican, sabiendo que la lectura de dichos legajos por parte de los jueces determina las salidas o no de estas mujeres. Esto evidencia la disciplina, entendida en los términos de Foucault, como proceso de ajuste controlado entre las actividades productivas, los medios de comunicación y el juego de las relaciones de poder. Foucault toma las relaciones a las

\footnotetext{
8 La morigeración de la pena es un instituto por medio del cual se busca atenuar la imposición de la privación de libertad otorgando por ejemplo salidas laborales.
} 
que llama capacidades objetivas (relaciones de poder sobre las cosas) y relaciones de comunicación (relaciones de poder sobre la producción de significados, de signos) para diferenciar aquellas relaciones de poder sobre "los otros". Esta coordinación entre las diferentes relaciones con las prácticas aparecieron resignificadas en palabras de la directora de la Unidad quien decía:

"Nosotros vemos si un nene está limpio, peinando, uno ve porque estamos vigilando, si es bien tratado, entonces siempre convocamos a cambiar la actitud" y agregó "desde el Consejo se apunta a decirles que mejoren [refiriéndose a como ejercían su rol materno] porque sino nosotros tenemos que informar." (Directora de la Unidad Penitenciaria 33)

Observamos como la vigilancia, en tanto táctica del poder disciplinario se encuentra presente. Es la microfísica del poder que menciona Foucault la que se hace visible en los pequeños actos, en las pequeñas acciones. En ese sentido sobre las técnicas inscriptas en las instituciones disciplinarias, Foucault dice:

"Pequeños ardides dotados de un gran poder de difusión, acondicionamientos sutiles, de apariencia inocente, pero en extremo sospechosos, dispositivos que obedecen a inconfesables economías, o que persiguen coerciones sin grandeza, son ellos, sin embargo, los que han provocado la mutación del régimen punitivo en el umbral de la época contemporánea." (Foucault, 1989:142,143)

Además de ser vigiladas en el marco del cumplimiento de una condena, son vigiladas y juzgadas en el ejercicio de la maternidad.

"La madre presa está bajo la lupa y como está presa todos opinan sobre cómo es madre." (Directora del COFam)

Mis preguntas fueron ¿Bajo la lupa de quiénes? ¿Quiénes son todos? Esos "todos", para la directora del COFam es el Estado, "el Estado ausente". encuentra representado por la directora de la Unidad 33, los/as subdirectores, jefes de guardia, de pabellón, profesionales y administrativos/as del Consejo Asistido, docentes, operadores jurídicos. Ahora entonces, cabría repasar los sentidos reificados otorgados al

\footnotetext{
9 "Estado ausente" se desprende de la entrevista realizada a la directora del COFam.
} 
"Estado" por la directora del COFam. A la vez que se excluye de "el Estado ausente" se incluye en un "Estado presente" participando como trabajadora de la Universidad estatal. Ejemplo de ello es su proyecto de extensión universitaria donde, entre otras cuestiones, se pregunta ¿qué es "ser madre" o ejercer la maternidad en el contexto carcelario?

Pude vislumbrar que de una madre se espera que eduque, crie y contenga sacralizando el rol social impuesto. Pero se espera que eduque, crie y contenga de la forma en que ha sido prevista por Occidente atravesando, de modo naturalizado, las prácticas y las representaciones de los sujetos.

Ello también se refleja en los dichos de la jefa de asistencia y tratamiento quien expresó "Otras [mujeres] que están alteradas entonces maltratan al chico, entonces ella la llama aparte a la interna y le dice que el hijo no tiene la culpa. Si tiene que trascender con los jueces también llega, pero no, no hubo esa necesidad."

En efecto, cuando al juez se le presenta alguna cuestión relacionada con la modalidad de ejecución de la condena que tiene para resolver -salida transitoria, arresto domiciliario $^{10}$ - realiza un pedido de informes al lugar donde se encuentra cumpliendo condena la persona sobre quien recae la medida por la cual debe resolver.

En ese sentido, la obstétrica integrante del Consejo Asistido manifestó, que entre otras tareas, el Consejo realiza informes pedidos por los jueces, en donde detallan la vinculación que tienen las madres con sus hijos/as. Y, en base a dichos informes, el juez valorará si otorga, por ejemplo, un arresto domiciliario (sin perjuicio de que pueda tener en cuenta también otras circunstancias como las que trato en el apartado “discriminación subrepticia”). Allí es donde se observa cómo se ejerce el poder de vigilancia en estas instituciones ya que, la posibilidad de que a las mujeres les sea otorgado algún "beneficio" depende de la "evaluación" que realicen los empleados/as del servicio penitenciario respecto de su comportamiento y de su rol materno. Nuevamente se presenta la "docilidad" de los cuerpos a través del ejercicio de la microfísica del poder a la que hice referencia cuando la directora de la Unidad hablaba de vigilancia.

\footnotetext{
10 Sobre este instituto me detendré en el Capítulo 2.
} 
En definitiva, estamos en presencia de una Unidad "típica", en la que las relaciones de poder juegan todo el tiempo, en la cual no sólo se vigila y evalúa el comportamiento de las mujeres detenidas, sino que también se vigila y evalúa el comportamiento reducido al ejercicio del rol materno, el cual no debería ponerse en tela de juicio por no tener que ver con el proceso o condena por el que atraviesan las mujeres en la Unidad.

\subsection{Ellas y "Nosotros". La finalidad del encierro}

En las instituciones totales se observan los sentidos hegemónicos impuestos de un grupo sobre otro. La escisión que se expresa en la construcción de hegemonía da cuenta de distinciones y desigualdades entre los grupos generalmente llamados grupo de interno/a y el grupo supervisor.

Como ejemplo de esta escisión entre grupalidades, fueron esclarecedoras las palabras de la jefa de asistencia y tratamiento quien decía: "ellas tienen sus horarios [...] la relación que hay entre el personal y las internas, nosotros tratamos de correr con esa barrera de que la interna tiene que estar alejada del personal o porque es policía, porque ellos tienen eso, el vocabulario de ellos, nosotros tratamos de romper con esa regla" (el resaltado me pertenece).

Esta entrevista es reveladora de la objetivación del sujeto a través de relaciones que nos constituyen como sujetos capaces de actuar sobre los otros y a la que Foucault (1988), en la segunda parte de su obra "El sujeto y el poder" llamó “prácticas divisorias".

"El sujeto se encuentra dividido en su interior o dividido de los otros. Este proceso lo objetiva. Algunos ejemplos son el loco y el cuerdo, el enfermo y el sano, los criminales y los "buenos muchachos"." (Foucault, 1988:3)

En el marco de la entrevista a la jefa de asistencia y tratamiento y en relación con mi inquietud sobre el modo de subjetivar a las detenidas por parte de los operadores penitenciarios, la entrevistada se refirió a las mujeres como ellos. De algún modo demuestra que no es esperable que una mujer cometa delitos, esté en la cárcel y posea el vocabulario de ellos. Esta masculinización de las detenidas y el ejemplo del vocabulario dan cuenta de lo "inapropiado" que es el ámbito carcelario para una mujer. 
A su vez, tanto el grupo de internas como el grupo supervisor suele representarse al otro a través de estereotipos. El personal suele ver a las internas como "crueles" e "indignas de confianza" y las internas juzgan al personal como "mezquino" y "despótico", así también, el personal suele sentirse superior y justo mientras las internas suelen sentirse marcadas inferiores, débiles y "culpables" aunque, lo de culpable, no se restringe al hecho delictivo del que se las acusa sino, a cuestiones vinculadas con su vida privada en términos de moral.

Una docente del jardín al que asisten los niños y niñas decía:

“[...] Algunas [refiriéndose a las madres detenidas] tienden a ser más violentas que otras, pero no con nosotras, con el personal [...] es distinta la actitud que tienen ellas con el personal que esta vestido de uniforme que con un profesional como nosotros, por ejemplo yo trabajaba en la [Unidad] 8 y [...] ahora me toca verlas y era otro el trato y ahora te respetan, te respetan, cambias de uniforme ${ }^{11} y$ es como que cambia toda la visión de ellas, te hablan de otra manera, no están a la defensiva”.

Ahora bien, ¿cuál es la finalidad del encierro? Conforme la ley de ejecución penal de la Provincia de Buenos Aires la finalidad del encierro es la adecuada inserción social de los procesados y condenados. Sin perjuicio que encierro e inserción social me genera, al menos, un sentimiento contradictorio, la ley establece un sistema progresivo de pena, donde los detenidos o detenidas atraviesan diferentes fases hasta alcanzar su libertad. Sobre el régimen de progresividad de la pena me detendré más adelante.

La finalidad de encierro que estable la ley no resulta tan cercana a la realidad como la dada por Goffman, quien refiere a las cárceles como un tipo de institución "organizado para proteger a la comunidad contra quienes constituyen intencionalmente un peligro para ella $[\mathrm{y}]$ no se propone como finalidad inmediata el bienestar de los reclusos”. (Goffman, 1992:18).

De hecho, la crítica que se realizaba al sistema penitenciario en la primera mitad del siglo XIX no ha perdido vigencia. Dicha crítica apuntaba a la "injusticia" de

\footnotetext{
11 Aparece aquí un significado dado al uniforme como representación eficaz poder, como fetiche, en el sentido de adoración al objeto. El fetiche aparece como la otra cara de reificación del Estado, del Orden dominante, como Genet significa la divisa de Bernadino en "Maleficium: el fetichismo del Estado" (Taussig, 1995)
} 
que los pobres pasaran hambre y frío mientras los presos, quienes eran los "desviados" del sistema comían y tenían una cama donde dormir. Con relación a dicha crítica Foucault (1989:23) escribe "la prisión no es lo suficientemente punitiva: los presos pasan menos hambre, menos frio, se hallan menos privados en resumen que muchos pobres" y entonces "es justo que un condenado sufra fisicamente más que los otros hombres".

Ese pensamiento del S. XIX, y que Foucault toma como eje para pensar la relación entre el sujeto y el poder, no ha quedado olvidado en este siglo y hoy muchos medios de comunicación transcriben este pensamiento y algunas personas que nos rodean concuerdan con este sentido inscripto como "sentido común". La irónica afirmación "es justo que un condenado sufra fisicamente más que los otros hombres” se transforma en realidad.

En ese sentido y al preguntar por los objetivos de la Unidad, teniendo en cuenta que en la región, es la única cárcel que permite la convivencia de las detenidas con sus niños/as, la jefa de asistencia y tratamiento ${ }^{12}$ manifestó:

"El objetivo es que ellas entiendan [...] lo que hicieron, que están pagando su delito acá, que es decisión de la justicia y que nosotros estamos para darle una mano tanto con lo que tienen acá [...] si son sus hijos y entender que afuera hay otras posibilidades, [...] mucho queda por cuestión de la voluntad de cada una de ellas, o sea, a veces cuesta un montón y hay algunas que nunca lo entenderán pero el hecho que ya lo entienda una es suficiente nuestra labor. Es cuestión de cada uno, ¿no? [...] La misión de la institución es obvio si, de que el interno recapacite sobre lo que hizo y qué bueno, que la sociedad lo está esperando y su familia afuera también, que es lo que importa realmente."

De esta entrevista surgen varias cuestiones. Por un lado, la finalidad de la institución no es "tan obvia" como pretende parecer y en la práctica, la finalidad no es la reinserción social sino el "pago" por lo que hicieron, un castigo. Ahora podríamos preguntarnos ¿qué pasa con las mujeres que no están condenadas? ¿cómo rige el

\footnotetext{
12 "La asistencia y tratamiento" estarán dirigidos al fortalecimiento de la dignidad humana y el estímulo de actitudes solidarias inherentes a su condición de ser social, a partir de la satisfacción de sus necesidades y del desarrollo de sus potencialidades. (art. 5 ley 12256)
} 
principio de inocencia? El discurso oficial no distingue entre procesadas y condenadas y esto es un eje a no perder de vista.

Por otro lado, en frases como "la sociedad lo está esperando" y "que el interno recapacite" se revela nuevamente la masculinización y, a su vez, aparece la idea de la mujer incapaz, a quien hay que hacerle comprender que lo que hizo está mal y por ello hay que castigarla. Ella está pagando por lo que hizo.

Esta idea de "mujer incapaz" no está alejada de los sentidos hegemónicos de mujer que atravesó el período 1890-1970 y a la que hace referencia Lila Caimari (2007). Siguiendo a la autora, la mujer era considerada transgresora ocasional resultado de su irracionalidad y falta de inteligencia. Como se puede observar en la entrevista que antecede, la idea de que la mujer es irracional continúa disputando el lugar por la hegemonía. Como si fuera una suerte de esencia, la mujer no puede dar sentido lógico a lo que hizo y, por lo tanto, la cárcel es el lugar donde puede comprender su falta "aunque algunas nunca lleguen a poder hacerlo"-.

Finalmente, retomo de la entrevistada, su discurso pensado por ella como políticamente correcto, donde señala "que la sociedad lo está esperando y su familia afuera también, que es lo que importa realmente", y me pregunto sobre los modos posibles que establece la sociedad y la familia para recibirlas luego de que la vida de estas mujeres quedó literalmente detenida, frenada en el status de presa, del cual resulta muy difícil salir; olvidadas en grises pabellones mientras la vida de otros actores sociales como, la de sus familiares, sigue adelante.

En otra dirección diferente al sentido dado por la jefa de asistencia y tratamiento, la directora de la Unidad entiende que el objetivo de la institución es la resocialización: "así que siempre apuntamos a lo tratamental, que tengan acceso a más cursos, que tengan acceso a micro emprendimientos”, y al ser preguntaba si creía que se cumplía el objetivo manifestó: "Si, si, cuesta mucho conseguir los recursos, pero la voluntad de ellas siempre están abiertas a todas las propuestas. De lunes a viernes de 17 a 19 en la escuela se dan los talleres. Se cuidan entre ellas los nenes, no hay problemática." 
La funcionaria describe como misión de la Unidad la resocialización y la misma entiende por tal lo que enuncia la ley: una cárcel ideal cuya función es la resocialización. La resocialización, conforme a la ley de ejecución de la Provincia de Buenos Aires, supone que se alcanza a través de un régimen de progresividad en el cumplimiento de la pena. La progresividad consiste en que el interno o interna, a través de sus acciones, avance gradualmente a la recuperación de su libertad, por ejemplo, con salidas transitorias hasta llegar a la libertad condicional mediante el cumplimiento de un programa llamado "tratamiento"13.

Sin embargo, el (sin)sentido dado por las mujeres detenidas al objetivo de su paso por la cárcel es otro y coincidente con sus prácticas. Las mujeres tienen dificultades para acceder a los talleres de formación ya que los horarios de los talleres no coinciden con los horarios en que sus hijos/as asisten al jardín de infantes o al jardín maternal. A su vez, no todas las mujeres están dispuestas a dejar a sus niños/as con sus compañeras de pabellón, única solución posible para poder asistir a dichas actividades ${ }^{14}$, según manifestaron. En varias oportunidades expresaron que los cursos no les sirven para el afuera porque no les dan certificado y que tampoco hay capacitaciones para poder llevar adelante algún microemprendimiento a su salida de la cárcel, como por ejemplo, emprender un negocio de peluquería o un negocio de comidas. Estas percepciones muestran como el "tratamiento" se reduce a prácticas sintetizadas en talleres preconcebidos por otros y que no las incluye en su definición; un principio reduccionista y simplificador al que las detenidas deberán adecuarse y resignificar sus vidas en función del discurso que aplica a "qué es lo que importa realmente", como reza el extracto de entrevista presentado más arriba.

\footnotetext{
13 El "tratamiento" es un programa que se les ofrece a las detenidas en donde a través de la realización de diversos cursos de capacitación para oficios o la asistencia a la escuela, se les va reduciendo la pena, conforme la cantidad de horas que asistan a dichas actividades.

${ }^{14}$ Dejar a sus hijos/as con otra compañera está permitido pero implica tener que pedir favores a una compañera y que ésta acepte la responsabilidad que genera cuidar a un niño/a de otra compañera. Conforme lo relatado por una empleada de la Oficina Judicial, con respecto al tema, cree que no hay reglamento y que es una situación que se maneja informalmente. Agrega que además de dejar a los niños/as con una compañera cuando van a los talleres también algunas mujeres lo hacen al ir en comparendo, realizándose un control por parte del Consejo Asistido, quien toma nota y hace una especie de seguimiento. Recordemos que ir en comparendo implica ser trasladada en un camión penitenciario, en el que las mujeres suben a primera hora que ese día se presentan en tribunales en diferentes horarios y direcciones, volviendo a última hora.
} 
En ese sentido, el régimen de progresividad de la pena, se basa en calificar a las detenidas ponderando la realización de tareas laborales, asistencia a cursos de formación o de estudios primarios o secundarios, entre otras opciones. Como lo señalé en el párrafo anterior, las mujeres que conviven con sus hijos e hijas en la Unidad, en muchas ocasiones no pueden asistir a los cursos. De este modo, el régimen de progresividad de la pena se torna discriminatorio para esta colectividad bivalente ${ }^{15}$. Este tipo de discriminación es la llamada discriminación indirecta, a la que yo llamaré discriminación doblemente indirecta, ya que dicha circunstancia afecta también, aunque de modo indirecto, a los hijos e hijas de las mujeres presas. Las mujeres que puedan sostener el régimen de progresividad saldrán en libertad antes que las que no puedan sostenerlo.

Me interesa en este momento recuperar el término "tratamental" que va de la mano de la idea de "tratamiento" y que refleja el pensamiento generalizado de que los/as detenidos/as son una especie de enfermos/as a los/as que hay que rehabilitar. Esta idea remite a los anormales en términos de Foucault. El autor, al describir cómo se instala el discurso médico y judicial en el S. XIX, a través de la utilización de una pieza fundamental, la pericia médico legal, explica cómo dicha práctica crea una nueva categoría: la de anormales. Así la pericia establece una gradación de lo normal a lo anormal y allí es donde despliega todo su "saber" (Foucault, 1988). Detrás de este "saber" se legitiman todas las decisiones respecto a los anormales.

La justificación que encontró el sistema punitivo para seguir existiendo fue la idea de la resocialización. Desde ese presupuesto, la cárcel no es para castigo sino para transformar a las personas. Entran "desviadas", "torcidas" por alguna cuestión que el sistema punitivo no se pregunta, y es ese sistema el que las transforma para vivir en sociedad, las resocializa, las reinserta. Sin embargo, la práctica demuestra que no es así, el encierro está pensado para que "paguen por lo que hicieron", para el castigo. La idea resocializadora a través de trabajos no calificados, por ejemplo, de limpieza es para unas pocas y las pocas que lo consiguen tienen que disputar ese espacio. Esta disputas se expresan en literales peleas cuerpo a cuerpo y se denominan: "ganarse el carnet", situación conocida por la institución.

\footnotetext{
15 Categoría analítica en la que me detendré en el Capítulo 2.
} 
Respecto a ello una de las detenidas relató que no le daban la libertad condicional porque no demostraba estar apta para vivir en sociedad porque no tenía contacto con "la gente". Pensó como hacía para tener trato con la gente estando detenida y quiso entonces conseguir trabajo "en visita", lo que significa atender a los familiares y amigos que van a visitar a las mujeres detenidas. Para conseguir dicho trabajo contó cómo funcionaba ese "sistema":

"Para cada oficio que hay en la cárcel hay un carnet y para ganarse ese carnet hay que pelear, boxear. En 14 años y medio nunca me dieron nada, ninguna salida extraordinaria para ver a mis hijas. Los informes te van a salir mal porque te salen que no estas apta para estar en la sociedad. Ellos te impulsan a que vos busques tu beneficio y no importa como sea, después ellos te llevan al hospital cuando te ven golpeada y sancionan a la que golpeo pero ellos no te dan una solución cuando vos la vas a pedir. Entonces fui y le dije a las chicas que yo estaba buscando mi calle, a la policía no le voy a pedir porque hay ciertos códigos que a la policía no se le va a pedir, la calle me la tengo que ganar yo, entonces le pregunte a las chicas quien era la más nueva y le dije vos y yo vamos a pelear por el carnet y bueno me gane el carnet. Seguí tirando escritos y escritos yo seguía molestando, me decían que no, hasta que un día me dieron la condicional."

A su vez, la educación ${ }^{16}$ pensada en salir del pabellón esporádicamente, tres veces por semana durante una o dos horas, torna a la resocialización en una gran ficción. El ingresar a la cárcel implica adquirir automáticamente el status de "presa", status que subsume los diferentes roles haciendo muy difícil cumplir con la finalidad resocializadora.

\subsection{La discriminación subrepticia. Menores a la cárcel, niños y niñas a sus casas}

El principio de no discriminación es un principio general de los Derechos Humanos receptado en todos los instrumentos internacionales de Derechos Humanos. En consecuencia, dicho principio debe observarse también para los niños y niñas, máxime teniendo en cuenta que el mismo se encuentra regulado específicamente en la Convención Internacional sobre los Derechos del Niño.

\footnotetext{
${ }^{16}$ Educación aquí en sentido formal, es decir, escuela o talleres.
} 
Este principio prohíbe la restricción de derechos fundamentales basada en determinadas condiciones de hombres y mujeres, como la raza, la religión, el género y la nacionalidad, entre otros. Ello no significa que no se deban atender a las características específicas de los niños y niñas, es decir, este principio no implica que deban ser tratados de igual modo que los mayores, sino que debe atenderse a sus especificidades pero sin ser diferenciados en razón de género, raza, religión o nacionalidad.

Retomando lo descripto con relación a los pedidos de arrestos domiciliarios y lo observado en el trabajo de campo, la ley establece la posibilidad de que las mujeres esperen la imposición de la pena o cumplan la misma en su domicilio junto a sus hijos/as. Es decir, la ley es una herramienta fundamental para que los jueces de garantía y/o de ejecución tengan la posibilidad de que, sin dejar de tener en cuenta el interés de la sociedad (es decir aplicar la sanción correspondiente a quien infringe una ley), los niños/as puedan permanecer junto a sus madres fuera de la cárcel.

Sin perjuicio de tener esta herramienta fundamental, muchos jueces deniegan esta posibilidad basándose en situaciones que dejan entrever el origen social de su madre, como por ejemplo, que no puede volver al mismo domicilio en donde cometió el delito o que no tiene arraigo como para asegurar que no se fugará, entre otros fundamentos. Estos fundamentos que hacen eje en sus barrios de origen o en la falta de arraigo se relacionan con las representaciones otorgadas a la pobreza, vista como algo nocivo, siempre vinculado a la carencia, ausencia, promiscuidad, anomia.

Con relación a ello, uno de los jueces entrevistados manifestaba que "La ley prevé la válvula de escape, pero hay un criterio cerrado de los jueces a no darla”. Este criterio cerrado se basa en esas situaciones de volver al mismo barrio, al mismo domicilio vinculando esos lugares con la pobreza. El discurso en tanto práctica, opera entonces como modo prescriptivo. Sin embargo, no es lineal que volver al mismo barrio signifique que se va a volver a transgredir la norma, como así tampoco, que la pobreza sea la causa de la comisión de un delito

Conforme el informe elaborado por la Comisión Provincial por la Memoria, en la denegación de arrestos domiciliarios se combinan dos cuestiones, "Por un lado entra en juego la idea de que existen "carreras delictivas", personas que se encuentran 
(si no biológica) socialmente "inclinadas al delito" y que, por lo tanto, si infringieron la norma una vez volverán a hacerlo. Por otro lado, se recurre al argumento del "riesgo" que permite identificarlas a priori con cualidades "peligrosas" sin necesidad de comprobarlas materialmente sino en su estatus potencial" (Comisión Provincial por la Memoria, 2014: 95).

Estos supuestos plantean la idea de un status de "preso/a". Quien ingresa a la cárcel deja de ser hijo/a, esposa/o, padre/madre, trabajador/a, amigo/a perdiendo no solo la libertad sino también los lazos familiares, el trabajo, las amistades. Esta pauperización penal se naturaliza a través del discurso hegemónico sobre la reincidencia.

En el campo, esta idea de status de "preso/a" se reveló en algunas entrevistas. Por ejemplo una de las que realicé, muy significativa, revelaba que la denegación de los arrestos domiciliarios tenía que ver con los informes ambientales que solicitaba el juez para decidir la concesión o no de los mismos. La entrevistada contaba que:

"uno de los principales factores que creo que hoy está afectando que la gente no se vaya, lo veo con las internas que me dicen, Sra. me llegó el ambiental medio mal. Porque, porque la sacamos de un círculo social donde la persona está afectada por un círculo social, la droga, la delincuencia, porque su mamá está detenida, sus tíos también, sus primos también y el Estado la retrae, la saca, la trata de recuperar, pero luego la queremos volver al mismo circulo donde nació el delito" (jefa de asistencia y tratamiento).

El status de "preso/a" también se evidenció en el encuentro con una "mujer madre" que había estado detenida y había obtenido la libertad condicional gracias a otra compañera detenida que le había ofrecido la casa de sus familiares porque, al salir de la Unidad, no tenía a donde ir.

Sobre estas cuestiones es interesante el análisis que realiza Wacquant en su obra "Las cárceles de la miseria":

"la cárcel no puede sino empobrecer a quienes le son confiados y a sus allegados, al despojarlos un poco más de los magros recursos con que cuentan cuando 
ingresan en ella, suprimir bajo la etiqueta infamante de "preso" todos los status susceptibles de otorgarles una identidad social reconocida (como hijos, maridos, padres, asalariados o desocupados, enfermos, marselleses o madrileños, etcétera) y sumergirlos en la espiral irresistible de la pauperización penal, cara oculta de la "política social" del Estado hacia los más carenciados, naturalizada a continuación por el discurso inagotable sobre la "reincidencia" y la necesidad de endurecer los regímenes de detención." (Wacquant, 2004:143/144).

Las evidentes consecuencias del encarcelamiento hacen muy difícil poder cumplir con los requisitos que exigen los jueces para conceder arrestos domiciliarios.

La jefa de asistencia y tratamiento supo relatar que:

"muchas de las internas no tienen en sus casas ni siquiera la posibilidad que tienen acá, tienen su pañal, su leche, su mamadera, su cuna, me he encontrado con situaciones como que le han dado el arresto domiciliario a una interna, a una mamá con sus dos hijos, y a las dos semanas, tres semanas, vuelvo a encontrármela acá y le digo: ¿violaste el arresto? Y ella me dice: no señora, yo le pedí al juez que me trajera nuevamente porque no puedo estar afuera porque no puedo sostenerlo, no puedo mantener a mis hijos"

En términos de Fraser (1997), de esta entrevista se vislumbran dos tipos de injusticias, la socioeconómica y la cultural o simbólica.

En ese sentido y con relación a los arrestos domiciliarios, nos encontramos frente a la injusticia socioeconómica y en presencia del tipo de discriminación llamada indirecta o de impacto. Dicho concepto aparece por primera vez expuesto por la Corte Suprema de los Estados Unidos en el caso "Griggs vs. Duke Power Co." descripto por Carolina Fernández Blanco. En relación con el caso la autora sostenía que "la compañía de electricidad Duke Power habia instaurado un sistema para el ingreso y promoción de sus trabajadores, consistente en exigir título secundario y/o someterse a dos tests de inteligencia que tenía un claro impacto negativo en el ingreso y/o promoción de los trabajadores de raza negra." (Carolina Fernández Blanco, s.f.:16). Parangonando esto con lo que ocurre con los arrestos domiciliarios que les deniegan a las mujeres, algunos jueces exigen condiciones que la ley no exige; por ejemplo demostrar que van a ir a 
vivir a un lugar diferente del lugar en el que estaban cuando cometieron el delito, y ello repercute negativamente en las personas que poseen escasos recursos económicos porque durante el tiempo que están en la cárcel, no pueden generar recursos suficientes o redes sociales que les permitan conseguir un lugar para vivir fuera del domicilio que tenían al ingresar a la cárcel. $\mathrm{Y}$ en caso de lograrlo, también podría ocurrir que no quisieran mudarse a otro lugar. Exigir que alguien se mude de su residencia de origen es también una clara criminalización de la pobreza.

Lo recién descripto tiene la particularidad de que en el campo se revelan dos colectividades bivalentes interrelacionadas en todo momento: mujeres y niños. En ese sentido lo que le ocurre a las mujeres repercute en los niños y niñas y lo que le ocurre a los niños/as repercute en las mujeres. La denegación de arrestos domiciliarios basados en el origen social de las mujeres pobres afecta a sus hijos e hijas. Esto es lo que doy en llamar discriminación doblemente indirecta, dado que, en definitiva la efectividad de los derechos de los niños y niñas que recoge la $\mathrm{CDN}$, solo vuelve a ser para algunos "niños y niñas" y no para los que encajarían en la categoría de los denominados "menores". 17

Adelanto entonces aquí lo que en profundidad analizo en el capítulo 2, en tanto el tan esperado cambio de paradigma resultó no ser un gran cambio. La recepción de un cambio de normativa, motorizada por la comunidad internacional en la legislación interna, no se corresponde con el cambio esperado de las prácticas "minorizantes".

Asimismo, y volviendo al análisis de la entrevista tomada a la jefa de asistencia y tratamiento surge, como lo adelantara más arriba, la injusticia cultural o simbólica. Al dar por sentado que la detenida había violado el arresto domiciliario da cuenta de una determinada manera de representarse a las mujeres detenidas. Como se puede observar, la entrevistada fundamenta su valoración negativa en la diferencia de supuestos patrones culturales donde, según su mirada evolucionista, dicha diferencia es de grado. En tanto el grado indica la representación de cierto nivel de acopio y de generación cultural, le es posible asumir que ellas no pueden sostener un compromiso asumido. Esta suerte de condescendencia no es más que una forma de irrespeto, una manera de menospreciar a quienes representan otras formas culturales. De lo antedicho

17 Esta diferenciación entre "niños y niñas" y “menores" se desarrolla en el capítulo 2. 
se desprende como la discriminación en razón del género y el origen social, categorías íntimamente relacionadas, atraviesa las representaciones de los operadores institucionales sobre la vida de estas las mujeres impactando, también, en sus hijos/as quienes las acompañan en su suerte y destino.

\subsection{Sumario}

La descripción tanto orgánica como funcional, el análisis de las representaciones sobre esas mujeres, las tramas y las tensiones puestas en juego en la Unidad 33 y la finalidad del encierro en un contexto donde las detenidas conviven en el encierro con sus hijos/as fueron el eje de este capítulo. El mismo se centró en los atravesamientos de las relaciones de poder y agencia presente en las relaciones sociales vivenciadas dentro de la Unidad. En el entramado y tensiones dadas en las relaciones de poder y agencia puestas en juego en esta institución vemos como se desvanece el discurso oficial de la finalidad resocializadora de la misma. Ello se evidencia en las prácticas divisorias, ellas/nosotros las "indignas" y "desviadas"/"dignos" y "derechos" y el dejar de ser mujer, madre, hija, trabajadora, para pasar a tener un "status de presa" que genera que la finalidad resocializadora de la cárcel la alcancen sólo algunas pocas mujeres pero no gracias al encierro sino a pesar del mismo. 


\section{CAPÍTULO 2}

\section{LAS INFANCIAS: LECTURA EN CLAVE DE COLECTIVIDADES BIVALENTES}

En este capítulo analizo la tensión existente entre los discursos y las prácticas que sobre las infancias ${ }^{\mathbf{1 8}}$ están presentes tanto en el viejo paradigma del "Patronato de Menores" como en la nueva doctrina de la "protección integral".

Adelanto aquí que cuando hablo de viejo paradigma hago referencia a aquel que entre sus premisas reivindicaba la intervención estatal para toda aquella infancia definida por sus carencias tanto materiales como simbólicas. Así entendida, la infancia en general pasó a ser la etapa del ciclo vital de "seres inacabados", siendo la "infancia pobre", además, objeto de intervención jurídica, dando sentido a la construcción de la categoría "menor". Cuando me refiero a la nueva doctrina de "protección integral" estoy haciendo referencia a la doctrina surgida en contraposición al viejo paradigma, la cual, entre otros postulados a los que más adelante me referiré, sostiene que las medidas respecto de las infancias deben tener el foco en el niño/a como "sujeto de derechos".

Indago también si este cambio de doctrina, en apariencia copernicano, significó un cambio en las prácticas sobre las intervenciones por parte de directivos y personal de la Unidad 33, del Consejo Asistido y de docentes del jardín maternal respecto de la niñez.

Para analizar esta tensión entre el discurso y la práctica, leeré a las infancias en clave de colectividades bivalentes. Para ello explico porqué hablar de infancias en plural para luego desarrollar los modos de entender y dar sentidos a las mismas a partir de problematizar este colectivo social como colectividad bivalente.

\subsection{Porque hablar de infancias}

Este trabajo intenta romper con las estructuras estáticas y universales de las convenciones sociales y establecer modos de análisis locales y a microescala que permitan identificar las diferentes representaciones sobre las infancias.

\footnotetext{
18 En la presente investigación me refiero de manera indistinta a los términos "infancias", "niñez" y "niñeces", sin desconocer que existen diferencias en cuanto a sus significados en diferentes contextos.
} 
Trato entonces de desterrar el sentido común contemporáneo de la sociedad occidental, que construye a los niños como personas genéricas caracterizadas a partir de valoraciones negativas, esto es, carentes de autonomía, de madurez sexual y de responsabilidad por sus actos. Esta mirada posiciona a dicho colectivo social como objetos pasivos de cuidado, de protección y de educación, en definitiva incompletos y sin capacidad de agencia. Szulc ilumina con un ejemplo sobre el carácter no punible de menores de edad en el sistema penal y en las reacciones de horror ante actos violentos cometidos por niños o niñas cuando señala "la naturaleza pura, inocente y armoniosa que se les atribuye no los habilita para el rol de victimarios sino más bien para el de víctimas." (Szulc, 2006:27).

Como consecuencia de lo dicho, una noción única y estática de infancia no sería demostrativa del universo de experiencias humanas ni de la diversidad de formas, de agenciamiento y representaciones del mundo presentes en los seres humanos en tiempos y espacios también diversos.

Desde la antropología fue Margaret Mead (1990), a comienzos del S. XX, quien cuestionó el carácter universal y natural de las categorías de la adolescencia. En esa línea, conforme Szulc (op. cit.), si bien siempre han existido niños, la niñez relacionada con lo lúdico y lo original no es natural y es a partir de la mitad del S. XX, que los historiadores y otras disciplinas como la antropología y la psicología aportaron al estudio de la niñez desnaturalizando dicha categoría.

La autora destaca que "El origen de la niñez como categoría formal se sitúa, por tanto, en la Europa del S. XVIII. Es en este contexto histórico particular donde se construye socialmente la niñez como un status social especifico, objeto de programas de cuidado, educación y asistencia." (Szulc, 2006:29)

Asimismo, Philippe Ariès ([1960] 1987) caracterizó a la infancia como propia de la sociedad moderna occidental, afirmando que hasta la Edad Media inclusive, los niños eran adultos en miniatura. El autor a través de un recorrido histórico describe los modos en que la infancia era representada en diferentes momentos y cómo esa representación, a su vez, se relacionaba con la manera en que eran representadas las familias. Identifica durante la Edad Media y comienzos de la Edad Moderna a una infancia sin un mundo propio, presente en todo lo relacionado con el mundo adulto, 
compartiendo la vida cotidiana del mismo. No estaba presente el interés por la educación y desde el destete tardío, alrededor de los siete años, los niños/as ya pasaban a realizar las mismas actividades, lúdicas o laborales junto a los adultos. Es a partir de los siglos XIV y fundamentalmente XV y XVI donde se comienza a pensar en la educación para toda la sociedad y aparece la idea de familia moderna, es decir aquella que va más allá de una institución transmisora de bienes y apellidos, y aparece el sentimiento de identidad, de pertenencia a una familia y la preocupación y obligación de parte de los adultos por la educación de todos sus hijos. A su vez el autor realiza un análisis de cómo se fue diferenciando a partir del S. XVIII la educación según las clases. Al decir del autor:

"Las familias burguesas ya no admiten esta convivencia y retiran a sus hijos de lo que pasará a ser la enseñanza primaria popular para meterlos en los internados y en las escuelas menores de los colegios, monopolio de la burguesía. Los juegos y las escuelas, que al principio eran comunes a toda la sociedad, entran en adelante en un sistema de clases." ([1960] 1987:56)

Es interesante recordar aquí lo que plantea Bourdieu (1994) con relación a como la familia pasa a ser la categoría social más natural y ello se debe a que dicha categoría, conforme el autor, funciona:

“como esquema clasificatorio y principio de construcción del mundo social $y$ de la familia como cuerpo social particular, que se adquiere en el seno mismo de una familia como ficción social realizada. En efecto, la familia es el producto de un verdadero trabajo de institución, a la vez ritual y técnico, con vistas a instituir en forma duradera, en cada uno de los miembros de la unidad instituida, sentimientos adecuados para asegurar la integración, que es la condición de la existencia y de la persistencia de esta unidad." (Bourdieu, 1994:3) (El subrayado le pertenece).

Estos sentimientos a los que se refiere Bourdieu, "afectos obligatorios y obligaciones afectivas del sentimiento familiar (amor conyugal, amor paterno y materno, amor filial, amor fraterno, etc.)" (El subrayado le pertenece), son lo que generan una unidad sólida, integrada y estable. El autor concluye que: 
"De este modo, la familia es, ciertamente, una ficción, un artefacto social, una ilusión en el sentido más vulgar del término, pero una "ilusión bien fundada" porque, producida y reproducida con la garantía del Estado, recibe de éste, en cada momento, los medios para existir y subsistir." (Bourdieu, 1994:7)

Vemos como no sólo la categoría niñez/niñeces sino también, otras categorías relacionadas con la infancia como la de familia y educación son categorías que se han ido construyendo a lo largo de la historia y que conforme diferentes contextos son significadas, pudiendo ser abordadas desde la pluralidad y atravesadas por diferentes variables como clase y género, entre otras.

Ya durante el S. XX se observa una construcción diferente de la infancia. La niñez pasa a ser objeto de diferentes disciplinas y sujeta a diversas instituciones. Aquí se hace presente nuevamente la obra "El sujeto y el poder" de Foucault (1988) en cuanto a la objetivación del sujeto pero no ya como lo viéramos en el primer capítulo (en el que hacíamos referencia a las prácticas divisorias), sino a la objetivación del sujeto que Foucault (op. cit.) estudia en su primer obra, es decir la objetivación que transforma a los seres humanos en sujetos a través de modos de investigación que intentan otorgarse a sí mismos status de ciencia. En ese sentido Carli (2006) destaca el concepto de infancia como construcción histórica de la modernidad, centrándose en el papel que ocupó la educación pública. Sin embargo en los últimos años en la Argentina, a partir de los modos en que los medios de comunicación y las tecnologías impactan en los niños/as, aparecen nuevos modos de representaciones de las infancias. En esa línea, la autora pone de resalto diferentes fenómenos que, a pesar de aclarar que en la construcción social de la infancia debe hacerse referencia a las infancias en plural, considera que son comunes a la infancia en general. Estos fenómenos, como los cambios en las estructuras familiares, las tecnologías, el atravesamiento del mercado y de los medios de comunicación hacen que la construcción histórica de la infancia centrada en la familia, la escuela y el Estado, ya no resulte tan eficaz para diferenciar la infancia de la adultez. Asimismo, la exclusión social no distingue generaciones afectando tanto a niños/as como adultos, apareciendo fenómenos como el trabajo infantil, el delito infantil y el niño "de la calle" que indica, al decir de Carli, una autonomía temprana y adultización notoria. 
Tomo prestadas las siguientes palabras de Carli en tanto constituyen un ejemplo palmario de lo que vengo desarrollando:

"Desapareció “nuestra" infancia, la de los que hoy somos adultos, la que quedó grabada en la memoria biográfica, y la de los que advienen al mundo nos resulta ignota, compleja, por momentos incomprensible e incontenible desde las instituciones. Se carece no de niños sino de un discurso adulto que les oferte sentidos para un tiempo de infancia que está aconteciendo en nuevas condiciones históricas." (Carli, s.f.: 2).

Así vemos que cuando hablamos de "menores" nos representamos a aquellos niños y niñas definidos por sus carencias, sin capacidad de agencia y pasibles de intervención de políticas estatales. Cuando escuchamos "niños de la calle" algunos nos representamos a aquellos niños y niñas que se hacen visibles a partir de los años 1990 producto del gran ajuste y empobrecimiento de sus familias. Al escuchar "niño/a consumidor" también nos representamos a la infancia surgida en 1990 producto de la globalización de la economía imperante en aquellos años, que generó un amplio mercado dirigido a la infancia (ropa, juguetes, tecnología). Ello es revelador de los diferentes sentidos dados a las infancias según el contexto histórico, social y cultural en el cual nos situemos.

\subsection{La condición postsocialista y las luchas por el reconocimiento}

A partir de la recuperación de la democracia en la Argentina, la infancia supo encontrar en los movimientos de Derechos Humanos una herramienta fundamental en la instalación de un cambio discursivo que llevó a instaurar una nueva retórica de la niñez.

La lectura en clave de Derechos Humanos y la violación de los mismos a través de determinadas prácticas de intervención estatal sobre las infancias conminó a la búsqueda de nuevas concepciones de políticas públicas de niñez que dejaran atrás las prácticas estigmatizantes sobre la misma.

Tal como lo sostiene Rifiotis "Los Derechos Humanos en Brasil se han convertido en el hilo con el que se teje y se recompone el propio "tejido social", imponiéndose per sé como el elemento central de la agenda política. Los Derechos 
Humanos dan fundamento, coherencia y legitimidad a los movimientos sociales y a las propias politicas públicas." (Rifiotis 2013:4; mi traducción).

Los Derechos Humanos no solo se convirtieron en el fundamento de los movimientos sociales en Brasil, sino que también pasaron a ser el fundamento de los movimientos sociales en Argentina y en toda Latinoamérica.

En efecto, desde el surgimiento del movimiento posmoderno, se instala una nueva concepción en los reclamos de los movimientos sociales comenzando a visibilizarse las luchas por el reconocimiento de la diferencia que encontraron en los Derechos Humanos la manera de alzar sus voces.

Nancy Fraser caracteriza a esta nueva concepción de reclamos políticos como la condición "postsocialista", entendida ésta como "un estado de ánimo escéptico o de un conjunto de sentimientos que marca la situación en la que se encuentra la izquierda después de 1989." (Fraser, 1997:3) y sostiene que:

"estamos presenciando un cambio aparente en el imaginario político, especialmente en los términos en los que se concibe la justicia. Muchos actores parecen distanciarse del imaginario político socialista, en el cual el principal problema de la justicia es el de la redistribución, para adherir a un imaginario politico 'postsocialista', donde el principal problema de la justicia es el reconocimiento. Con este cambio, los principales movimientos sociales ya no se definen económicamente como 'clases' que luchan por defender sus 'intereses', terminar la 'explotación' y lograr la 'redistribución'. Por el contrario, se definen culturalmente 'como grupos' o 'comunidades de valor' que luchan por la defensa de sus 'identidades', por acabar con la 'dominación cultural' y ganar 'reconocimiento'. El resultado es una escisión de la política cultural respecto de la política social” (Fraser, 1997:4)

Haciendo eje en las categorías de redistribución y reconocimiento sostengo que estos "grupos" o "comunidades de valor" que hoy luchan por el reconocimiento de la diferencia son las "clases" que supieron luchar por la redistribución de la riqueza. Ellos encontraron en los Derechos Humanos el fundamento de sus reclamos y lograron su reconocimiento a través de diversos instrumentos internacionales, como la Convención Internacional sobre la Eliminación de todas las Formas de Discriminación 
Racial, la Convención sobre la Eliminación de todas las formas de Discriminación contra la Mujer y la Convención sobre los Derechos del Niño (en adelante CDN), entre otros.

En ese sentido Rifiotis destaca:

"un escenario marcado por luchas sociales y por la "democratización institucional" que hizo converger la multivocalidad de la experticia y de la militancia política generando textos normativos y creando instituciones ligadas a estos, que apuntan al carácter central que ocupan las luchas por el reconocimiento, especialmente, por los derechos en la sociedad contemporánea. Hay “avances” por todos lados, y los Derechos Humanos se tornaron ícono de las luchas sociales. La defensa y promoción de los Derechos Humanos hoy están presentes en los textos normativos y en las instituciones." (Rifiotis, 2013:4)

Sin perjuicio de los avances en términos de reconocimientos de derechos a través de la generación de vastos textos normativos y de la creación de instituciones a tal efecto, siguiendo la tensión entre redistribución y reconocimiento propuesta por Fraser puedo coincidir en que los grupos del reconocimiento de la diferencia que surgen, en un primer momento, para protestar en contra de los "particularismos disfrazados (el machismo, el etnocentrismo del blanco anglosajón, el heterosexismoocultos tras la parodia del universalismo" (Fraser, 1997:9) son, a su vez, los grupos social y económicamente más desprotegidos. Ello porque las injusticias que reflejan tanto las luchas por la redistribución como las luchas por el reconocimiento encuentran su origen en la estructura industrial del capitalismo basada en un orden de género, en el que el hombre era el único proveedor y la mujer la única cuidadora. En ese sentido la autora sostiene que:

"Se suponía que las personas estaban organizadas en familias nucleares heterosexuales encabezadas por un hombre, cuya principal fuente de ingreso era el salario del hombre en el mercado de trabajo. El hombre cabeza de familia recibía un salario familiar, esto es, un salario suficiente para mantener a los hijos y a una esposay-madre de tiempo completo, quien se dedicaba al trabajo doméstico de tiempo completo, sin recibir ninguna remuneración. Desde luego, las vidas de muchas 
personas nunca se ajustaron a este patrón; aun así, ésta era la representación normativa de lo que debía ser la familia correcta." (Fraser, 1997:56).

En el caso en que las mujeres no se dedicaran a tiempo completo al ámbito doméstico, los trabajos asignados culturalmente a ellas fueron y son, remunerados con salarios más bajos que los trabajos culturalmente asignados a los hombres. De este modo las mujeres además de luchar por el reconocimiento de una identidad cultural deben luchar por la igualdad social, al igual que ocurre con otros grupos históricamente postergados. Estos grupos o colectividades bivalentes al decir de Fraser, tales como las mujeres, los pueblos originarios, las minorías raciales y étnicas que han luchado por la igualdad económica, hoy lo hacen por el reconocimiento.

La niñez, como categoría, a través de instituciones filantrópicas primero y de organizaciones internacionales después, también hizo escuchar su voz y no fue ajena al surgimiento de los "grupos" de reconocimiento. Este recorrido entre la época industrial capitalista y la condición postsocialista a la que hace referencia Fraser para analizar el surgimiento de los grupos del reconocimiento, me sirvió para visualizar que las infancias no fueron ajenas a dicho recorrido y pasaron de ser un colectivo social meritorio de las luchas por la redistribución a un colectivo apreciable en las luchas por el reconocimiento. Ello me insta a analizar en el apartado siguiente las prácticas imperantes durante la doctrina de la "situación irregular" y de la "protección integral" sobre las infancias analizadas desde el marco conceptual de las colectividades bivalentes.

\subsection{De la situación irregular a la protección integral}

Para indagar los significados de la nueva doctrina de la protección integral, analizo el contexto que posibilitó que las luchas por el reconocimiento de los movimientos sociales encontraran el espacio adecuado para instalar una nueva doctrina, traducida en nuevas legislaciones e instituciones de construcción de infancias desde una perspectiva más respetuosa y adecuada a los tratados internacionales de Derechos Humanos. 
Para ello, también indago sobre las representaciones de las infancias existentes durante la llamada gran inmigración en nuestro país, representaciones que posibilitaron el dictado de la ley 10.903 conocida como ley del Patronato de Menores.

Cabe señalar que hasta la llegada de la gran inmigración a nuestro país en el año 1880 , la cuestión de las infancias no fue un tema en la agenda pública. La infancia pobre y desvalida era un asunto del que se ocupaban sectores de la sociedad civil o religiosa, vinculándose siempre la protección de los niños y niñas con la internación en instituciones llamadas "reformatorios", "ya que de la otra infancia se ocupaban sus propias familias" (Mary Beloff, 2005: 770). (El subrayado me pertenece).

Los niños pobres eran sinónimo de menores. En una primera etapa eran los hijos de aquellos inmigrantes que habían conformado la clase obrera y posteriormente se dirigió a la infancia urbana pobre. Los menores "eran los <hijos de la mala vida>o de vidas dudosas. Los hijos de los pobres y de los revoltosos, los hijos de los extranjeros-extraños de la Europa pobre”. (Daroqui y Guemureman, 1999:17). Más adelante, con el advenimiento del Estado de Bienestar, fueron conformándose las denominadas villas de emergencia y los menores pasaron a ser los hijos de aquellos nuevos pobres que vivían en dichos asentamientos.

Pero volviendo al gran crecimiento demográfico de las ciudades, principalmente Buenos Aires, por la llegada masiva de inmigrantes, muchos de ellos "anarquistas y socialistas" y el surgimiento del movimiento obrero, también crece la idea de las grandes ciudades como "peligrosas". A su vez, comienza a instalarse el relato de que los hijos pequeños de aquellos inmigrantes eran potenciales “delincuentes". Muchos niños y niñas permanecían gran tiempo en las calles y ello se visibilizó como un "problema” para el modelo de familia que se imponía. Se relacionó el estar en las calles con la "vagancia" y la "vagancia", a su vez, se relacionó con la delincuencia.

Nari, con relación a ello, refiere que:

"El problema que acuciaba por entonces eran los niños y las niñas en la calle. La calle asociada a la "vagancia" (aún cuando se trabajara en ella) y la vagancia a la delincuencia. Estos niños y niñas generalmente tenían una familia, 
aunque muy alejada del modelo nuclear y habitacional naturalizado. [...] La presencia de estos niños y niñas en la calle fue pensada desde el "abandono material y moral", el "peligro moral" y se constituyeron en amenazas al "orden" social, "racial" y nacional. La "vagancia”, percibida en íntima conexión con la delincuencia, constituyó uno de los detonantes más claros para una "legítima” intromisión del Estado en la "privacidad" de las familias y el despojamiento de la patria potestad." (Nari, 2004:210)

En ese sentido, el diputado argentino Agote (quien fue el autor del proyecto que luego se convertiría en la ley 10.903) decía:

“... la causa por qué encuéntrense en estas reuniones anarquistas tan gran cantidad de niños delincuentes, los que, abandonados en las calles de Buenos Aires, vendiendo diarios primero y después siguiendo, por una gradación sucesiva en esta pendiente siempre progresiva del vicio, hasta el crimen, van más tarde a formar parte de esas bandas de anarquistas que han agitado a la ciudad durante el último tiempo." (Luis Agote en: Zapiola, María Carolina: 2010:7).

Los inmigrantes y sus hijos eran representados como delincuentes y el trabajo de esos niños los convertía en niños "abandonados".

"La ciudad encarnaba simbólicamente todos los peores aspectos de la vida industrial moderna. No era un lugar adecuado para la inocencia del niño, y debilitaba, corrompía, equivocaba y mancillaba a la juventud.” (Anthony Platt 2001: 64).

En ese contexto se dicta la Ley de Patronato de Menores 10.903, promulgada en el año 1919. Dicha ley reguló la aplicación de políticas tutelares en sentido de "protección" para aquellos niños/as en "situación de peligro moral o material"; esto es lo que se conoció como "situación irregular", transformando automáticamente a todos los niños y niñas que se encontraban pasando por alguna situación descripta como objeto de protección, en "menores".

Tal como lo sostienen Daroqui y Guemureman (1999), de la definición de niño en situación de peligro moral y material surgen dos figuras dominantes, "el niño abandonado" y "el niño delincuente" a quienes hay que "tutelar" o "corregir", a través 
del régimen tutelar (intervención estatal o instituciones de beneficencia) o por el modelo correccional recién instaurado.

"En el discurso de los "empresarios morales" de aquellos años, no había diferencia entre ellos, el niño abandonado seguramente terminaría delincuente, y el niño delincuente seguramente fue primero un niño abandonado. No había escapatoria para algunos niños, muchos niños, ¿qué niños? Los hijos de los pobres, de aquella "multitud de pobres", inmigrantes y obreros que irrumpian e instalaban por primera vez el tema de la pauperización en la agenda política de los representantes del orden social dominante." (Daroqui y Guemureman, 1999:4).

A su vez, la ambigüedad del término "protección" fue la que dio lugar a diversas interpretaciones, sosteniendo y amparando "prácticas, discursos y políticas que [...] han promovido el proceso de minorización de un amplio sector de la niñez." (Daroqui y Guemureman, 1999).

El sentido dado a la "protección" de "los menores" fue la desvinculación de su grupo doméstico y su institucionalización a fin de "educarlos" como se esperaba que debían ser educados, es decir, formados para un trabajo "digno", no para estar "mendigando" y "vagueando" por la calle vendiendo periódicos.

Quiénes debían ser objetos de "protección" surge de la propia ley que definió qué se entendería por "material o moralmente abandonados o en peligro moral", y en su art. 21 dispuso:

"A los efectos de los artículos anteriores, se entenderá por abandono material o moral, o peligro moral, la incitación por los padres, tutores o guardadores de la ejecución por el menor de los actos perjudiciales a su salud física o moral; la mendicidad o la vagancia por parte del menor, su frecuentación a sitios inmorales o de juego, o con ladrones, o gente viciosa o de mal vivir, o que no habiendo cumplido 18 años de edad, vendan periódicos, publicaciones u objetos de cualquier naturaleza que fueren en las calles o lugares públicos, o cuando en estos sitios ejerzan oficios lejos de la vigilancia de sus padres o guardadores, o cuando sean ocupados en oficios o empleos perjudiciales a la moral o a la salud." 
A través de este discurso, se legitimaron decisiones que en pos del bienestar de niños y niñas restringieron, tanto en el caso del "niño abandonado" como del "niño delincuente" diversos derechos tales como el derecho a permanecer con su familia o garantías del debido proceso legal.

A su vez, la imprecisión de los conceptos, como por ejemplo "actos perjudiciales a su salud física o moral" y "ocupados en oficios o empleos perjudiciales a la moral o a la salud", posibilitó la aplicación de prácticas discrecionales por parte de los organismos del Estado, como por ejemplo la desvinculación de sus familias.

Con relación a los reformatorios se argumentaba que no eran cárceles, sino hogares donde aprendían a ser "buenos ciudadanos":

"no es de ninguna manera una prisión, ya que no tiene barrotes ni cerrojos; en su lugar, los muchachos son gobernados por el amor y la amabilidad, ya que nuestro objetivo es cultivar en ellos los buenos modales, la limpieza personal, el lenguaje decente, los hábitos de laboriosidad y la apreciación de las buenas costumbres y la actividad, con el fin de capacitarlos para entrar en hogares donde puedan hacerse hombres y adquirir las cualidades del buen ciudadano.” (Platt, 2001:131).

La finalidad de los mismos, desde el discurso oficial era reformar, no castigar, mediante la enseñanza de los valores del "trabajo", del "respeto" y la "honra". Sin embargo, este espacio se convirtió en un lugar de hacinamiento corrompido por la mala gestión y la falta de recursos económicos. "La represión y la disciplina eran partes integrantes del programa de "tratamiento" [...] y las largas horas de trabajo tedioso eran la esencia del plan de reformatorios" (Platt, 2001: 95).

Este paradigma entra en crisis dejando el espacio propicio para que las voces "representativas" de las infancias, como otros grupos de reconocimiento fueran escuchadas y comience un nuevo paradigma basado en instrumentos internacionales de Derechos Humanos abriendo, en nuestro país, una nueva etapa en materia de niñez.

De este modo, a través de la construcción social de un nuevo niño/a y en consecuencia de una nueva doctrina de intervención estatal se inició un nuevo camino que, al menos, en términos discursivos incluía a todos los niños y niñas de la Argentina. 


\subsection{La transformación subjetiva}

En el año 1994 con la reforma de nuestra Constitución Nacional se incorporan a la misma varios tratados internacionales, entre ellos la $\mathrm{CDN}$, adquiriendo jerarquía constitucional. Con ello, las luchas por el reconocimiento, de alguna manera, ganaron una batalla al lograr instalar fuertemente el discurso del nuevo paradigma.

La CDN establece en su articulado, entre otros, el derecho a la vida, a la dignidad, a la integridad personal, a la educación, a la salud, derecho al juego recreativo, el respeto al pleno desarrollo personal de sus derechos en su medio familiar, social y cultural, y la ley nacional 26.061 agrega que las medidas de protección integral se extenderán a la madre y al padre durante el embarazo, al parto y al período de lactancia garantizando condiciones dignas y equitativas para el adecuado desarrollo de su embarazo y la crianza de su hijo/a y a la preservación de sus relaciones familiares.

Los niños, niñas y adolescentes menores de dieciocho años son los titulares de dichos derechos, dejando de ser objetos de protección para ser sujetos de derechos, siendo considerados personas en crecimiento y siendo la familia el grupo fundamental para su desarrollo y bienestar.

El cambio de paradigma, es decir, la sustitución de la doctrina de la "situación irregular" por la doctrina de la "protección integral" significó dejar de hablar de "menores" para pasar a hablar de niños, niñas y adolescentes. La CDN se dirigió a toda la infancia como sujetos plenos de derecho, es decir, personas completas y capaces, titulares de dichos derechos. En definitiva, un reconocimiento de todos los Derechos Humanos de los que gozaban los adultos para todos los niños y niñas, pensados como sujetos de derechos aunque con una protección especial por ser personas en crecimiento. Esta protección especial está constituida por un plus de derechos que les son propios (principio del interés superior del niño/a, derecho a ser oído, a crecer en su grupo familiar, derecho al juego recreativo, entre otros). Tal como señala Beloff:

"La pregunta es, entonces, qué significa ser sujeto de derecho en el marco de la Convención. Significa [...] ser titular de los mismos derechos que gozan todas las personas más derechos específicos que surgen de la condición de persona que está creciendo. Ni media persona ni persona incompleta ni incapaz, simplemente se trata de 
una persona que está creciendo. Las personas son completas en cada momento de su crecimiento. " (Beloff 2005: 105)

Varias provincias argentinas, en los años siguientes de haberse aprobado la CDN dictaron leyes en materia de infancia o adecuaron las leyes existentes a los estándares de la misma. ${ }^{19}$

Particularmente, en la Provincia de Buenos Aires, dicha adecuación generó una gran resistencia por un conflicto de poderes entre el Ministerio Público de la Provincia de Buenos Aires y los municipios por determinadas competencias relacionadas con medidas de protección de niños y niñas como por ejemplo, el otorgamiento de programas, planes y servicios para proteger y/o restablecer los derechos del niño/a; recibir denuncias o actuar de oficio cuando aparecían amenazados o violados sus derechos. Esto produjo que se tardaran diecisiete años en dictar una ley de conformidad con los estándares internacionales en materia de infancia.

En ese sentido la ley 12.607, que había sido aprobada en el año 2000 por unanimidad en la Legislatura de la Provincia de Buenos Aires, fue suspendida por una medida cautelar ${ }^{20}$ dictada por la Suprema Corte de Justicia de la Provincia de Buenos Aires a pedido del Ministerio Público de la Procuración General de la Suprema Corte de Justicia de la Provincia de Buenos Aires.

Con respecto a dicha medida cautelar Beloff decía:

“... medida cautelar que se extendió por más de dos años sin que se resolviera sobre el fondo del asunto. El conflicto, básicamente, se reducía a la desjudicialización propuesta por la ley de algunas cuestiones vinculadas con la protección a los niños. En la práctica, ello significó que los Tribunales de Menores de la provincia continuaran aplicando el Decreto-ley $n^{\circ} 10.067$, retuvieran las competencias asistenciales - transferidas por la nueva ley a los municipios-y no aplicaran los derechos y principios emanados de la Convención... mientras la

\footnotetext{
19 Mendoza en año 1995, Chubut en 1997, CABA en 1998, Santa y Neuquén en 1999, Tierra del Fuego en el 2000 y San Juan en el 2002 fueron las primeras provincias en adecuar la legislación en materia de infancia a la CDN.

20 La medida cautelar apuntaba a la suspensión de los efectos de la ley hasta tanto se resolviera la acción de inconstitucionalidad planteada por el Procurador General de la SCBA, respecto de varios artículos de la ley.
} 
Legislatura siguió aprobando leyes que prorrogaban la vigencia del Decreto-ley $n^{\circ}$ 10.067 ..." (Beloff, 2008:23).

En el año 2005, se dictó una nueva ley en el ámbito de la Legislatura de la Provincia de Buenos Aires, la número 13.298 llamada "Ley de Promoción y Protección Integral de los Derechos de los Niños" que derogó el decreto-ley 10.067/83 y la ley 12.607, y a un día de su entrada en vigencia, fue suspendida ${ }^{21}$ como la ley anterior, por un pedido de la Procuración General de la Suprema Corte de Justicia de la Provincia de Buenos Aires (SCJBA de aquí en más), al que dicha Corte hizo lugar.

Un año después, en diciembre de 2006, la legislatura de la Provincia de Buenos Aires dictó la ley 13.634, estableciendo los principios generales del fuero de familia y del fuero de responsabilidad penal del niño. De este modo, la SCJBA declaró abstracta la cuestión y la ley 13.298 entró en vigencia.

Estas diferencias entre diversos poderes de la Provincia de Buenos Aires por la asignación de competencias y distribución de recursos económicos hicieron que los problemas sociales representados por las infancias tuvieran que esperar diecisiete años para tener una ley de conformidad con el nuevo paradigma, que de nuevo, ya tenía muy poco.

A nivel nacional se dictó en el año 2005, la ley 26.061 de Protección integral de los derechos de las niñas, niños y adolescentes, que a quince años de la puesta en vigencia de la CDN ya no parecía necesaria por varias cuestiones. Una de ellas atiende a que su técnica legislativa es deficiente al contener cuestiones de competencia no delegadas por las provincias, máxime cuando muchas provincias ya habían dictado sus propias leyes; otra cuestión, porque recepta conceptos ambiguos de la CDN (como por ejemplo el interés superior del niño), que ya estaban siendo cuestionados luego de haber pasado la fascinación por dicho instrumento internacional y por último, siguiendo a Grosman (1993), porque los derechos consagrados en los tratados internacionales, en este caso, en la CDN son operativos, es decir, no es necesaria otra ley aparte de la ley que ratifica el tratado para que los mismos tengan

\footnotetext{
${ }^{21}$ La ley13.298 fue suspendida por otra medida cautelar planteada por la Procuración General de la Provincia de Buenos Aires, quien solicitó ante la SCBA la suspensión de la ley alegando entre otras cuestiones la falta de reglamentación y articulación para la transición.
} 
ejecutoriedad. Sin perjuicio de ello, el dictado de la ley 26.061, vino a cerrar simbólicamente la etapa de la doctrina de la "situación irregular".

Ahora bien, más allá de la normativa señalada en este acápite, como ha señalado Diker (2009) la protección de las infancias exige algo más que la sanción de leyes, exige un conjunto de políticas sociales y redes institucionales por fuera de la lógica judicial, una reestructuración del poder judicial en materia de infancias y cambios en las representaciones sobre las mismas.

En relación con la advertencia ofrecida por Diker (op. cit.) me propuse problematizar la legislación que regía antes del cambio de paradigma y los modos de adecuación de las leyes a la doctrina de la protección integral. En ese contexto y en íntima relación con mi trabajo de campo surge la primera pregunta de conocimiento: ¿Cómo operan los cambios legislativos en las decisiones de los operadores de la justicia de ejecución penal en el caso de los niños y niñas que viven el encierro de sus madres? En particular, cuáles son las representaciones y qué prácticas producen dichas representaciones en los distintos actores sociales del pabellón 10 de la Unidad 33 de La Plata.

\subsection{De los "menores" de ayer a los "niños" de hoy}

A partir de la CDN se impone una nueva concepción del niño/a como ciudadano titular de derechos que, como destaca Gabriela Diker, "altera sustantivamente el modo en que el niño se hace presente en el territorio público y, por lo tanto, el lugar que el Estado debe ocupar para asegurar su protección" (Diker, 2009:33)

A través del nuevo paradigma, el Estado es interpelado para garantizar que todos los niños y niñas, ahora "sujetos" de derechos, puedan ejercerlos. Esa garantía implica, entre otras cuestiones, que no se judicialice, por ejemplo, la situación de pobreza. Esto significa que no se debe aplicar lo que se denomina "criminalización de la pobreza", esto es, sancionar por origen social y no por una acción, debiéndose diferenciar las cuestiones asistenciales (educación, salud) de las judiciales (guarda, adopciones, comisión de un delito). Asimismo, la familia debe ser el ámbito fundamental para el desarrollo del niño/a, debiendo el Estado implementar políticas que 
posibiliten dicho desarrollo en el grupo doméstico, a fin de que el origen social no impida el ejercicio de derechos a todos los niños y niñas.

Sin embargo, como sostiene Diker, "el hecho de que el discurso de los derechos haya ganado espacio y que la utilización del término “menor" esté en retroceso no significa que las miradas y las prácticas minorizantes hayan desaparecido." (Diker, 2009:41)

La pregunta que surge inevitable, es si la propuesta discursiva de la nueva doctrina de la protección integral produjo cambios capaces de ser expresados en las representaciones y prácticas penitenciarias y en las de otros actores involucrados con los casos de niños y niñas que viven el encierro carcelario de sus madres, como es el caso de la Unidad 33 de La Plata.

Como ya señalara más arriba, la categoría "menor" se construyó para ser dirigida a los hijos de quienes estaban excluidos del sistema imperante a principios del Siglo XX; en un primer momento los menores fueron los hijos de los inmigrantes y posteriormente fueron los hijos de aquellos que vivían en las villas miserias: los nuevos pobres.

A lo largo de la investigación y de las entrevistas realizadas surgió que los ahora llamados de modo "políticamente correcto" niños, "gorditos", "criaturas" no son más que aquellos "menores", hijos e hijas de los denominados excluidos del sistema, otros pobres. No es casual que en el marco de una entrevista, una profesional del CA a modo de confesión, y casi como si fuera un secreto - recuerdo que inclinó su cuerpo hacia adelante acercándose a mí - y asegurándose de que no estuviera grabando, en voz baja me dijo: "acá son todas pobres pero nunca te lo voy a decir mientras me grabes".

Debo decir que no me llamó la atención su "casi" revelación teniendo en cuenta que es públicamente conocido y existen numerosas publicaciones que revelan que, en los establecimientos penitenciarios, la mayoría de las personas privadas de su libertad son pobres. La Unidad 33 no es un caso aislado a todo el sistema penal y las mujeres que están allí privadas de su liberad, en general, son pobres, siéndolo también sus hijos e hijas. En este punto vemos entonces como, en cuanto a no criminalizar la 
pobreza de niños y niñas, el cambio de paradigma ha quedado en una declaración de buenas intenciones.

Ahora bien, tanto la ley de ejecución penal de la nación como de la Provincia de Buenos Aires previeron una alternativa a la prisión para aquellas personas que la ley considera vulnerables (enfermos, personas mayores de setenta años, mujeres embarazadas y mujeres con hijos menores de cincos años).

En el año 2009, a nivel nacional, se modifica le ley 24.660 a fin de regular el régimen de medidas alternativas de prisión y en consecuencia, el art. 32 queda redactado, en lo pertinente, del siguiente modo: "El Juez de ejecución, o juez competente, podrá disponer el cumplimiento de la pena impuesta en detención domiciliaria: [...] e) A la mujer embarazada; f) A la madre de un niño menor de cinco (5) a $\tilde{n} o s . . . "$

En los fundamentos de dicha ley se exponía que el ámbito carcelario, más allá de la deficiente infraestructura de las instituciones penitenciarias de nuestro país y la constante interacción violenta, de por sí es inadecuado para alojar a ciertas personas "vulnerables" (como por ejemplo personas mayores o mujeres embarazadas). En ese sentido la prisión domiciliaria es la posibilidad de cumplir la sanción penal fuera del ámbito carcelario, sosteniendo que uno de los valores que está en juego y se quiere preservar es la salud y el derecho a la vida.

Específicamente con relación a mujeres embarazadas y niños/as, los fundamentos sostienen que la sanción no debe trascender al individuo responsable penalmente. Esto refiere al principio de instrascendencia penal, el cual sostiene que la sanción no puede afectar a otras personas que no sean aquellas sobre las que recae la misma, es decir, no puede "pagar" una persona por los actos que comete otra.

Asimismo y con respecto al contacto con la madre en los primeros años de vida los fundamentos sostienen:

"el contacto con la madre en los primeros años de vida resulta fundamental para el desarrollo de los niños. Por eso mismo, se procura mantener unidos a la madre del niño existiendo dos opciones legislativas: la primera es la privación de la libertad de la madre y el niño (la más frecuente en los órdenes jurídicos latinoamericanos) y la 
otra opción es disponer la prisión domiciliaria de la madre. Evidentemente, la primera opción implica la privación de la libertad de un niño, sometiéndolo a las consecuencias lesivas de un proceso de institucionalización, sólo para garantizarle su contacto con la madre. Consideramos que para estos supuestos existen medidas menos restrictivas de la libertad para el niño como la prisión domiciliaria garantizando tanto el cumplimiento de la pena y el contacto madre hijo." (Cámara de Diputados de la Provincia de Buenos Aires).

A través de dicha ley también se modificó el art. 10 del Código Penal Argentino que actualmente establece en lo que aquí nos interesa que, a criterio del juez competente, podrán cumplir la pena de reclusión o prisión en detención domiciliaria la mujer embarazada y la madre de un niño menor de cinco (5) años.

En cuanto a medidas alternativas de prisión, la ley de ejecución penal bonaerense 12.256 (y sus modificatorias), en su art. 19 también regula la detención domiciliaria disponiendo que la mujer embarazada y la madre de un niño menor de cinco (5) años podrán solicitar dicha modalidad de detención. Por su lado, el Código Procesal Penal de la Provincia de Buenos Aires establece en su art. 159 que:

“... cuando se tratare de una mujer en estado de gravidez o con hijos menores de cinco (5) años y siempre que el peligro de fuga o de entorpecimiento probatorio pudiera razonablemente evitarse por aplicación de otra medida menos gravosa para el imputado, o de alguna técnica o sistema electrónico o computarizado que permita controlar no se excedan los límites impuestos a la libertad locomotiva, el juez de garantías impondrá tales alternativas en lugar de la prisión, sujeta a las circunstancias del caso, pudiendo establecer las condiciones que estime necesarias."

Y en el art. siguiente establece que:

"Entre otras alternativas, aún de oficio y con fundamento suficiente, podrá disponerse la libertad del imputado sujeta a una o varias de las condiciones siguientes, de acuerdo a las circunstancias del caso: 1.- La obligación de someterse al cuidado de una persona o institución, quién informará periódicamente a la autoridad. 2.- La obligación de presentarse periódicamente ante la autoridad que se designe. 3.- La prohibición de salir de un ámbito territorial determinado, de concurrir a determinados 
lugares, o de comunicarse con ciertas personas. 4.- La prestación de una caución patrimonial por el propio imputado o por otra persona. 5.- La simple promesa jurada de someterse al procedimiento penal, cuando con ésta bastara como alternativa o fuere imposible el cumplimiento de otra. ...."

Sin embargo, las experiencias relevadas nos muestran que, a pesar de la normativa arriba citada, el origen social determina, en definitiva, quién puede sostener el cumplimiento de un arresto domiciliario y quién no. Aquella que tenga una red de contención y recursos materiales y simbólicos podrá sostenerlo y aquella que no, deberá cumplir su condena en la cárcel; en consecuencia, la norma, sin hacerlo explícito excluye de este derecho a una parte del universo de personas detenidas y por transferencia a una parte de la infancia.

Más arriba hice mención a lo que se denomina red de contención. Conforme los sentidos dados por los efectores judiciales (jueces, defensores), hago referencia a la presencia de un familiar, un/a vecino/a, alguna ONG que apoye a la mujer que solicita un arresto domiciliario, ya sea ayudándola a realizar algún tipo de tarea comunitaria o a ofrecer un teléfono de referencia. Con relación a esto, el juez de ejecución entrevistado explicaba que existía la posibilidad de denegar el arresto domiciliario si la detenida no tenía recursos económicos ni una red de contención que le sirva de sostén o apoyo.

De lo relatado se infiere cómo se naturaliza en los distintos sujetos la pobreza en las cárceles. Esta naturalización de la pobreza en la Unidad de referencia se relaciona con un discurso legitimador del poder punitivo como control social. El poder punitivo opera selectivamente criminalizando conforme estereotipos.

Zaffaroni recordando la obra de Lombroso relata:

"la obra de Cesare Lombroso, que describe lo que vio en las cárceles y manicomios de su tiempo, es en definitiva la mejor descripción que se ha hecho de todas las discriminaciones traducidas en estereotipos criminales (selectivos). Nadie con las características que describió Lombroso podía quedar indemne al poder punitivo de la época” (Zaffaroni, 2000:28).

En el mismo sentido que la obra de Lombroso podemos señalar la política de "tolerancia cero" instalada en Nueva York, EE.UU. durante los años 1990. Dicha 
política $^{22}$, que pretendió aplicarse en Latinoamérica y específicamente en la Argentina, con la visita en los años 1999 y 2000 del ex jefe de policía de Nueva York, William Bratton, estuvo dirigida a establecer políticas punitivas contra las consecuencias del delito como si fueran las causas. La frase "La causa del delito es el mal comportamiento de los individuos y no la consecuencia de condiciones sociales", echó por tierra el resultado de años de investigaciones. ${ }^{23}$

Diversas investigaciones concluyen que quien realiza una conducta tipificada por el derecho penal como delito, en general lo hace luego de haber atravesado un proceso previo de exclusión. Sin embargo la política de "tolerancia cero" sostenía:

"Por mínimas que parezcan, las primeras conductas desviadas, apenas se generalizan, estigmatizan un barrio, polarizan en él otras desviaciones, son la señal de que se acabó la paz social cotidiana. Se pone así en marcha la espiral de la decadencia, se instala la violencia y con ella todas las formas de delincuencia: agresiones, robos. ”(Wacquant 2004:58)

Tal como lo sostiene el criminólogo Adam Crawford transcripto por Wacquant deberíamos llamar a ésta política como “intolerancia selectiva"24. E1 criminólogo escribe lo siguiente:

\footnotetext{
${ }^{22}$ Para comprender a donde se dirigen los postulados de la doctrina de la "tolerancia cero" Wacquant transcribe las palabras de Bratton en una de sus conferencias: "En Nueva York sabemos dónde está el enemigo", declaraba Bratton en una conferencia realizada en la Heritage Foundation, otro gran think tank neoconservador aliado al Manhattan Institute en la campaña de penalización de la pobreza: los squeegeemen, esos individuos sin techo que acosan a los automovilistas detenidos ante los semáforos para ofrecerse a lavar sus parabrisas a cambio de unas monedas (el nuevo alcalde, Rudolph Giuliani, había hecho de ellos el símbolo vergonzoso de la decadencia social y moral de la ciudad, y la prensa popular los asimila abiertamente a parásitos: "squeegee pests "), los pequeños revendedores de droga, las prostitutas, los mendigos, los vagabundos y los autores de graffiti. En síntesis, el subproletariado que representa una mancha y una amenaza. A él apunta prioritariamente la política de "tolerancia cero" que aspira a restablecer la "calidad de vida" de los neoyorquinos que, por su parte, saben comportarse en público." (Wacquant, 2004:29)

${ }^{23}$ En ese sentido Wacquant al describir la visita de Bratton a la Argentina decía "En enero de 2000, llegó incluso a visitar furtivamente dos de los barrios de mala fama, Pompeya y Barracas, donde se acumulan la desocupación, la miseria y el crimen. El año anterior ya había afirmado, con magnífico aplomo (puesto que es policía de oficio y no sociólogo, criminólogo o economista), que "la desocupación no está relacionada con el delito". En el nuevo milenio va aún más lejos y, con la experiencia que le dan tres años escasos pasados a la cabeza de la policía de Nueva York, barre con una frase los resultados de décadas de investigación: "La causa del delito es el mal comportamiento de los individuos y no la consecuencia de condiciones sociales" (Wacquant, 2004:11)

24 "Un minucioso estudio estadístico del uso de la técnica del "stop and frisk", medida emblemática de la "tolerancia cero", consistente en controlar, detener y en caso de necesidad someter a un cacheo en la calle
} 
"El concepto de "tolerancia cero" es una designación errónea. No implica la rigurosa aplicación de todas las leyes, que sería imposible -por no decir intolerable-, sino más bien una imposición extremadamente discriminatoria contra determinados grupos de personas en ciertas zonas simbólicas. ¿Dónde está la 'tolerancia cero' de los delitos administrativos, el fraude comercial, la contaminación ilegal y las infracciones contra la salud y la seguridad? En realidad, sería más exacto describir las formas de actividad policial realizadas en nombre de la "tolerancia cero" como estrategias de "intolerancia selectiva". (Crawford en Wacquant 2004:17).

Ello es coincidente con lo observado y relevado a lo largo de la investigación en donde la mayoría de las mujeres presas han cometido delitos no violentos. Según datos oficiales, entre 2002 y el primer semestre del 2011 se duplicó el número de mujeres alojadas en las cárceles bonaerenses, pasando de 557 a 1113 . Este aumento sostenido de la población carcelaria femenina constituye un proceso global, que en América Latina se ha visto incrementado a partir de la legislación en materia de estupefacientes. (Observatorio de Violencia de Género de la Defensoría del Pueblo de la Provincia de Buenos Aires, s.f.)

Esta categoría de "intolerancia selectiva" a la que hice referencia más arriba demuestra, en definitiva, que las prácticas en su momento denominadas minorizantes siguen presentes, a pesar del cambio de paradigma. Los "menores" de ayer objetos de tutela por estar en "peligro moral o material", aquellos "menores abandonados" que llegarán a ser "menores delincuentes" y viceversa constituyen un grupo, un colectivo caracterizado por ser personas "incompletas", “inacabadas" que luchan por la redistribución de la riqueza. Ser niño hoy implica ser titular de los mismos derechos que gozan los "no niños", es decir, los adultos, y que de acuerdo con Beloff, cabe sumarles los derechos específicos que surgen de su condición de persona en crecimiento, esto es, ni incompleta ni incapaz. Pero también, como parte de la categoría socialmente construida de infancia en general e infancia pobre en particular, pasan a constituir una

a cualquier persona que pueda ser "razonablemente sospechosa" de un crimen o un delito, muestra que los negros representan la mitad de las 175 mil personas "demoradas y cacheadas" en 1998 y el 63 por ciento de los individuos controlados por la Unidad de Lucha contra los Delitos Callejeros (Street Crime Unit), cuando en realidad son sólo la cuarta parte de la población de la ciudad”. (Wacquant 2004:15) 
comunidad bivalente en tanto están inscritos en las luchas por la redistribución como por las del reconocimiento.

De acuerdo con Fraser puedo sostener que las luchas por la redistribución y el reconocimiento no son cuestiones separadas sin vinculación en donde se aborda una $u$ otra, tanto los reclamos por la redistribución como por el reconocimiento deben afrontarse de manera integral y conjunta.

\subsection{Sumario}

Conforme a lo desarrollado se observa la tensión que existe entre las legislaciones vigentes (los discursos) y la aplicación de dicha normativa (las prácticas). Dicha tensión entre los discursos y prácticas ante un cambio de paradigma receptado en la legislación argentina sobre la niñez fue el eje del presente capítulo. El análisis del contexto en que se promulgó primero la ley de patronato y luego la ley de "protección integral" y la lectura de las infancias a través del marco conceptual de colectividades bivalentes fue fundamental para comprender que los modos de actuar sobre la infancia pobre ante un cambio de paradigma parece sólo pura retórica. Recordando lo expuesto por Diker "el hecho de que el discurso de los derechos haya ganado espacio y que la utilización del término "menor" esté en retroceso no significa que las miradas y las prácticas minorizantes hayan desaparecido." (Diker, 2009:41) El lenguaje del derecho ha servido para reivindicar algunos derechos de las colectividades bivalentes, sin embargo coincido con Birgin (2000) en el sentido que si ese lenguaje oculta las diferencias entre reivindicación de un derecho y la posibilidad de ejercerlo resulta ser en definitiva un engaño. 


\section{CAPÍTULO 3}

\section{REPRESENTACIONES SOCIALES SOBRE EL INTERÉS SUPERIOR DEL NIÑO/A.}

En este capítulo describo los significados dados al interés superior del niño/a (ISN) por los diferentes actores de esta unidad de análisis, es decir la Unidad 33 de La Plata. Para ello, identifiqué los modos en que los mismos significan el rol materno y el ejercicio de la maternidad en el contexto de encierro, así como, los diferentes modos de dar sentido a la construcción de subjetividades en base a las representaciones sobre la crianza de los niños y niñas en dicho contexto.

\subsection{El interés superior del niño en un contexto carcelario}

La Convención Internacional de Derechos del Niño se estructura en cuatro principios que guían la interpretación de la misma: el de no discriminación (art.2), el de efectividad (art.4), de autonomía y participación (arts.5 y 12) y de protección, conocido también como "el principio del interés superior del niño/a" (art 3). (Cillero Bruñol, 1999). Sin embargo, los debates surgidos por la incorporación de uno de sus principios, esto es el interés superior del niño, sin duda lo convirtieron en el slogan más escuchado.

El ISN se encuentra regulado en el art. 3.1 de la CDN. El mismo dispone que "En todas las medidas concernientes a los niños que tomen las instituciones públicas o privadas de bienestar social, los tribunales, las autoridades administrativas o los órganos legislativos, una consideración primordial a que se atenderá será el interés superior del niño."

Esta incorporación a la CDN despertó una amplia discusión doctrinaria pues, mientras para algunos la incorporación de una máxima tan amplia era dejar la puerta abierta para continuar con la doctrina de la situación irregular que se pretendía combatir, para otros, resultaba ser un derecho para hacer posible el ejercicio de otros derechos regulados en la Convención resultando, de ese modo, una aplicación obligatoria para los operadores encargados de aplicar dicho principio.

Es interesante resaltar lo expuesto por Fernández Blanco con respecto a lo generado por el ISN cuando refiere a que: 
"Resulta destacable cómo un principio interpretativo de derechos humanos, como es el del interés superior del niño, ha podido generar debates de un tenor tan profundo. Desde la calificación de "Caballo de Troya de la Convención de los Derechos del Niño" hasta la defensa encumbrada de este principio como una de las columnas vertebrales de la CDN, pasando por posturas que intentan redefinir el principio a la luz de toda la estructura de la Convención. Lo cierto es que, sea como sea entendido, debemos convivir con este principio cual si se tratara de una virtud o de una enfermedad crónica. Y las leyes continúan recogiéndolo como pauta interpretativa, con lo cual su presencia en el ámbito del derecho de los niños, nos guste o no, continúa ocupando un lugar trascendente.” (Fernández Blanco, s.f:17)

Así por ejemplo, Freedman (2005) sostuvo que con la Convención parecía haber llegado a su fin la doctrina de la situación irregular para dar lugar a la doctrina de la protección integral. Sin embargo, con la incorporación del "interés superior del niño" podría ponerse en riesgo la efectividad del modelo de protección integral de los derechos de los niños y fortalecer las prácticas tutelares.

Otros autores le dan un sentido diferente. Por ejemplo Cillero Bruñol (1999) sostiene que el ISN, como los otros principios que establece la CDN, son principios jurídicos garantistas de aplicación obligatoria para las autoridades.

Durante el trabajo de campo, observé que en general el ISN fue representado como una categoría ambigua. En ese sentido, una empleada de la Procuración de la Suprema Corte de la Pcia. de Buenos Aires decía:

"En la Unidad 33 no se cumple el Interés Superior del Niño, nadie [1o cumple]. Ni jueces, ni defensores, ni servicio. Son palabras lindas nada más”; “[...] cada quien le da una interpretación diferente. En pos de eso meto preso gente, lo saco"

Un profesional de la salud de la misma unidad penitenciaria sostenía:

"Yo a veces cuando me enojo digo, la verdad que el interés superior del niño está escrito y pasa desapercibido".

Estos significados dados al ISN están reflejando de algún modo lo que decía Freedman (2005), en el sentido de que parecería que la prácticas tutelares no habrían 
quedado atrás. Recordemos que estas prácticas, como fue desarrollado en el capítulo 2 , posibilitaban decisiones discrecionales por parte de los organismos del Estado, decisiones que en este caso se encuentran reflejadas en lo que decía la empelada de la procuración "en pos de eso [del ISN] meto preso gente, lo saco”.

El art. 4 de la ley de la Provincia de Buenos Aires de promoción y protección integral de los derechos del niño nro. 13.298 (y sus modificatorias), describe que se entenderá por ISN y prevé que ante un conflicto de intereses debe primar el de los niños/as.

Así el art. 4 dispone:

"Se entiende por interés superior del niño la máxima satisfacción integral y simultánea de sus derechos en un marco de libertad, respeto y dignidad, para lograr el desenvolvimiento de sus potencialidades, y el despliegue integral y armónico de su personalidad. Para determinar el interés superior del niño, en una situación concreta, se debe apreciar: a) La condición especifica de los niños como sujetos de derecho. b) La opinión de los niños de acuerdo a su desarrollo psicofísico. c) La necesidad de equilibrio entre los derechos y garantías de los niños, y sus deberes. d) La necesidad de equilibrio entre los derechos y garantías de los niños, y las exigencias de una sociedad justa y democrática. En aplicación del principio del interés superior del niño, cuando exista conflicto entre los derechos e intereses de todos los niños, frente a otros derechos e intereses igualmente legítimos, prevalecerán los primeros.”

La aplicación en la práctica de este artículo no pareciera ser tan fácil. Ello se evidenció en los diferentes significados que cada entrevistado le asigna tanto a la definición del ISN como a la designación de qué derechos estarían contrapuestos para luego poder plantear una solución adecuada al problema.

Sin embargo, de diversas entrevistas se desprenden conflictos de intereses en donde algunos actores contraponen derechos entre los propios niños/as, otros manifiestan que colisionan los intereses de las madres con los de sus hijos/as y de una sola entrevista surge la contraposición entre derechos de los niños/as y el interés de la sociedad (representado por el Estado).

Uno de los pediatras de la Unidad decía: 
"Hay dos cosas: [el niño/a] tiene derecho a estar con la madre y le estoy sacando la libertad y lo estoy criando dentro de una cárcel que no está pensada para mujeres y tampoco está pensada para niños. Entonces ahí son dos cosas que se contraponen, entonces yo creo en estos casos siempre en ir en el caso a caso, ver la posibilidad de cada familia, donde esta parada."

Una integrante del CA, al preguntarle si podía decirme que entendía por ISN manifestó:

“Interés no es uno solo, son varios, y yo no creo que acá haya intereses o derechos vulnerados. Lo que pasa que acá el tema es cual prima ¿cual primaria? ¿el derecho a relacionarse con su madre? ¿el vinculo madre-hijo o a estar en libertad? ¡Qué sé yo! Los dos son importantes, no se cual es más importante [...], si bien no está preso se cría en un lugar que no es el más apropiado, pero también pienso que tiene derecho a estar con su mamá, entonces medio contradictorio desde algún lugar, las dos cosas, por eso te digo ¿qué primás? ¿Qué derecho estas primando como derecho del niño? ¿Derecho a ser libre? Y sí, es libre, porque no está preso pero tampoco puede decir abro la puerta y me voy a diagonal 80, pero por otro lado tengo que estar con mi mamá."

La directora de la Unidad al ser preguntada sobre los significados del ISN dijo:

"Es que sus derechos prevalezcan ante todo lo que los adultos podamos anteponer, porque pasa mucho eso, siempre por ahi se prioriza lo que el adulto necesita y no, es el niño porque el ISN apunta a que la persona pueda formarse en toda su plenitud, si el niño desde chiquito han sido vulnerados sus derechos seguramente su formación no va a ser la adecuada. Entonces después justamente es donde tenemos un montón de gente acá adentro y me parece que la gente que esta acá adentro es una, en muchos casos, en la mayoría, es una parte de lo que le paso cuando eran chicos."

Tanto el pediatra, la integrante del CA y la directora de la Unidad quedan atrapados en la mirada dicotómica entre el estar con la madre aunque dentro de la cárcel o estar sin ella pero fuera del ámbito carcelario. Si bien la directora también es "presa" de esta mirada, agrega su representación sobre los "niños/as escudos", mirada que 
desarrollaré en el apartado "El ejercicio de la maternidad en contexto. La construcción de buenas y malas madres." Aquí, la directora hace referencia a los supuestos beneficios que podrían obtener las mujeres al tener a sus hijos dentro de la Unidad, poniendo en contraposición derechos de los niños/as versus derechos de las madres. A su vez, desliza el supuesto que no deja de ser taxativo, cuando sostiene que los niños/as que crecen en la Unidad van a volver a la misma, en un futuro, pero como "delincuentes".

Al ser preguntada respecto a si existía colisión de intereses agregó:

"Siempre va a prevalecer para nosotros el interés superior del niño, nosotros vemos si un nene está limpio, peinando, uno ve porque estamos vigilando, si es bien tratado, entonces siempre convocamos a cambiar la actitud, lo mismo que para el egreso, prevalece el interés superior del niño, incluso hubo un caso que di intervención al juzgado de familia porque la interna era violenta peligrosa para sí y para terceros y el juzgado ordeno a niñez que lo venga a buscar. No se vulneran otros derechos, los derechos no se contraponen me parece, pero en el caso de las madres si, si prevalece la criatura, no podemos permitir como funcionarios públicos que le pasen cosas a los niños que son indefensos"

La directora reduce el concepto del ISN al "buen" o "mal" trato que pueda darle la madre al niño/a y visualiza sólo la contraposición de derechos entre la madre y el hijo/a. Como funcionaria pública la entrevistada se posiciona desde un lugar de espectadora de las obligaciones que tiene el Estado, al que ella representa, de garantizar todos los derechos de los niños/as enumerados en la CDN.

Sin embargo, es posible plantear el problema del ISN desde otro lugar, no por eso, menos problemático. En ese sentido, una funcionaria de la Procuración manifestó "No existe, no es real que se pueda plantear el ISN en la cárcel, si está en la cárcel [el niño/a] no hay interés superior del niño y tampoco hay ISN afuera, sin la mamá. Entre el derecho del chico y la seguridad de que la madre este en la cárcel, no hay duda que prima el derecho del niño."

Aparece aquí planteada la colisión de intereses entre los de la madre y el hijo/a por un lado, contra el interés del Estado por el otro. Así es como también lo 
entiende Rivera Beiras (2005) quien sostiene, citando a Naredo, que en la búsqueda de soluciones al encarcelamiento de madres con hijos/as se ha partido de una base falsa: la colisión de derechos entre los de la madre y los del hijo/a. Si partimos de esta base falsa caeremos en una aporía, esto es "una dificultad de orden lógico que no tiene una resolución en los términos en que el problema fue planteado. Se trata de una cuestión sin solución, sin síntesis posible, a menos que el problema sea reformulado" (Rifiotis en Rifiotis y Castelnuovo, 2011:17)

Nos encontramos frente a una colisión de intereses no reductible a ser pensada entre madre/niño/a - niño/a/madre, sino frente a una colisión de derechos entre el niño/a frente al interés del Estado en la persecución penal o cumplimiento de una pena.

Sin embargo, la mirada centrada en el binomio madre/hijo-a vislumbra la naturalización del rol materno y por ello, en los apartados siguientes identifico los modos en que los roles asignados culturalmente a las mujeres en el ejercicio de la maternidad y crianza siguen siendo hoy naturalizados tanto desde la normativa como desde las prácticas cotidianas.

\subsection{La naturalización del rol materno en la norma}

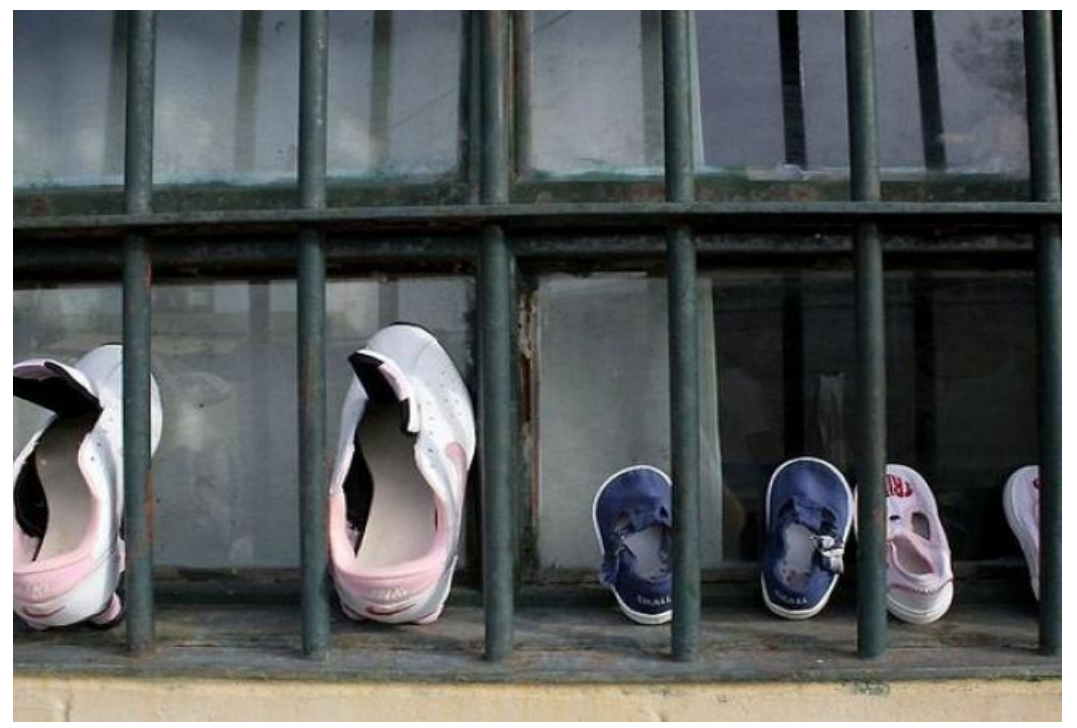

La noción de infancia, como categoría relacional, presupone la existencia de adultos. Por ello las políticas de intervención estatal relacionadas con las infancias no se pueden disgregar de las políticas y regulaciones sobre las relaciones familiares, las 
formas de crianza y los valores asociados con la paternidad y, fundamentalmente, con la maternidad. En ese sentido, propongo, aquí, pensar críticamente los modos en que se construye el rol materno "entre rejas" no solo desde las prácticas, sino también, desde la normativa que (re)produce los discursos moralizantes que naturalizan del "amor materno".

Conforme ello Villalta sostiene que:

"el término complementario y no contradictorio que les corresponde [a los hijos] es el de padres. Por ello, la gestión de la infancia, esto es, los intentos de transformarla y reencauzar sus conductas, también y centralmente involucra a sus familias, a aquellos que "naturalmente" son vistos como sus responsables, y por ello se orientan de, una forma u otra, a configurar un "orden familiar" para esos niños." (Villalta, 2013:259)

¿A qué familias hacemos referencia cuando decimos que las mismas están involucradas en la gestión de las infancias?

A fines del S. XVIII, con el advenimiento de la Revolución industrial, fue necesario imponer un orden social que encontró en la construcción de la familia nuclear la manera de establecer dicho orden. Esta institución occidental instala un determinado modo de disposición social que se traduce en la conformación de familias heterosexuales con roles bien definidos: los hombres en la esfera pública de producción y las mujeres en los círculos privados de reproducción, aunque la vida de muchas personas no encajara ni encaje con ese modelo.

\section{En esta línea Fraser relata}

"El orden de género [...] es un legado de la era industrial del capitalismo y refleja el mundo social en el que tuvo origen. Aquel mundo estaba centrado en el ideal del salario familiar. Se suponía que las personas estaban organizadas en familias nucleares heterosexuales encabezadas por un hombre, cuya principal fuente de ingreso era el salario del hombre en el mercado de trabajo. El hombre cabeza de familia recibía un salario familiar, esto es, un salario suficiente para mantener a los hijos y a una esposa- y -madre de tiempo completo, quien se dedicaba al trabajo doméstico de tiempo completo, sin recibir ninguna remuneración." (Fraser, 1997:55/56). 
En la Argentina, durante el S. XIX se fue gestando la idea de la familia nuclear como orden social, pero fue recién a comienzos del S. XX que pasó a ser una "cuestión de Estado" (Nari, 2004). Durante el S. XIX la idea de familia nuclear se instalaba en las elites, sirviendo el matrimonio como forma de mejoras sociales y económicas; sin embargo para las clases populares esta institución no se instalaría hasta principios del S. XX. Ello como consecuencia de las diferentes circunstancias que se vivían en aquella época; en un principio, vinculado a las guerras civiles, comenzaron a visibilizarse los colectivos de las mujeres trabajadoras y niños/as en las calles. Luego, con la gran inmigración, las familias crecieron, se establecieron redes familiares solidarias, conventillos como espacios de residencia en donde se advertían diversas formas de unidades domésticas: familias de tres generaciones, hombres solos, familias con parientes colaterales. Todo ello fue visto como "desordenes" familiares que podían gestar “desordenes” más amplios, morales y sociales. (op. cit.) En palabras de Nari:

"Las diversidades domésticas desbordaban la simplicidad del modelo de familia. Un modelo que se fue construyendo desde el derecho, la medicina, la "economía doméstica" y las prácticas sociales: nuclear, patriarcal, legitimado y legalizado por las leyes, cuyo padre detentaba el poder y era el proveedor material, vertebrado en la relación madre-niño, una madre-ama de la casa” (Nari, 2004:62,63).

¿Por qué las mujeres tenían el mandato "natural” de quedarse en el hogar? Porque la posibilidad de reproducción biológica de las mujeres (concepción, embarazo, parto y lactancia) se relacionó como algo inescindible con las tareas de cuidado y crianza, naturalizándose de ese modo dichas tareas.

En el campo trabajado, a través de las palabras de una entrevistada integrante del Consejo Asistido, pude identificar esa naturalización del rol femenino. En ese sentido la entrevistada decía: "primamos el vínculo, ahí no podes sacar a un nene de dos meses, ¿qué hace en el afuera? ¿Quién lo cría? Por más que lo cuide la abuela con el mayor de los amores. Lo importante que por lo menos 6 meses, mínimo, este con ella".

Retomando el relato de Fraser, en cuanto a la no remuneración del trabajo doméstico, las tareas llevadas a cabo en el espacio público se construyeron como trabajo remunerado mientras que las tareas desarrolladas en el espacio privado no. Este hecho 
generó una serie de consecuencias en muchos aspectos de la vida de las mujeres que no solo se han expresado en la dependencia económica sino también, simbólica; consecuencias que no profundizaré ya que exceden lo pretendido en la presente investigación.

Con todo, el ensayo de Collier, Rosaldo y Yanagisako da cuenta de ello al exponer:

"mucho de lo que da forma a nuestra concepción de La Familia es su oposición simbólica al trabajo y los negocios, en otras palabras, a las relaciones de mercado del capitalismo. Después de todo es en el mercado donde vendemos nuestro trabajo y negociamos relaciones contractuales de trabajo y nos asociamos en relaciones competitivas y temporarias" (Collier, Rosaldo, Yanagisako, 1997:6)

Esta construcción social de las familias y las mujeres no es ajena a nuestra normativa, y en el caso específico de los dispositivos jurídicos que nos ocupan en este trabajo, la ley nacional de ejecución penal 24.660 (y sus modificatorias) en su artículo 195 establece que las "mujeres madres" podrán "retener" consigo a sus hijos menores de cuatro años.

Quisiera detenerme por un instante en la acción de "retener" para luego continuar con la línea argumental del capítulo.

"Retener", en el diccionario de la Real Academia Española, tiene varias acepciones entre ellas: Impedir que algo salga, se mueva, se elimine o desaparezca; interrumpir o dificultar el curso normal de algo; imponer prisión preventiva, arrestar.

Las dos primeras acepciones hacen referencia al accionar sobre "algo" y no sobre "alguien", en consecuencia no serían las adecuadas para la redacción del artículo, el cual hace referencia a los hijos e hijas menores de cuatro años de las mujeres presas, máxime cuando al momento del dictado de la ley, la CDN, ya se encontraba incorporada a nuestra Constitución Nacional. Recordemos que la CDN adopta la doctrina de la protección integral donde los niños y niñas no son “objetos” sino sujetos de derecho.

La tercera acepción se refiere a imponer prisión preventiva y/o arrestar. Quizá no fue la intención de los legisladores decir que las madres podían "privar de 
libertad" o "arrestar" a sus hijos e hijas, aunque en la práctica ello está muy cerca de ser así. Más adelante veremos como las mujeres lo sienten de ese modo.

Retomando aquí la discusión relativa a la ley nacional de ejecución penal 24.660, que establece la posibilidad de las mujeres a "decidir" permanecer con sus hijos/as en la cárcel, nos encontramos frente a una ley que intenta "normalizar" relaciones familiares $\mathrm{y}$, de ese modo, restablecer el orden de género impuesto desde la revolución industrial, orden que acompañará a las mujeres y traspasará las puertas de la cárcel.

En el contexto carcelario descripto en el capítulo 1, he dado cuenta de que la vigilancia no solo recae sobre la detenida por su condición de tal, sino también, en el ejercicio de su maternidad. Eso me permite traerlo nuevamente al análisis para describir algunos modos "sutiles" de discriminación, casi imperceptibles que recaen no solo en las mujeres, sino también, en sus hijos/as.

\subsection{El ejercicio de la maternidad en contexto. La construcción de buenas y malas madres}

La maternidad, en tanto constructo social, no siempre estuvo asociada a la crianza y educación como aparece en el sentido común hegemónico en general y en algún sentido común académico, en particular. Badinter (1981) nos hace recordar a las mujeres francesas quienes, durante el S. XVIII, luego de parir a sus hijos e hijas, delegaron su crianza y educación en nodrizas. Estas mujeres, en aquella etapa, intentaron definirse como seres autónomos y para ello tuvieron que alejarse de las tareas que las definían como madres y esposas en tanto la maternidad no se valorizaba positivamente ni les representaba ninguna gloria.

En efecto, Badinter sostiene:

"Comprendieron que para tener derecho a alguna consideración debian seguir un camino que no fuera el de la maternidad, que no les aseguraba el menor reconocimiento. Pero para poder aunque más no fuera pensar en ello, debían estar libres de las cargas propias de la condición femenina común: contingencias materiales, autoridad del marido y aislamiento cultural." (Badinter, 1981:79) 
Si bien aquí planteo una mirada crítica a fin de reflexionar sobre el ejercicio de la maternidad, la realidad de las mujeres que se encuentran detenidas no es ajena a los significados otorgados a la maternidad por los actores de la Unidad en este espacio y tiempo.

En ese sentido, es interesante la reflexión que realiza Grassi (1992) sobre el instinto materno cuando expresa:

"Hay profundas transformaciones al nivel del mundo de la vida, pero hay cuestiones que mantienen casi intacta su carga simbólica. Una de ellas es la maternidad como instinto, vigente en las representaciones sociales acerca de los géneros. Y renovada en corrientes internas de campos científicos constituidos en relación con la maternidad y con las relaciones parentales; o en algunos discursos del propio movimiento de mujeres, que proponen una "vuelta a la naturaleza" en materia de procreación y crianza" (Grassi, 1992: 120/121)

En coincidencia con lo sostenido por Grassi, el discurso hegemónico en Argentina, continúa mostrando que las actividades de crianza y educación se encuentran asociadas a la "naturaleza femenina" y acompañadas de los sentimientos de "amor" y de "instinto materno", lo que conlleva a la realización de discursos moralizantes respecto de las formas en que se ejerce la maternidad, discursos que no escapan a las representaciones de las detenidas.

En palabras de una madre detenida en la Unidad

"El ser madre dentro de 4 paredes no es fácil [...] Y buscarle la vuelta y hacer que un familiar lo saque [a mi hijo] del establecimiento para un mejor bien estar, también los daña porque tienen todo, pero no lo mas importante, yo que soy su mama” (Marianela) (el subrayado me pertenece).

De esta entrevista surgen dos cuestiones. Por un lado, aparece ese discurso hegemónico sobre la presencia de la madre como fundamental. Y por el otro, la tensión que se desprende respecto a que la cárcel no es el lugar más adecuado para criar a un niño/a, sin embargo se naturaliza que los niños/as tienen que estar con "LA MADRE". Se ponen en tensión derechos de los propios niños/as: libertad o crecer en el seno de una 
familia; familia que, en el contexto que se corresponde con nuestro referente, se reduce a la madre.

Esta complejidad de sentidos donde prima el discurso hegemónico sobre la maternidad y la tensión que genera el hecho de que algunos niños y niñas se encuentren en la cárcel, se evidenció también en discursos de otras mujeres detenidas. Ello tendría su fundamento, en concordancia con lo que sostiene Naredo (2012), en el hecho de depositar la culpa sobre las mujeres por su situación de presa y no poder ejercer el rol asignado socialmente de criar y educar. Así lo relataron mujeres alojadas en el pabellón de "madres":

“me gustaría que si está a su alcance me de otra oportunidad para volver a casa con ellos [sus hijos] a través de una prisión domiciliaria por el solo motivo de cuidar a mis hijos, ellos no tienen porqué estar pasando esto por mi culpa, para mi esa es mi gran condena, no tenerlos, no verlos felices ni juntos con una mamá, que está viva pero la situación no permite que me acerque ni que pueda cumplir el rol de mamá." (Mariela, alojada en el pabellón 10 de la Unidad 33).

"La entro [a mi hija] al pabellón y se choca con las paredes o intenta llamar a la encargada para escaparse de mí. Estas son pequeñas cositas que hacen que me sienta tan culpable de que este acá, no tengo la posibilidad que se vaya mucho de paseo." (Natalia, alojada en el pabellón 10 de la Unidad 33).

El sentido dado por las mujeres a la "privación de libertad" de sus hijos/as coincide con la tercera acepción de "retener" a la que hacía referencia en párrafos anteriores. Estas mujeres que, por innumerables y disímiles motivos, "retienen" a sus hijos/as consigo se sienten responsables o "culpables" (al decir de Naredo) por ejercer el derecho de decidir convivir con sus hijos/as en el del encierro.

Tal como vengo desarrollando, la idea "sagrada" de la maternidad comprendida a través del binomio madre-hijo/a, se encuentra fuertemente arraigada en las mujeres detenidas tanto como en el personal del servicio penitenciario y profesional de la salud vinculados a la institución.

En palabras de algunas entrevistadas: 
"Ser madre en el encierro es tremendo, tremendo, es tremendo, porque sabes que tus hijas, yo que había dejado a mis dos hijas, de cinco y tres años, si bien estaban con mi mamá, y sabía que las iba a criar bien y las iba a educar como nos educó a nosotros, sabes que van creciendo sin vos, que crecen, que llega el cumpleaños, que llegan las fiestas, y que vos no estás, que están enfermas, que tienen fiebre y vos no estás, que se hacen señoritas, que van al colegio, que siguieron estudiando. [...] entonces es la angustia y es una mezcla de un montón de cosas, de saber que te necesitan, de que surgen cosas, que si bien están con los abuelos pero ellas necesitaban a la mamá." (Gabriela, madre detenida en la Unidad 33).

"La maternidad [...] se supone que tiene que ser vista [...] como un estado especial de las mujeres en un proceso de gestación y después en un proceso especial de contención” (Funcionaria de la Procuración General de la Unidad Penitenciaria 33).

De las dos entrevistas surge claramente esa extensión de lo natural del estado biológico de gestación a ese estado especial de contención que es cultural, naturalizando el rol materno tal como referí en el acápite: "La naturalización del rol materno en la norma." Rol que aparece también aquí, representado en la frase "la maternidad [...] se supone que tiene que ser vista", dando cuenta del sentido común hegemónico de la madre como responsable primaria de la crianza y educación de los niños y niñas.

En nuestro país, Grassi ubica la construcción del binomio madre-hijo/a a fines del S. XIX y principios del S. XX, durante los cuales transcurrió el proceso de consolidación y expansión del Estado nacional. De este modo, la autora expresa:

"Las campañas de salud fueron un vector fundamental, junto a los hábitos de higiene, se enseñaron a las mujeres la economía doméstica, el orden en el hogar y los hábitos del ahorro. Lo que comenzó a llamarse el "binomio madre-hijo" (que expresaba simbólicamente una pretendida unidad esencial) fue, además la expresión pragmática ante la necesidad de encontrar vías eficientes de hacer frente a problemáticas del momento: el orden, la moral y la salud. La promoción de la lactancia materna, la consagración de las madres a la atención de los niños y del hogar, el cuidado de la higiene (como una dimensión del amor materno, del que venía a 
depender la salud pública) eran ejes centrales de las acciones políticas en materia de salud”. (Grassi, 1996:106)

Ese sentido común hegemónico genera, entre otros, el sentido de que la mujer en ejercicio de la maternidad deba ser casi una heroína, buscándose en general causas exculpatorias, como la "carencia" o la "cultura" si no resulta ser de ese modo. En el campo, ello se cristalizó en la idea de la maternidad como "sagrada", la madre vista como protectora, dulce, contenedora, sacrificada, sensible, abnegada y dócil: la buena madre.

Algunas entrevistas dieron cuenta de ello, como por ejemplo, la de un pediatra de la Unidad quien sobre el ejercicio de la maternidad en el encierro decía:

"poniéndome en el lugar de la madre, lo angustioso que es perder la libertad [...] la verdad que ellas se aferran mucho al hijo que tienen ahi adentro, como que lo cuidan y lo sobreprotegen bastante, pero por esta situación, por su propia historia, la verdad que las madres se preocupan [...]; en un porcentaje elevadísimo las madres se preocupan muchísimo por sus hijos, y son muy buenas madres, y los tienen ahí adentro porque saben que ahí adentro están mejor que si estuviesen en otro lado, con su familia incluso en algunos casos, así que el ejercicio de la maternidad ahí adentro, me parece que es bastante duro y tiene sus individualidades, tiene su cosa especial de estar ahí adentro. Entonces me parece que la maternidad ahí adentro es difícil." (Pediatra de la Unidad Penitenciaria 33) (El destacado me pertenece).

La representación que el pediatra tiene sobre las madres en la Unidad es la que se corresponde con las buenas madres, esa es su verdad: se preocupan por sus hijos, los sobreprotegen, tienen a sus hijos e hijas allí con ellas porque saben que allí están mejor que afuera. Lo especial de "estar allí" adentro, en una institución cerrada, con las características descriptas en capítulo 1, convierte a las madres en mujeres redentoras.

Pero a su vez se encuentra presente otro discurso, el de las anti-madres, las carenciadas, delincuentes, rebeldes, insensibles, egoístas, las malas madres. Conforme este discurso Naredo sostiene:

"la mujer que delinque obtiene un mayor reproche social que el hombre, pues no ha sabido comportarse conforme al rol que le viene asignado por la sociedad, 
por un lado sumisa, pasiva, obediente y, por otro, representante del orden familiar, mediadora de los conflictos ajenos, etc ... El inconsciente colectivo convierte a la mujer presa en una <antimujer>, en una madre desnaturalizada, de este modo, tiene que soportar <una doble estigmatización: primero como delincuente pero además como mujer delincuente $>$ " (Naredo, 2012: 271).

Así, algunos actores del referente empírico ponen por sobre el hecho de que las mujeres son madres, el hecho de que son mujeres presas, y por ello, ante algunos pedidos realizados por este conjunto particular de mujeres, identifican dichos pedidos con la noción de la utilización del niño/a para beneficio propio.

A pesar entonces de la sacralización de la maternidad, de estos últimos relatos surge el discurso del "niño/a escudo" (niño/a cosa) en donde algunas mujeres se aprovecharían o utilizarían a sus hijos e hijas al ingresarlos al penal en función de conseguir algunos "beneficios". En ese sentido la jefa de vigilancia y tratamiento decía "Hay mamas que también traen a sus hijos acá por el hecho de que tienen ciertos beneficios".

La directora del penal, al ser preguntada con relación a si las mujeres presas tenían alguna mejora por la situación particular de estar con sus hijos/as dijo “¿Que se aprovechan porque están con los hijos? si, es algo que se nota, todos coinciden y siempre quieren más en nombre de que son madres".

Vemos que ese "todos" está representando ese inconsciente colectivo al que hacía referencia Naredo (2012).

Una empleada de la procuración decía "El discurso existe que los utilizan para lograr algún beneficio, tanto del servicio penitenciario como de algunas madres [...] en realidad no hay ningún beneficio extra, más que un pedazo más de carne por tener un pibe ahi adentro, que es una carne que no se puede comer ni acá ni en ningún lado".

Sin embargo, en la práctica observé otra realidad, algunas mujeres sobreprotegen a su hijos/as, otras no, algunas mujeres tienen a sus niños/as allí porque consideran que están mejor que afuera y otras no, otras mujeres tienen allí a sus niños porque así lo quieren y así lo deciden y otras porque no les queda otra alternativa. ¿Esto 
las convierte en buenas o malas madres? Mi experiencia en el campo me permite sostener que las diferentes formas de criar y evaluar el qué hacer en una determinada situación no las convierte ni en buenas ni en malas madres, lejos de ello, representan modos diferenciales de llevar adelante el ejercicio de la maternidad en un contexto particular que, en nuestro caso, es la cárcel.

Durante las entrevistas, las respuestas sobre el ejercicio de la maternidad en el contexto de la cárcel se basaron en valoraciones morales, esto es en términos de los significados otorgados a ser "buenas" o "malas" madres y no, en los modos posibles de crianza o en las dificultades que encuentran las mujeres presas para ejercer dicho rol. A su vez, los sentidos inscriptos en el ejercicio de la maternidad se subsumen al hecho de ser madres biológicas.

En ese sentido la jefa de asistencia y tratamiento de la Unidad manifestaba que:

"Hay excelentes madres acá, internas excelentes madres, es lo mismo que afuera, tenés de todo, yo creo que también pasa por la cultura que traen, la mayoría de la gente es gente con bajos recursos la que está detenida, [...] la relación de los pabellones de madres, entre ellas inclusive, es muy distinta al de la población común, las mamas se cuidan y se protegen entre ellas, se acompañan mas, no tienen el cierre de la celda unicelular como tienen en población. Ellas tienen la placita para sus hijos".

Como se observa, la entrevistada comienza con un juicio de valor para luego fundamentar algunas prácticas ("se cuidan, se protegen entre ellas") asociando dichas prácticas a "la cultura". Es interesante detenerse apenas en el significado otorgado a la cultura; en palabras de la entrevistada "la cultura que traen". Como se puede observar, los sentidos otorgados al concepto se reducen a su acepción del sentido común que la concibe como "una cosa", capacidad o hábito adquirido a través del aprendizaje y que son inmanentes a determinados grupos o facciones de grupo. Cultura se homologa así a un modo de vida clasificado a priori a través de una lista de rasgos. Este modo esencialista es el que posibilita la mirada paternalista y condescendiente sobre la crianza en situaciones de encierro carcelario. 
He señalado que algunas de las detenidas se protegen entre ellas y otras no, y he expuesto en el capítulo 1 la relevancia de los liderazgos que se generan al interior del pabellón y dentro de la institución. De hecho, la placita a la que hace referencia la entrevistada, es el lugar de encuentro para "arreglar" sus diferencias ${ }^{25}$.

Respecto a los juicios de valor es interesante lo relatado por Villalta quien sostiene que:

"La tarea de protección de la infancia parece remitir en primer término y casi indefectiblemente a la evaluación de su familia, de sus madres, padres, abuelos u otros parientes, es decir de los adultos que son considerados como responsables de los niños o de los adultos que eventualmente pueden llegar a serlo (Vianna, 2010). Por lo tanto, la familia será juzgada, explícita o implícitamente, en términos de "buena” o "mala”, "no continente", "negligente”, "tramposa” o "aprovechadora” (Villalta y Llobet, 2012) entre otros rótulos que aun hoy se pueden escuchar o bien leer en los informes profesionales - principalmente sociales y psicológicos-que son elaborados en este campo institucional." (Villalta ,2013:260). ${ }^{26}$

Siguiendo con los sentidos otorgados a la maternidad en contextos de encierro carcelario, la directora del jardín maternal "Las palomitas" decía:

"Yo no lo dejaría [al niño/a] estar en la Unidad con la madre. Yo no los tendría ahi. Nosotras que vamos diariamente, vemos poca higiene, maltrato de las madres, las madres los usan de escudo, ellas lo van a negar porque son las mejores madres del mundo, ¿no? Pero por algo están ahí. Es muy feo, si tenés la posibilidad de ir a verlo, anda y velo [...] creo que vas a opinar lo mismo, yo prefiero que estén como digo yo, en cualquier villa y no ahí, porque puede ser muy humilde la familia y por ahí no se lo quiere llevar, pero siempre es mejor en la familia fuera del encierro ese, y como se vive ahi y las cosas que ven los nenes. Para mi es mejor que estén libres." (Directora del jardín maternal)

\footnotetext{
25 "Diferencias" en el sentido de peleas que incluyen la violencia física.

${ }^{26} \mathrm{Si}$ bien Villalta refiere a los que fueran los juzgados de menores y a organismos administrativos de protección de derechos de los niños/as, su reflexión suma a la discusión que ofrezco en este acápite.
} 
La entrevistada se posiciona desde un lugar paternalista realizando afirmaciones generalizadas a partir de una mirada negativa sobre las mujeres detenidas, centrada en su representación de que existen mujeres mal intencionadas: "Yo no dejaría”, "yo prefiero", "yo no los tendría”, "para mí es mejor”. Sin embargo, la entrevistada no puede preguntarse por las posibilidades y herramientas que posee cada una de las mujeres para poder ejercer la maternidad dentro de un contexto carcelario. Frases generalizadas como "los usan de escudo", "ellas te lo van a negar porque son las mejores madres del mundo, ¿no?”, “pero por algo están ahi”, evidencian la gran carga moral que condensa los sentidos otorgados a la maternidad.

También se revela aquí la representación de la que hablara Goffman (1992) sobre los diferentes grupos y como, el personal de las instituciones totales se representa al grupo de internos/as a través de estereotipos clasificándolos "crueles" e "indignos de confianza". A su vez, ese "por algo están ahi" me recuerda frases escuchadas en la vida cotidiana como: "y bueno si no están tan bien ahí adentro, hay que gente que afuera está peor”. Estos sentidos llevan a preguntarme por el principio de inocencia cuando, como en este caso, la mayoría de las mujeres se encuentran procesadas. Estas representaciones son coincidentes con parte del discurso oficial penitenciario que no ve o hace distingos entre procesadas y condenadas.

Sostengo que la maternidad no se encuentra sujeta a un hecho natural sino que es el resultado de un proceso histórico social. Como construcción social, en este apartado se puso en evidencia que aún en los contextos más difíciles como el contexto carcelario, las mujeres deben cumplir con el mandato cultural impuesto. Categorías como la de "retener" ponen sobre el tapete que más allá de las valoraciones positivas o negativas sobre "la madre" en términos de "buena" o "mala", "virtuosa" u "ociosa", la única que tiene la posibilidad de "decidir" sobre el destino de los hijos e hijas sigue siendo ella, volviendo a la idea de la normalización de las relaciones familiares.

\subsection{Los discursos de verdad. El saber médico}

Una perspectiva antropológica sobre la crianza nos ayudará a comprender las diferentes prácticas relacionadas con la salud infantil y los significados dados a la crianza de los niños y niñas en esta unidad de análisis. 
Según los significados y representaciones que tengamos sobre la niñez serán los sentidos otorgados a la crianza del niño/a y de su cuerpo. A su vez, dependiendo de las dimensiones históricas, geográficas y políticas en un contexto determinado, la crianza encontrará diversos modos de ser entendida.

En ese sentido y en cuanto al concepto de crianza como un proceso sociocultural históricamente situado, Colangelo refiere que:

“cada una de las acciones puestas en práctica o propuestas para criar a un niño lleva implícita una serie de representaciones y clasificaciones sobre el cuerpo infantil que, a su vez, remiten a nociones más amplias acerca de la infancia, el sujeto, el ciclo de vida, la familia y los vínculos sociales." (Colangelo, 2014:2).

Una de las representaciones acerca del cuerpo infantil, la infancia y la familia se desprende de lo dicho por un médico pediatra de la Unidad quien refirió:

"yo creo que el chico en la primera etapa, sobre todo en la parte donde se desarrolla y donde crece que son los dos primeros años de vida es una etapa muy interesante [para] que este con la madre, con una madre, cuando vos le sacas la madre a ese chico [...] el chico va a tener un retraso madurativo seguro, porque no está la madre, la presencia de la madre es fundamental." (El destacado me pertenece).

Aquí se deposita toda la responsabilidad de cuidado y crianza en la madre desconociendo que la maternidad es una construcción social y que, por lo tanto, no se reduce a lo biológico. Además liga o entrelaza el "retraso madurativo seguro" a la ausencia de la madre sin contextualizar ninguna otra circunstancia más que una ausencia determinada por lo biológico. Y en ese sentido me pregunto ¿Todos los niños y niñas que por alguna circunstancia vivencian la ausencia de su madre [biológica] sufren o han sufrido retraso madurativo? En mi opinión, que la ausencia de la madre, entendida sólo en términos biológicos, sea el origen y consecuencia del retraso madurativo de un niño/a es un reduccionismo a la vez que un razonamiento falaz. He sostenido que las relaciones sociales son construcciones, por lo tanto la (in)madurez de un niño/a deberá ser evaluada en términos de un contexto más amplio que involucre, además de las posibles relaciones parentales otros espacios de sociabilidad, tales como, instituciones escolares, de salud, de esparcimiento y, sobre todo, su propia capacidad de agencia. 
A partir del discurso médico y particularmente con el surgimiento de la pediatría como especialidad, a comienzos del S. XX se establecen parámetros "esperables" en el "crecimiento" y "desarrollo" del niño/a con relación a la alimentación, hábitos de sueño, motricidad, juegos que pasan a formar parte del "sentido común", producto de un discurso especializado cuya capacidad incluye la de operar como censor. Ello quedo en evidencia en cuanto una de las madres relataba:

"mis hijos sufren muchas necesidades materiales que son indispensables para su desarrollo $\boldsymbol{y}$ crecimiento. Se crían en un ambiente donde se dañan psicológicamente, cada vez que el personal penitenciario (encargadas) entra al pabeyón, los chicos se asustan, tienen miedo, el ruido de las botas, de las rejas, cada vez que golpean serrando un candado, eso ase que se sobresalten y les causa miedo, la mala alimentación, no tener una fruta o un yogur "duele”, que no conozcan una "mascota", sea un perro, gato, pajarito, todo eso le daña moralmente porque cuando salen de paseo todo ruido todo animal a ellos les asusta." (Transcripción textual del cuaderno escrito por las madres detenidas en el marco del proyecto de extensión universitaria).

El cuaderno al que me refiero, escrito por las propias madres, surgió uno de los días en el que estábamos trabajando en el marco del proyecto de extensión universitaria. Entre todas, madres y extensionistas, surge a partir de la charla la posibilidad de escribir en un cuaderno lo que les pasaba a cada una de de ellas con relación al ejercicio de la maternidad en el encierro y cómo hacían frente a situaciones que vivían adversas. Esta experiencia, dado que parte del objetivo propuesto era que el cuaderno circulara y que todas leyeran lo expresado por todas, les sirvió para (re)conocerse y reconocer los modos, no necesariamente diversos, de encarar las situaciones vividas en el encierro y encontrar modos solidarios de interacción. No obstante, dado que no se trata de un detalle menor, este cuaderno reflejó también, la forma en que estás "mujeres madres" consideraban el modo socialmente pertinente de ser valoradas por terceros lectores revelando, lo que suponían, estos esperaban escuchar de sus relatos.

En la misma línea, una empleada de la Procuración general, con relación al encierro de los niños/as junto a sus madres decía: 
“dificulta la resocialización de ese niño, socialización en términos de primer aprendizaje; el contexto es nocivo, cualquier persona que uno le pregunta que es la cárcel no va a decir nada lindo nunca, y si lo encontramos dudemos. Entonces a partir de ahi me parece que el lugar inevitablemente va a complicar el desarrollo de esos chicos"

Desarrollo, crecimiento, socialización son categorías que, para la entrevistada, remiten al niño/a no como una persona completa sino como alguien en estado de "naturaleza" que debe incorporar ciertos valores determinados en una sociedad determinada para poder vivir en dicha sociedad: se va "socializando". Así, el niño/a con el paso del tiempo va "creciendo" y va pasando por diferentes etapas cumpliendo con parámetros determinados para cada etapa, es decir se va "desarrollando".

Estos parámetros esperables en todos los niños y niñas de nuestra sociedad actual parecerían no ser alcanzados por los niños/as que se encuentran en la Unidad 33 entendidos como pasivos, inconmovibles, neutros, pacientes, esto es, sin capacidad de agencia. En ese sentido una de las funcionarias de la Procuración General de la Provincia de Buenos Aires relataba:

"A los nenes en las unidades los veo falto de estímulo, básicamente, y con un gran nivel de simbiosis con la madre y con una falta de posibilidad de seguir los caminos que establece la psicología evolutiva, digamos, un nene se complementa con su medio [...] la guardería, el jardincito y si todos estos afueras no complementan su vida, su vida es muy chiquita y por lo pronto no crece, no madura [...] camina más tarde, deja los pañales más tarde, habla más tarde, lo que fue palmario"

Por un lado, desde el discurso hegemónico sobre la niñez encarcelada lo único que necesita el niño/a es a su madre biológica, y por el otro, aparece asomando casi imperceptible otro discurso respecto de la "simbiosis", leída negativamente (no maduran, no se desarrollan) en virtud del vínculo que establece este colectivo particular de niños/as con sus progenitoras. Las categorías "crecimiento" y "desarrollo" establecen modos de crianza basados en el saber médico, categorías sin embargo, que fueron desnaturalizadas por Chris Jenks (1996) y retomadas por Colangelo quien sostiene que: 
"la metáfora del "crecimiento" hace del cambio anatómico que acompaña a la infancia un indicador de una transición social. A su vez, combinando la idea de una temporalidad lineal a lo largo de la cual el niño inevitablemente debe cambiar, el supuesto de que este cambio es un proceso natural, realización de lo que es biológicamente inherente, y la noción de progreso como guía de las transformaciones esperadas, el "desarrollo" se constituye en la metáfora primaria a través de la cual la niñez es explicada y articulada con la noción de futuro (Jenks, 1996). En efecto, crecimiento y desarrollo hacen de la infancia un comienzo y una realización futura, y del niño un ser inacabado, incompleto pero maleable, en proceso de constituirse como un ser humano completo - es decir, como adulto- de manera gradual y progresiva." (Colangelo, 2014:5, 6).

La desnaturalización de estas categorías nos conmina a pensar en que no todas las sociedades establecen los mismos modos de crianza y las mismas formas de representarse a la infancia. Cada sociedad establece pautas o determinados valores para que los individuos ingresen a ellas. Esas pautas y valores (rutinas de alimentación, aseo, vestimenta, educación) conforman los modos de construcción de las personas esperables para dicha sociedad. Las prácticas de crianza en nuestra sociedad están destinadas a incorporar gradualmente habilidades para lograr la autonomía del niño/a. (Colangelo, 2014).

Estas diferentes prácticas como sostiene Colangelo apuntan a:

"un proceso de construcción de la persona concebida en términos de individuo, modelo particular surgido en las sociedades occidentales modernas que se configuran a partir del Renacimiento, en las que el individuo deviene el foco autónomo de sus elecciones y valores, recortándose, a través de la idea del "yo", de su cuerpo, de la colectividad y de la naturaleza." (Colangelo, 2014:6).

A su vez, en una misma sociedad no existe un único modo de criar a los niños/as, sin perjuicio de que haya pautas hegemónicas legitimadas en el discurso científico, en este caso en el saber médico.

Este discurso científico estuvo presente en varias entrevistas, por ejemplo, en el de una funcionaria de la Procuración General de la Provincia de Buenos Aires. La 
funcionaria relataba su experiencia llevada a cabo en la Unidad 33, a propósito del programa de extensión universitaria "Unidad de Atención en Conflictos Juveniles (UACJ)" de la UNLP, esgrimiendo la importancia de ofrecer a las mujeres detenidas charlas referidas a "cómo debía ser el desarrollo de los niños/as conforme sus etapas evolutivas"; esto es, "enseñarles" a ser madres y a criar a sus hijos, en tanto serían un colectivo social inmaduro e ignorante. Así fundamentó su posición:

“¿Qué es la maternidad, la función materna? Es poder contener, sostener, alimentar, fomentar, hacer crecer, madurar, todo este camino, vos a tu hijo, digamos es como si fueras una persona que estas cuidando para que el otro pueda ser, en la medida que vos no sos, no vas a poder contener [...] ni que el otro sea, vas a actuar como hacemos todos ¿Cómo aprendemos todos la mayoría de las cosas? Por imitación. Lo que nosotros veíamos que al nene de un año le daban mamadera y cama, mamadera y cama, alguna en algún momento la mamadera y cama fue la respuesta, y la mamadera y cama es la respuesta institucionalizada. Cuando nosotros empezamos a hablar [...] el nene de cuatro tiene que hacer tal cosa, che jviste que el hijo de la Rubia no lo hace? ¿Viste que el hijo de fulanita no camina? Digamos, es porque esos parámetros que son parámetros científicos nadie se los dio, nadie les dijo, nadie les informó, entonces ¿qué hicieron? se manejaron con los parámetros culturales, ¿está bien que se arrastre y que diga da, da, da, y que no hable? ¡no está bien! porque tiene que haber un incentivo al lenguaje, el lenguaje atraviesa todo pero eso nadie se los planteó, nadie se los dijo y es normal. El chico sale [...] y ¿sabes qué? Menos diez [...] un chico no puede crecer si no tiene una familia".

De este relato se desprende que cuando las prácticas y representaciones sobre la crianza aparecen diferentes a los sentidos hegemónicos se las invisibiliza a través de justificar la explicación en términos de "parámetros culturales" ineficientes, antes que, como bien señala Colangelo (2014), a tradiciones ancestrales o bien a condiciones de vida de los sectores pobres.

¿Cómo entender los diferentes modos de crianza sin caer en un paternalismo condescendiente? ¿Cómo distinguir los diferentes modos de la crianza sin tener en cuenta la desigualdad social y sin dejar de respetar la diversidad de tradiciones presentes en los “otros”? ¿Cómo evitar caer relativismos culturales que nos lleven a 
desconocer que algunas prácticas no son por "elecciones" culturales, sino producto de desigualdades económicas?

Es insostenible afirmar que en un contexto carcelario donde se destacan las desigualdades tanto materiales como simbólicas, tal como lo desarrollé en el capítulo 2, exista alguna posibilidad de "elección" en cuanto a las prácticas de crianza y construcción de subjetividad de los niños y niñas.

\subsection{Sumario}

Los debates generados en torno al ISN, en cuanto a la ambigüedad del término, quedaron evidenciados en los diferentes sentidos dados al término por los actores de la presente Unidad. De los diferentes sentidos otorgados al ISN en contexto de encierro se visibilizó la naturalización de categorías como la maternidad y la crianza que a lo largo del capítulo puse en discusión. He afirmado que la maternidad no se encuentra sujeta a un hecho natural sino que es el resultado de un proceso histórico económico y social. Como construcción social he concluido que aún en los contextos mas adversos las mujeres deben "encajar" en el molde en donde el mandato socio cultural las pone, para no caer en críticas moralizantes sobre su desempeño como madres. 


\section{CONSIDERACIONES FINALES}

La principal pregunta que guió mi investigación fue qué sentidos otorgaban al interés superior del niño/a en el encierro y al ejercicio de sus derechos, sus madres, el personal penitenciario, funcionarios judiciales y los docentes de la institución educativa a la que concurren. Ello también me conminó a analizar las representaciones que poseen sobre el encierro y el ejercicio de la maternidad los actores sociales arriba mencionados.

En ese sentido en el capítulo primero describí y analicé la estructura funcional y orgánica de la Unidad 33, sus relaciones con otras instituciones y los sentidos dados a la misma por los actores en escena, así como la finalidad del encierro. Vimos como dentro de estas instituciones donde se visibilizan relaciones de poder y resistencia analizada en términos de Foucault, la finalidad resocializadora se diluye en esa lógica en la que se encuentran hundidas las relaciones dadas entre los actores sociales. Asimismo puse en discusión cómo en dicho contexto se hacen presentes discriminaciones fundamentalmente de origen social y de género que evidencian que los fines "resocializadores" lejos de poder cumplir con su finalidad profundizan dicha dinámica trasladándose a los niños y niñas que acompañan a sus madres en dicho contexto. Para describir estas lógicas discriminatorias la categoría analítica “colectividades bivalentes" construida por Fraser (1997) me acompañó a lo largo de la investigación.

Es así como en el capítulo 2 describí los discursos y prácticas presentes en el paradigma del Patronato de Menores y en la Doctrina de la Protección Integral de los Niños y Niñas en donde la guía para dicho análisis fue la categoría analítica “colectividad bivalente”, más arriba nombrada. Esta observación visibilizó la tensión existente en los discursos y las prácticas demostrando que, si bien los discursos pueden servir como el inicio para instalar un debate en la agenda pública, los mismos deben ir acompañados de cambios arduos y profundos en las prácticas.

A su vez, demostré que los sentidos diferenciales que le otorgan los actores al "Interés Superior del Niño/a" generan que el mismo se convierta en un principio sujeto a la discrecionalidad de quien lo pone en práctica. El análisis a lo largo de esta investigación ha permitido sostener que los diferentes sentidos dados a dicho ISN se apoyan en estereotipos de infancia y de ejercicio de la maternidad que generan que se 
continúen llevando a cabo las mismas prácticas minorizantes que se quisieron dejar en el olvido con el tan esperado cambio de paradigma. En las situaciones de encierro de niños/as con sus madres señalé como cobra preponderancia el sistema patriarcal por sobre cualquier principio o garantía de los niños/as. Ello fue abordado en el capítulo tercero, en el que analicé la construcción de "buenas" y "malas" madres a través de los significados otorgados al ejercicio de la maternidad. Ello demostró que las representaciones sobre el ejercicio de la maternidad van acompañadas del imaginario colectivo de un ideario biologicista sobre las mujeres relacionadas con el rol materno.

El "mirar" y "escuchar" al que se refiere Cardoso de Oliveira (1994) o el “estar allí" de Geertz (1995), como actos cognitivos preliminares del trabajo de campo a través de la observación participante, de las entrevistas semi estructuradas y en profundidad, me permitió comprender, desde los viajes que realizaba hacia la Unidad penitenciaria hasta el ingreso y salida de la misma, cómo es vivido el encierro de los niños/as por los distintos actores involucrados (madres, encargadas del servicio penitenciario, profesionales del Consejo Asistido, operadores judiciales), poniendo en evidencia los diferentes sentidos dados a dicho encierro. Todo ello me llevó a comprender que los modos en que las mujeres ejercen su rol materno dentro de la cárcel se encuentra inevitablemente inscripto en la dinámica de las relaciones de poder que se establecen en dicho contexto.

Las prácticas minorizantes no han cesado. Los menores de ayer siguen siendo los niños pobres de hoy. El arraigado sistema penal unido al arraigado sistema patriarcal hace que el interés suprior del niño se desvanezca entre los dos sistemas.

Frente a una Institución en la que no sólo vigila y evalúa el comportamiento de las mujeres detenidas sino también el comportamiento en su rol materno, tendremos que seguir debatiendo y visibilizando prácticas que lejos de adecuarse al ejercicio de derechos conforme los estándares establecidos en los tratados internacionales, reproducen los discursos de un sistema patriarcal que se intenta dejar atrás.

Aquel interés superior del niño/a presentado por la comunidad internacional como invencible encontró su "talón de Aquiles" en el interés de "la sociedad" por obtener la tan buscada y ansiada "seguridad". Seguridad que en apariencia se logra aislando por un tiempo determinado a aquel/lla que generó la "inseguridad", arrastrando 
en el caso de las mujeres a sus hijos/as, proporcionándose un "tratamiento" que se reduce a prácticas sintetizadas en talleres. La pregunta inevitable que sigue es si ese cumplimiento satisface las necesidades de alguien, de quiénes, y si eso es suficiente o necesario. La lectura lineal de la ley escrita en un tiempo determinado, que poco o nada tiene que ver con la realidad y con lo que se espera de ese difuso sentido que es el tratamiento, genera que las mujeres se "acomoden" y resignifiquen sus prácticas en función de lo que se espera de ellas: buenas mujeres madres. 


\section{BIBLIOGRAFIA}

ARIÈS, P. ([1960] 1987). “El descubrimiento de la infancia” En: EI niño y la vida familiar en el Antiguo Régimen. Madrid, Taurus.

BADINTER, E. (1981). ¿Existe el amor maternal? Historia del amor maternal. Siglos XVII al XX. Barcelona, Paidós/Pomaire.

BELOFF, M. (1999). "Protección integral de los derechos del niño y de la situación irregular: un modelo para armar y otro para desarmar" En: Justicia y Derechos del Niño $n^{o} 1$, pp. 9-21.

(2005). “Constitución y derechos del niño". En: Estudios

sobre Justicia Penal (separata) Homenaje al Profesor Julio B.J.Maier. Buenos Aires, Editores del Puerto.

(2003). "Un fallo tardío pero dichoso. (Comentario a la sentencia I.2278 "Procurador General de la Suprema Corte de Justicia v. Provincia de Buenos Aires. Inconstitucionalidad Ley 12.607. Acción de inconstitucionalidad”)". En: Revista de Derecho de Familia, 2003-I. Buenos Aires, ed. Lexis-Nexis, pp. 72-93.

(2008). "Quince años de vigencia de la Convención sobre los Derechos del niño en la Argentina" En: Justicia y Derechos del Niño nº 10, pp. 1144.

BIRGIN, H. (2000). "Prólogo". En: BIRGIN, H. (comp.) Las trampas del poder punitivo. El género del dereho penal. Buenos Aires, Biblos.

BOURDIEU, P. (1990). “Algunas propiedades de los campos". En: Sociología y cultura. México, Grijalbo.

(1997). "El espíritu de familia”. En: Razones prácticas.

Sobre la teoría de la acción, Barcelona, Anagrama.

BUTLER, J. (1990). El género en disputa: El feminismo y la subversión de la identidad. Barcelona-Buenos Aires-Mexico, Paidós. 
CAIMARI, L. (2007). "Entre la celda y el hogar. Dilemas estatales del castigo femenino (Buenos Aires, 1890-1940) En: Nueva Doctrina Penal, 2007/A, pp. 427-450.

CARDOSO de OLIVEIRA, R. (1996). "0 trabalho do antrop6logo: olhar, ouvir, escrever". Em: Revista de antropologia. São Paulo; USP, 1.996, V. $39 \mathrm{n}^{\circ} 1$, pp.13-37.

CARLI, S. (2006). "Notas para pensar la infancia en la Argentina (19832001). Figuras de la historia reciente" En: La cuestión de la infancia. Entre la escuela, la calle y el shoping. Buenos Aires, Paidós.

---------- (s.f.). La infancia como construcción social. En: http://blogs.unlp.edu.ar/pec/files/2016/04/Carli-La-infancia-como-construcciónsocial.pdf

CILLERO BRUÑOL, M. (1999). "El interés superior del niño en el marco de la Convención Internacional sobre los Derechos del Niño" En: Justicia y Derechos del Niño ${ }^{0} 1$, pp. 45-62.

COLANGELO, M. (2014). La crianza como proceso sociocultural. Posibles aportes de la antropología al abordaje médico de la niñez. Primeras Jornadas Diversidad en la Niñez. Hospital El Dique, Ensenada (Buenos Aires).

"La mirada antropológica sobre la infancia". Mesa temática sobre "Infancias y juventudes. Pedagogía y formación”, Seminario Internacional "La Formación Docente entre el siglo XIX y el siglo XXI", Ministerio de Educación, Ciencia y Tecnología de la Nación- Organización de Estados Iberoamericanos, Buenos Aires, 28 y 29 de noviembre de 2003. Publicado en formato virtual en http://www.mcye.gob.ar/curriform/publica/oei_20031128/ponencia_colangelo.pdf

COLLIER, J.; ROSALDO M. y YANAGISAKO S. (1997). "Is there a Family? New Anthropological Views". En: LANCASTER, J. \& di LEONARDO, M. (comps.). "The gender sexuality reader". London; Routledge (Traducción: Sofía Tiscornia). 
de SOUSA SANTOS, B. (2002). "Hacia una concepción multicultural de los derechos humanos." Traducción Libardo José Ariza, En: El otro derecho, número 28. Colombia. ILSA, Bogotá D.C.

DAROQUI, A. y GUEMUREMAN, S. (1999). "Los < menores> de hoy, de ayer y de siempre: un recorrido histórico desde una perspectiva crítica", En: Delito y Sociedad. Revista de Ciencias Sociales, No 13.

DIKER, G. (2009). ¿Qué hay de nuevo en las nuevas infancias? Buenos Aires, Los Polvorines, Universidad Nacional de General Sarmiento.

FERNANDEZ BLANCO, C. (s.f.). "Los principios desde el principio" En: Temas claves en materia de Protección y Promoción de Derechos de niños, niñas y adolescentes en la Provincia de Buenos Aires. Buenos Aires.

FOUCAULT, M. (1988) "El sujeto y el poder”. En: Revista Mexicana de Sociología, Vol. 50, No. 3. (Jul. - Sep.).

(1989). Vigilar y Castigar. Nacimiento de la prisión. Argentina, Siglo XXI.

FRASER, N. (1997). Iustitia Interrupta: Reflexiones críticas desde la posición "postsocialista", Santa Fé de Bogotá, Siglo del Hombre Editores.

FREEDMAN, D. (2005). "Funciones normativas del interés superior del niño" Publicado en formato en http://www.juragentium.org/topics/latina/es/freedman.htm

GEERTZ, C. (1995). La Interpretación de las Culturas; Barcelona, Gedisa.

GOFFMAN, E. (1992). Internados: Ensayos sobre la situación social de 1os enfermos mentales. Buenos Aires; Amorrortu.

GRASSI, E. (1999). “La Familia: Un objeto polémico. Cambios en la dinámica de la vida familiar y cambio de orden social." En: NEUFELD, M.; 
TISCORNIA, S. y WALLACE, S. (comps.) Antropología social y política. Hegemonía y poder: el mundo en movimiento, Buenos Aires, Eudeba, pp. 95-119.

GROSMAN, C. (1993). "Significado de la Convención de los Derechos del Niño en las relaciones de familia.” En: La ley 1993-D, 1089.

GUBER, R. (s.f.). El Salvaje metropolitano. Reconstrucción del conocimiento social en el trabajo de campo. Paidós Estudios de Comunicación.

(2001). La etnografía. Método, campo y reflexividad.

Bogotá, Grupo Editorial Norma.

HERRERA FLORES, J. (2008). La reinvención de los derechos humanos. Andalucía, Atrapasueños.

JENKS, C. (1996). Childhood. London and New York, Routledge.

MEAD, M. (1990). Adolescencia y Cultura en Samoa. Barcelona, Buenos Aires, México, Paidós.

MORA, A. (2010). “Cuerpos, sujetos, corporalidades, Subjetividades”. En: Mora, Ana S. El cuerpo en la danza desde la antropología. Prácticas, representaciones y experiencias durante la formación en danzas clásicas, danza contemporánea y expresión corporal. Tesis doctoral inédita. Facultad de Ciencias Naturales y Museo, Universidad Nacional de La Plata.

NAREDO MORELO, M. (2012). “Reclusas con hijos/as en la cárcel” En: $V$ LEX. En: https://app.vlex.com/\#vid/441850, pp. 263-275.

NARI, M. (2004). Políticas de maternidad y maternalismo político, Buenos Aires, Biblos.

ORTNER, S. (2009). "Resistencia densa: muerte y construcción cultural de agencia en el montañismo himalayo". En: Papeles de trabajo. Año 2, no 5 . Revista electrónica del Instituto de Altos Estudios Sociales de la Universidad Nacional de General San Martín, Buenos Aires. 
OTANO, G. (2000). "La mujer y el derecho penal. Una mirada de género"; En: BIRGIN, H. (comp) Las trampas del poder punitivo. El género del derecho penal. Buenos Aires, Biblos.

PLATT, A. (2001). Los "salvadores del niño", México, Siglo XXI.

RIFIOTIS, T. (2014). "Entre Teoria, Estética e Moral. Lugares da Antropologia na produção da justiça. En: Antropologia em Primeira Mão. Programa de Pós-graduação em Antropologia Social, UFSC (141)1-24.

RIFIOTIS, T. y CASTELNUOVO N. (2011). "La "violencia" como punto de partida” En: RIFIOTIS y CASTELNUOVO (comps.) Antropología, violencia y justicia. Repensando matrices de la sociabilidad contemporánea en el campo del género y de la familia. Buenos Aires, Antropofagia.

RIVERA BEIRAS, I. (1997). "Lineamientos garantistas para una transformación radical y reduccionista de la cárcel, una visión desde España. Problemáticas detectadas en el sistema penal español.” En: http://perso.unifr.ch/derechopenal/assets/files/articulos/a_20120608 03.pdf

SCHNEIDER, D. (1972). "What is kinship all about?" in: Reining, P. (org.) Kinship Studies in the Morgan Centennial Year. Washington, Anthropolological Society of Washington.

SZULC, A. (2006). Antropología y niñez: de la omisión a las "culturas infantiles”. En WILDE, G. y SCHAMBER, P. (Comps). Culturas, comunidades y procesos urbanos contemporáneos. Buenos Aires, SB, pp. 25-50.

TAUSSIG, M. (1995). "Maleficium: el fetichismo del Estado". En: Un gigante en convulsiones. El mundo humano como sistema nervioso en emergencia permanente. Barcelona, Gedisa.

VILLALTA, C. (2013). "Un campo de investigación. Las técnicas de gestión y los dispositivos jurídico-burocráticos destinados a la infancia pobre en la Argentina" En: “Civitas", Porto Alegre, V. 13, $\mathrm{N}^{\mathrm{o}}$ 2, maio-ago. En http://www.aacademica.org/carla.villalta/53 
WACQWANT, L. (2004). Las Cárceles de la Miseria, Buenos Aires, Manantial.

ZAFFARONI, E. (2000). "El discurso feminista y el poder punitivo" En: BIRGIN, H. (comp) Las trampas del poder punitivo. El género del Derecho Penal. Editorial Biblos; Buenos Aires.

ZAPIOLA, M. (2010). "La Ley de Patronato de Menores de 1919: ¿una bisagra histórica?" En: LIONETTI, L. y MÍGUEZ, D. (comps.), Las infancias en la historia argentina. Intersecciones entre prácticas, discursos e instituciones (18901960). Buenos Aires, Prohistoria.

\section{Informes}

Comisión Provincial por la Memoria (2014) Patear la reja. Género, encierro y acceso a la justicia: mujeres encarceladas con sus hijos en la Provincia de Buenos Aires. 